UNIVERSIDADE DE SÃO PAULO

FACULDADE DE FILOSOFIA, CIÊNCIAS E LETRAS DE RIBEIRÃO PRETO DEPARTAMENTO DE EDUCAÇÃO, INFORMAÇÃO E COMUNICAÇÃO

PROGRAMA DE PÓS-GRADUAÇÃO EM EDUCAÇÃO

DILSON RUFINO DA SILVA

JOVENS E O FAZER TEATRAL: CONTRIBUIÇÕES DE UMA EXPERIÊNCIA DE EDUCAÇÃO NÃO ESCOLAR EM TEATRO AOS SEUS PROCESSOS DE SOCIALIZAÇÃO E AUTONOMIA 
DILSON RUFINO DA SILVA

\title{
JOVENS E O FAZER TEATRAL: CONTRIBUIÇÕES DE UMA EXPERIÊNCIA DE EDUCAÇÃO NÃO ESCOLAR EM TEATRO AOS SEUS PROCESSOS DE SOCIALIZAÇÃO AUTONOMIA
}

\begin{abstract}
Dissertação apresentada ao Programa de PósGraduação em Educação do Departamento de Educação, Informação e Comunicação da Faculdade de Filosofia, Ciências e Letras de Ribeirão Preto da Universidade de São Paulo como parte das exigências para a obtenção do título de Mestre em Ciências.
\end{abstract}

Orientador: Prof. Dr. Elmir de Almeida

Versão corrigida. 
Autorizo a reprodução e divulgação total ou parcial deste trabalho, por qualquer meio convencional ou eletrônico, para fins de estudo e pesquisa, desde que citada a fonte.

Silva, Dilson Rufino

Jovens e o fazer teatral: contribuições de uma experiência de educação não escolar em teatro aos seus processos de socialização e autonomia. Ribeirão Preto, 2016.

$127 \mathrm{p}$.

Dissertação de Mestrado, apresentada à Faculdade de Filosofia Ciências e Letras de Ribeirão Preto/USP. Programa de Pósgraduação em Educação.

Orientador: Almeida, Elmir de.

1.Jovens. 2.Educação não Escolar. 3. Fazer teatral. 


\section{AGRADECIMENTOS}

Ao Elmir, pela confiança, orientação e aprendizados. Sou muito grato.

Aos colegas que de maneira direta ou indireta auxiliaram na concretização desse trabalho, entre eles Beatriz, Mariana, Tiago, Gisele, Rosana e outros quem compartilhei experiências nas salas da FFCLRP ou UFSCAR.

Aos jovens e educadores participantes dessa pesquisa, que se mostraram abertos e confiantes ao apoiarem minha iniciativa.

A toda minha família, em especial à Patrícia, pelo carinho apoio e paciência.

Aos professores Geraldo Romanelli, Marcus Vinicius, Débora Piotto, Fernando Donizete, entre outros, que suportaram minhas tantas dúvidas com paciência e atenção.

Aos fazedores de teatro, aos educadores que me auxiliaram em outras etapas da minha vida, e aos colegas da Associação Cultural Opereta, na cidade onde nasci e onde tudo começou. 
$A$ arte pode levar o homem de um estado de fragmentação a um estado de ser íntegro, total. A arte capacita o homem para compreender a realidade e o ajuda não só a suportá-la, como a transformá-la, aumentando-lhe a determinação de torná-la mais humana e mais hospitaleira para a humanidade. A arte, ela própria, é uma realidade social.

(Ernst Fischer- A necessidade da Arte) 


\section{RESUMO}

O trabalho apresenta resultados da pesquisa de mestrado, na qual investigou-se a respeito das contribuições do fazer teatral (educação não escolar) à socialização, independência e autonomia de jovens entre 17 e 29 anos, em um curso de teatro oferecido por organização não governamental inserida em espacialidade urbana da região do nordeste do estado de São Paulo. No estudo, de natureza qualitativa, predominaram a observação livre e a realização de entrevistas de tipo "compreensiva". Aportes teóricos das áreas das Ciências Sociais, das Artes/Teatro e da Educação orientaram todas as fases da pesquisa, em especial a compreensão das experiências individuais, sociais e culturais dos jovens. Os resultados apontam que o engajamento dos jovens diversifica e adensa seus processos socializadores e permite-lhes construir uma "visão de mundo" e tecer um "mundo" diverso de seus familiares, grupos religiosos, escolares, entre outros, constituindo-se em uma prática educativa que vai além da transmissão de técnicas, saberes e conhecimentos próprios da linguagem teatral.

Palavras-chave: Jovens. Fazer teatral. Educação não escolar. 


\begin{abstract}
This paper presents results of research that focuses on the contributions of the theatrical creative process to the socialization, individualization and autonomy of young people in educational spaces outside of formal schooling. The study focuses on young people, aged between 17 and 29, who attend introductory theater classes in a non-governamental organization located at a urban spaciality in the northeastern region of the State of São Paulo. The study is based on qualitative data grounded on contributions from the areas of Social Sciences, Theater and Education. In field works were adopted methodological procedures as direct observation, the recording in a field diary, and the realization of "reflective interview." The results suggest that experience increases the diversification of socialization processes, autonomy and individuation of the young people and shows to be an educational practice that goes beyond the transmission techniques, own knowledge of theatrical language.
\end{abstract}

Keywords: Young People. Theatrical process.Non-scholarly education. 


\section{SUMÁRIO}

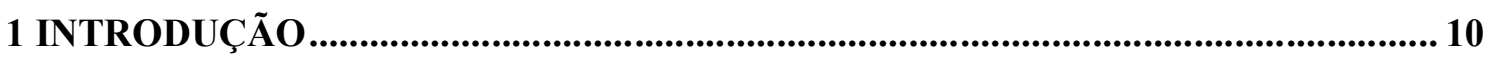

1.1 Aportes teóricos e procedimentos metodológicos adotados na pesquisa ..................... 13

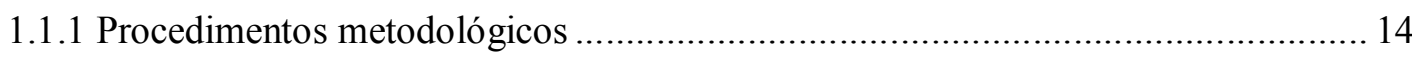

1.1.2 Resultados atingidos em diferentes etapas do estudo ........................................ 15

1.1.2.1 Levantamento, seleção e leitura de trabalhos pós-graduados sobre juventude, jovens,

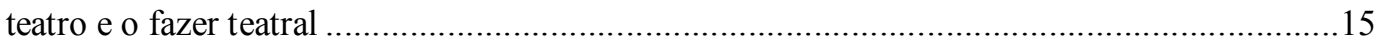

1.1.2.2 Atividades visando a constituição do campo empírico e os sujeitos da pesquisa ...........18

1.1.2.2.1 A escola e o curso de formação em teatro em Ribeirão Preto..................................18

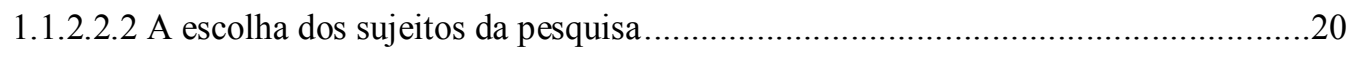

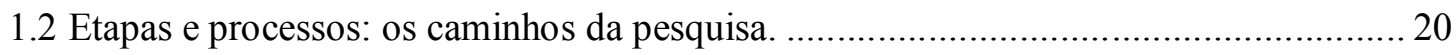

1.3 Condições de realização das entrevistas e degravação ............................................. 21

2 JUVENTUDE, JOVENS, SOCIALIZAÇÃO E EDUCAÇÃO NÃO ESCOLAR .......... 23

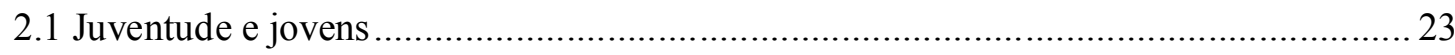

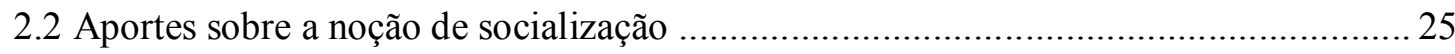

2.2.1 O desafio de ser jovem na contemporaneidade: entre socializações, independência e

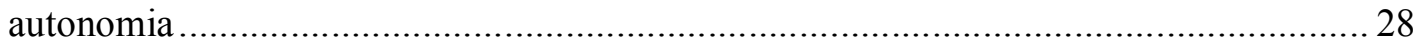

2.3 Juventude, jovens, educação escolar e educação não escolar ...................................... 30

2.4 Contribuições da formação teatral aos processos de socialização dos jovens ................ 34

2.4.1 O teatro, o fazer teatral e a importância do jogo para a educação do indivíduo ....... 37

2.4.2 Contribuições cognitivas - linguagem e pensamento......................................... 40

2.4.3 A questão do corpo: autoconhecimento e exploração das potencialidades............. 41

\section{O INSTITUTO RIBEIRÃO EM CENA, SUA PROPOSTA DE EDUCAÇÃO NÃO} ESCOLAR EM TEATRO E OS JOVENS PARTICIPANTES DA PESQUISA............ 43

3.1 O Instituto Ribeirão em Cena - IRC: elementos sobre origens da organização ............. 44

3.1.1 A “missão" do IRC: inclusão e formação profissional por intermédio do curso de

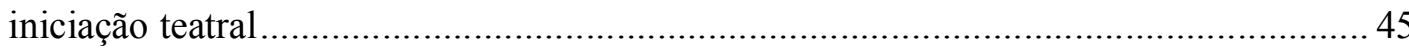

3.1.2 Organização temporal e proposta curricular do curso de iniciação teatral do IRC: educação não formal em forma escolar.................................................................... 45

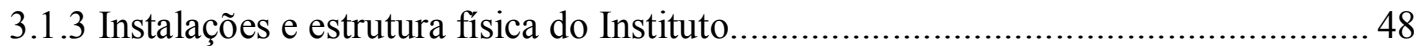

3.1.4 Sociabilidades construídas no cotidiano do Curso de Iniciação do IRC ................. 49

3.2 Retratos dos sujeitos que colaboraram com a investigação ....................................... 52 
3.2.1 Andrei, 17 anos, branco. Nasceu e mora em Cravinhos....................................... 53

3.2.2 Vânia, 18 anos, branca. Nasceu e mora em Ribeirão Preto.................................. 55

3.2.3 Igor, 18 anos, branco. Nasceu e mora em Ribeirão Preto. …............................... 55

3.2.4 Natália, 18 anos, branca. Nasceu e mora em Ribeirão Preto ................................ 57

3.2.5 Nádia, 27 anos, branca. Nasceu e mora em Ribeirão Preto.................................. 59

3.2.6 Nicolas, 17 anos, pardo. Nasceu e mora em Ribeirão Preto................................. 61

3.2.7 Marina, 29 anos, branca. Nasceu e mora em Ribeirão Preto.................................. 62

3.2.8 Ivan, 17 anos, negro. Nasceu e mora em Serra Azul. ........................................ 63

3.2.9 Alexander, 19 anos, negro. Nasceu e mora em Ribeirão Preto. ............................. 64

3.2.10 Sofia, 21 anos, branca. Nasceu e mora em Ribeirão Preto................................. 65

3.2.11 Olga, 20 anos, branca. Nasceu em Porto Velho. Mora em Ribeirão Preto ........... 67

3.2.12 Lucas, 17 anos, branco. Nasceu e mora em Ribeirão Preto ................................... 68

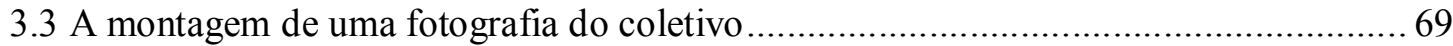

\section{OS JOVENS E O CURSO DE TEATRO DO IRC: ENFRENTAMENTOS,} CONTRIBUIÇÕES E PLANOS DE FUTURO .................................................... 72

4.1 Os jovens e o fazer teatral: tensões, resistências e incentivos com/de membros da família

4.2 Contribuições do fazer teatral aos processos de socialização e de autonomia dos jovens

4.2.1 O curso de formação teatral e o "conhecimento de si" ....................................... 78

4.2.2 Capacidades de expressar opinião e tomada de "posições no espaço público"....... 81

4.2.3 O fazer teatral, a autoaceitação da orientação sexual e o pertencimento étnico-racial. 83

4.2.4 O corpo dos jovens, angústias, a busca de identidade e contribuições do fazer teatral

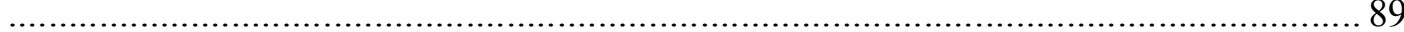

4.3 Jovens, o fazer teatral e seus planos futuros de trabalho .......................................... 93

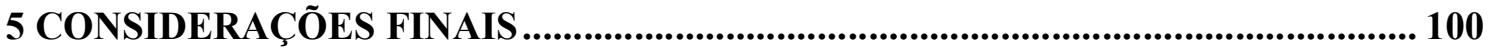

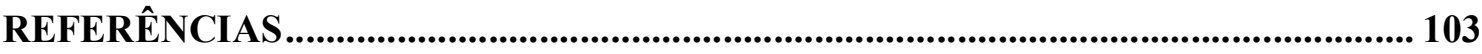

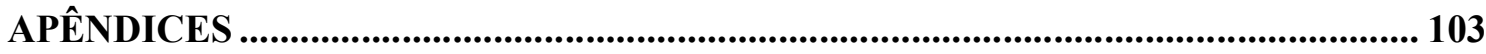

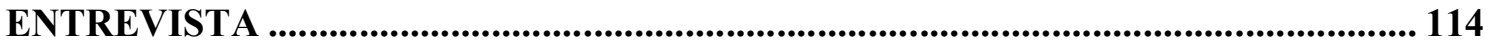




\section{INTRODUÇÃO}

O projeto de pesquisa que permitiu a elaboração deste texto dissertativo foi gestado durante aulas que frequentei na disciplina Jovens, Participação e Espaço Público, no âmbito do programa de Pós-Graduação em Educação, na Faculdade de Filosofia, Ciências e Letras da USP de Ribeirão Preto.

Frequentar as aulas daquela disciplina foi fundamental, pois, por meio dos aportes teóricos ali obtidos - em especial os relacionados à sociologia da educação escolar e não escolar, e também sobre a juventude e os jovens, posteriormente, aprofundados por leituras e discussões realizadas de obras da área da Sociologia que se voltam àquelas temáticas, no âmbito do grupo de estudo do LEPINJE - Laboratório de Estudos e Pesquisa sobre Infância, Juventude e Educação, pude delimitar de forma mais precisa as questões que desenvolvi entre 2013 e 2015

Ao inscrever-me na disciplina acima mencionada, o que me motivara era o desejo de compreender os processos educativos nos quais os jovens se envolvem e que se concretizam em espaços não escolares, denominados por alguns pesquisadores como não-formais (REYMOND, 2003; GOHN, 2008) ou não-escolares (SPOSITO, 2008), e que estavam particularmente vinculados à minha formação anterior nas áreas do teatro e da pedagogia do teatro. A partir dos debates desenvolvidos naquela Disciplina, deparei-me com uma área educacional que apresenta muitos desafios em sua compreensão, mas que potencialmente contribui à ampliação dos capitais cultural e social de indivíduos de diferentes idades do curso da vida (BOURDIEU, 1998).

As inquietações que deram origem a essa pesquisa remontam, também, aos percursos de socialização e educação que vivenciei, e das interações que estabeleci em organização não governamental $^{1}$ em que fui educando a partir dos 17 anos de idade e, posteriormente, fui educador voluntário em teatro, por volta dos 20 , um período que proporcionou-me diferentes contribuições em termos de formação pessoal e profissional em minha juventude.

Trago como lembrança dos primeiros encontros como participante das oficinas de teatro no interior dessa entidade a seguinte imagem: jovens e indivíduos não tão jovens assim, descalços, sentados, em roda conversava,trocávamos impressões sobre vários assuntos; alguns jovens, alguns deles trabalhadores como eu,chegávamos, tirávamos o uniforme e vestíamos o que se convencionou chamar de "roupa de guerra", geralmente roupas já um pouco

\footnotetext{
${ }^{1}$ Associação Cultural Opereta - Organização Não Governamental de caráter cultural localizada na cidade de Poá-SP
} 
"surradas", com as quais se podia ter um pouco mais de liberdade de movimentos, como deitar-se no chão, rolar, e fazer múltiplos e diferenciados tipos de exercícios corporais. Eu, que era jovem, estudante e trabalhador, encontrei-me assumindo uma nova atividade, uma experiência de trabalho no campo da educação não escolar e das artes.

Naquele espaço, sob a coordenação de uma companhia de teatro, vários processos socializadores e educativos se desencadeavam, se entrelaçavam, e enriqueciam nosso cotidiano: nos movimentos de improviso de adereços e figurinos, no manuseio de ferramentas; jovens que tinham o primeiro contato com informática auxiliavam a "planilhar" os livros da biblioteca comunitária. Tudo foi ganhando seu ritmo e se acertando. No mesmo espaço, em pouco tempo, além da turma do teatro, havia outras, de música, de dança e afins, surgidas do sonho de um grupo de teatro.

Dessas experiências juvenis guardo duas recordações primordiais, a experiência de aprender e ensinar e a sensação de pertencimento a algum tipo de universo social e cultural: o do teatro e do fazer teatral.

Aqueles encontros e seus processos formativos foram vitais para que eu escolhesse assim que me foi possível - uma carreira de formação universitária na área da Educação Artística, com habilitação em Artes Cênicas. O curso foi realizado em instituição superior da rede particular, com o suporte de bolsa de estudo do PROUNI - Programa Universidade para Todos.

$\mathrm{Na}$ Universidade, eu estava imerso em mais um espaço de interações e socialização secundária (BERGER \& LUCKMANN, 1997), adensando meus processos de independência, autonomia e individuação, pois me inseri em novo contexto de normas institucionais, de sociabilidades, de educação, de formação profissional, os quais enriqueciam minhas concepções de mundo, de cultura, de artes, de realização e consumo das artes em geral.

Ser jovem, trabalhador, estudante e cuidar da casa, para aqueles que já tinham seu lar, exigia estratégias diversificadas para se manterem na Faculdade, se organizarem e cumprissem com a realização dos trabalhos bem como com os prazos de entrega das atividades exigidas. Muitas vezes, tive que reinventar maneiras de estudar para aos seminários e encenações dramatúrgicas, entre as ferramentas da ocupação manual que exercia à época chaves de fendas, alicates, componentes eletrônicos, entre outros.

Naquele contexto socializador e educativo, percebia que a cada obra de teatro lida e discutida em classe, eu me apropriava de saberes sobre as épocas em que foram escritas, visões de mundo que elas explicitavam, mais ainda, acessava conhecimentos sobre geografia, história, psicologia, sociologia e política, dessa maneira, ampliava e enriquecia meu repertório 
de conhecimento e saberes. Em cada jogo, em cada exercício prático que desenvolvia, em cada movimento do corpo que realizava, fortalecia meu processo identitário e de individuação, reconhecia meus limites e buscava apoios e suportes por superá-los (FABBRINI \& MELUCCI, 1992; MARTUCCELLI, 2012). Na sala de aula, nos desafios do trabalho em grupo, nos pudores e medos da exposição, nas opiniões divergentes e às vezes antagônicas, os desafios de conviver com as diferenças, com a alteridade, do autoconhecimento e da construção mais autônoma de uma visão de mundo e de como agir no mundo.

Assim, já naquela época, minha hipótese era a de que o conhecimento e os valores morais, éticos e estéticos propiciados pelo teatro iam além das técnicas e saberes artísticos relativos às artes da cena. Percepção essa que foi ampliada na formação complementar que realizei, posteriormente à titulação em Educação Artística, frequentando dois cursos de pósgraduação lato sensu: um deles referente à Pedagogia do Teatro e da Dança, na Universidade Sagrado Coração e outro, denominado Apontamentos Conceituais sobre o Teatro de Rua, oferecido pela UNESP- São Paulo. Nesses espaços educativos entrei em contato com noções que ampliavam a possibilidade de pesquisa , por exemplo, no curso sobre o Teatro de Rua, os temas e questões abordadas tinham relações com direito à cidade, às territorialidades citadinas, a dimensão pública do espaço urbano, analisados a partir de autores das áreas das Ciências Sociais (Michel de Certeau, Raymond Williams e Jacques Le Goff) e da Filosofia (Mikhail Bakhtin), do Teatro e do fazer teatral (Augusto Boal), de modo a compreender a cidadania e a realidade da cidade, do urbano, suas ruas e as disputas por tais territórios por diferentes atores sociais situados no espaço público.Também encontrei nas disciplinas cursadas na Pedagogia do Teatro indícios da importância do teatro para o autoconhecimento e identidade.

O conjunto de elementos apresentados anteriormente revela os percursos que contribuíram para delinear os questionamentos da investigação que deu origem a esta dissertação, isto é, pesquisar sobre o que a arte, especificamente a teatral, proporciona aos jovens do ponto de vista socializador e educativo sem, contudo, limitar-se às dinâmicas e aos aspectos propriamente técnicos dessa modalidade artística, dessa prática cultural. Meu intento foi o de investigar as contribuições do teatro e do fazer teatral para a experiência humana, sobretudo as experiências humanas e sociais daqueles que se encontram na fase da juventude. Assim, encontrei na Sociologia as noções de socialização e autonomia e elas serviram de ponto de partida para que pudesse definir a pergunta central de minha pesquisa com os seguintes contornos: que contribuições atividades educativas de natureza não escolar na área 
do fazer teatral podem oferecer aos processos de socialização, independência e autonomia de

jovens - homens e mulheres - que com elas se envolvem na atualidade?

Ao buscar respostas às duas questões principais do estudo proposto, os objetivos específicos da pesquisa foram os de:

- Compreender os sentidos atribuídos pelos jovens às práticas formativas em teatro, realizadas em espaço de educação não escolar;

- contribuir para a produção de conhecimento sobre os processos de socialização de jovens no âmbito da educação não escolar;

- apreender indícios dos processos de autonomia e individuação de jovens envolvidos com experiência do fazer teatral, nas circunstâncias históricas e sociais em que estão imersos.

\subsection{Aportes teóricos e procedimentos metodológicos adotados na pesquisa}

A pesquisa situou-se no campo de estudos de juventude e dos jovens brasileiros e suas relações com propostas de educação não escolar na chave do fazer teatral. Nas diferentes etapas da investigação adotou-se obras de autores/pesquisadores das Ciências Sociais e Humanas, das Artes, do Teatro e do Fazer Teatral, tais como:

1) os resultados do estado da arte de estudo sobre juventude nas áreas da Educação, das Ciências Sociais e Sociais Aplicadas (SPOSITO, 2009);

2) textos que versam sobre Teatro e a formação teatral (SLADE, 1978; HUIZINGA, 1980; LOPES, 1989; BOAL, 2002; COURTNEY, 2003; DESGRANGES, 2011);

3) trabalhos sobre educação não formal ou não escolar (REYMOND, 2003; BROUGÈRE \& BÉZILLE, 2007; GOHN, 2006; 2008; SPOSITO, 2008);

4) estudos da Sociologia que se voltam à análise da juventude e dos jovens na contemporaneidade (ATTIAS-DONFUT, 1996; BOURDIEU, 1978,1997,1998,2002 ; PAIS, 1990; FABBRINNI \& MELUCCI 1992; DE LEON, 2005);

5) obras da Sociologia que abordam os temas da a) socialização (BERGER \& LUCKMANN, 1974; MARTUCCELI, 2012; SINGLY, 2005; SETTON; 20), b) autonomia (SINGLY, 2004; 2005; MARTUCCELLI, 2007) e c) individuação (SINGLY, 2004, 2005; MARTUCCELLI, 2007; 2012), entre outros. 


\subsubsection{Procedimentos metodológicos}

À busca de respostas à pergunta central da investigação proposta, e tendo em vista o conjunto de abordagens e procedimentos metodológicos possíveis de serem adotados no âmbito da pesquisa educacional (MAZZOTTI, 2001; ANDRÉ, 2001) ${ }^{2}$, percorreu-se os seguintes caminhos:

1. o levantamento, seleção e leitura de trabalhos pós-graduados brasileiros - dissertações e teses - com temas semelhantes ao de minha investigação, elaborados nas áreas da Educação e das Ciências Sociais - Sociologia e Antropologia; 2)

2. escolha de coletivo ou organização da sociedade civil de Ribeirão Preto que fosse representativo do conjunto de iniciativas de formação do fazer teatral e desenvolvesse trabalho educativo também com adolescentes e jovens;

3. observação direta e livre, registro em diário de campo de elementos concernentes às interações, atividades e práticas realizadas pelos sujeitos pesquisados no contexto de um "um micro processo" social (MARTINS, 2004) de educação não escolar na área da formação teatral;

4. realização de entrevistas com os jovens, homens e mulheres, com idades entre dezessete (17) e vinte e nove (29) anos de idade, participantes de curso de formação teatral a mais de doze (12) meses, e que se dispusessem a colaborar com a pesquisa.

No âmbito da pesquisa qualitativa, há um conjunto diverso de tipos de entrevistas possíveis de serem utilizados para empreender com os sujeitos centrais da investigação. Assim tem-se a entrevista não diretiva, semi diretiva, semi estruturada, estruturada, biográficas, reflexiva, entre outras (SZYMANSKI; 2002; GOMES, 2008; DELORYMOMBERGER, 2012; FERREIRA, 2014). Tendo em vista os objetivos e a indagação principal do estudo realizado, adotou-se com proposta de interação e diálogo com os sujeitos jovens a entrevista de tipo "compreensivo", que, segundo Ferreira (2014):

trata-se de uma técnica qualitativa de recolha de dados que articula formas tradicionais de entrevista semidiretiva com técnicas de entrevista de natureza mais etnográfica, na tentativa de evitar quer o dirigismo do modelo de questionário aberto, quer o laissez-faire da entrevista não diretiva. (FERREIRA, 2014, p. 981).

Ainda de acordo com Ferreira (2014), esse tipo de entrevista implica

\footnotetext{
${ }^{2} \mathrm{O}$ projeto inicial de pesquisa foi avaliado e aprovado pelo Comitê de Ética da FFCLRP. No início das atividades de campo, solicitou-se autorização expressa aos responsáveis pelo Instituto Ribeirão em Cena - IRC de maneira a realizar o conjunto das atividades de campo.
} 
um saber-fazer mais pessoal do que estandardizado, decorrente do próprio envolvimento do investigador no desenvolvimento da pesquisa num terreno concreto, havendo, contudo, lugar a um grau de formalização e de sistematização mais elevado que as técnicas etnográficas de recolha de informação. Promotora de uma lógica de criatividade e de descoberta científica fundadora de novas teorias e conceitos, mais do que uma lógica de demonstração e ilustração de teorias previamente construídas, a entrevista compreensiva procura produzir novas preposições teóricas, através de uma articulação estreita e contínua entre o processo de recolha de dados e o processo de formulação de hipóteses. Estas serão tanto mais criativas quanto enraizadas nos dados recolhidos. Uma formulação bottom up, portanto, que deriva de baixo para cima, do terreno empírico para o terreno teórico, até formalizar o que se convencionou chamar de grounded theory, nas suas formulações mais antigas. (Id, 2014, p. 981-2).

Deste modo, a pesquisa desenvolvida foi de abordagem qualitativa que toma as "unidades sociais investigadas como totalidades", e demandam do pesquisador "um exame intensivo dos dados, tanto em amplitude quanto em profundidade", de maneira a estabelecer "a estreita aproximação dos dados, de fazê-lo falar da forma mais completa possível, abrindose à realidade social para melhor apreendê-la e compreendê-la." (MARTINS, 2004, p.292).

\subsubsection{Resultados atingidos em diferentes etapas do estudo}

1.1.2.1 Levantamento, seleção e leitura de trabalhos pós-graduados sobre juventude, jovens, teatro e ofazer teatral

No início dos anos 2.000, ao criticar os resultados alcançados pela pesquisa educacional, Mazzotti (2001) afirmou que muitos dos estudos desenvolvidos naquela área pareciam desconsiderar que a produção do conhecimento científico é fruto de processo coletivo, pois envolve variados atores, situados em diferentes espaços e tempos, e vinculados a diferentes áreas do conhecimento. De acordo com a pesquisadora, muitos dos trabalhos por ela avaliados deixava uma forte impressão que os autores partilham de um certo "narcisismo investigativo", pois

um indicador bastante concreto disso [era] a despreocupação, cada vez maior, nos projetos e relatórios de pesquisa, de situar o problema proposto no contexto mais amplo da discussão acadêmica sobre o tema focalizado. Isso se verifica tanto pela falta de uma introdução que proporcione um "pano de fundo" às questões focalizadas quanto pela ausência de comparação entre os resultados obtidos e aqueles originados por outros estudos relacionados ao tema, ou, ainda, entre os resultados e as implicações de alguma teoria. (MAZZOTTI, 2001, p. 42). 
Ao ter em conta as críticas de Mazzotti (2001), uma das primeiras atividades desenvolvidas na pesquisa foi a de buscar e selecionar estudos pós-graduados - dissertações e teses, elaborados na área da Educação ou outras áreas do conhecimento científico, que abordassem tema ou questões similares ou próximos à por mim delimitadas. Deste modo 1) li resultados do estado da arte de estudos brasileiros pós-graduados sobre juventude, realizados no período 1999-2006, nas áreas da Educação, Ciências Sociais e Serviço Social, coordenado Sposito $(2009)^{3}$ e 2) efetuei buscas no Banco de teses e dissertações do Portal Capes/MEC e na Biblioteca Digital do Sistema Dedalus da Universidade de São Paulo - USP, considerando o período de 2007 e 2014.

A investigação de Sposito (2009) identificou que entre 1999 e 2006 foram produzidos 4.413 trabalhos dedicados à análise de vinte e seis (26) temáticas sobre a juventude e experiências de jovens brasileiros. Embora os resultados desse balanço tenham evidenciado um relativo crescimento de dissertações e teses no campo dos estudos de juventude no início da década de 2.000 , eles também tornaram clara a existência de reduzido número de trabalhos voltados à apreensão e análise das relações entre os jovens brasileiros e as artes, sobretudo na área da Educação.

Ao percorrer-se os capítulos dos dois volumes daquele "estado da arte", o que se constatou foi que as dissertações e teses analisadas e que se aproximaram das interações entre os jovens e práticas artístico-culturais o fizeram a partir de indagações que focaram as culturas ou determinadas "formações associativas" juvenis envolvidas, por exemplo, com o rock, o heavy metal, o rap, a música eletrônica dançante, o forró sertanejo ou forró universitário, o manguebeat, o grafite, o break, a culture jamming, o role playing, as HQs histórias em quadrinhos etc.(ALMEIDA, 2009). Porém, não foram analisadas dissertações e teses que tivessem se dedicado especificamente às relações dos jovens e o teatro ou os jovens e o fazer teatral.

Por outro lado, os resultados da pesquisa de Sposito (2009) proporcionaram um conjunto de referências de conceituais sobre as categorias juventude e jovens, assim como serviram-me de parâmetro para empreender buscas a fim de identificar e selecionar outros estudos do campo da juventude que tivessem relações com o teatro e o fazer teatral, tanto na Banco de Teses da Capes/MEC como na Biblioteca Digital do Sistema Dedalus USP, realizados no período de 2007-2014.

\footnotetext{
${ }^{3}$ Segundo Sposito (2009): "Os trabalhos foram selecionados a partir das informações contidas no Banco de Teses do portal CAPES", e para tanto foram considerados quarenta e três (43) descritores (id : p. 13).
} 
Nestas bases de dados, as buscas foram realizadas usando-se quatorze (14) descritores ${ }^{4}$, mas não se usou filtros quanto as áreas do conhecimento científico, pois importava mais identificar dissertações e teses que tivessem se voltado a investigação dos temas interligados juventude, jovens e teatro ou juventude, jovens e formação teatral ou fazer teatral.

No Banco de Teses da CAPES foram localizadas nove (9) produções $^{5}$ diferentes áreas do conhecimento ${ }^{6}$ que exploraram as relações entre jovens e teatro ou atividade teatral, a partir de diferentes questões e perspectivas teóricas, tal como disposto no Quadro 1 e Apêndice 1).

Daquele reduzido conjunto de trabalhos, apenas duas (2) produções foram desenvolvidas na área da Educação, mas não tiveram os jovens como sujeitos centrais de investigação. O primeiro estudo visou compreender o teatro como prática artístico-educativa com potencial de artístico-educativo capaz de incitar "a reflexão crítica" de forma a levar "uma comunidade escolar" a "compreender cada vez melhor suas situações-limites e se mobilizar para superá-las" (SAUL, 2011); a segunda pesquisa, de perspectiva etnográfica, foi dedicada ao estudo e análise de "pistas de uma Educação-Sensível" que elegeu como mediação a "Pedagogia do Teatro" como um “saber e saber fazer"”; o campo empírico foi uma "Escola do Presídio" do Interior do Estado de São Paulo e os informantes"da investigação foram "'monitores culturais' detentos". A investigação "privilegiou as imagens, os espaços e as narrativas como possibilidades de evidenciar pistas de uma educação sensível a partir de uma experiência artístico-pedagógica", de maneira a "produzir um conhecimento a partir do não-racional, dos sentimentos, das emoções, das paixões, das tragédias, dos sentimentos e da ludicidade" (GOMES, 2012).

No ambiente virtual da Biblioteca Digital da USP foi possível constatar que entre 2007 e 2014 foram incorporadas 38.433 dissertações e teses, porém aquela base não continha registros de produções discentes que constassem, em seus títulos ou resumos, os termos juventude/jovem(ns) e teatro, juventude/jovem(ns)e formação teatral ou juventudeljovem(ns) e fazer teatral. A mesma situação se verificou quando alterou-se aqueles descritores para os de adolescente/adolescência. Diante de tais situações, fez-se a busca de trabalhos usando-se somente os termos juventude/jovem(ns); com tais filtros foram localizadas cento e quarenta e seis (146) dissertações e teses (cf. Tabela I, Anexo III).

\footnotetext{
${ }^{4}$ Foram eles: teatro; formação teatral; adolescentes e teatro; jovens e teatro, adolescência e teatro; juventude e teatro; adolescência e formação teatral; juventude e formação teatral; adolescente e formação teatral; jovens e formação teatral; adolescente/adolescência e fazer teatral e jovem/juventude e fazer teatral.

${ }^{5}$ Uma (1) tese e oito (8) dissertações.

${ }^{6}$ Artes; Artes Cênicas; Artes e Cultura Visual; Educação;Ensino de Biociências;História; Medicina e Teatro.
} 
Daquele subconjunto de produções (146) que exploraram algum aspecto ou dimensão da vida juvenil ou dos jovens brasileiros e suas diferentes práticas sociais, quarenta e sete (47) delas foram elaboradas na área da Educação, sendo que delas, apenas a tese de Villar e Villar (2007)e a dissertação de Vilutis (2009) tinham pontos de conexão com o tema, questões e sujeitos de minha investigação No primeiro caso, a pesquisadora focalizou as experiências de doze (12) jovens, moradores de cidades do Grande ABC (SP), que se envolveram com atividades formativas na área do Teatro oferecidas pela EMIA - Escola Municipal de Iniciação Artística de Santo André (cinco jovens), e com as "oficinas de artes circenses" mantidas pela Prefeitura de São Bernardo do Campo (sete jovens) (VILLAR E VILLAR, 2007). Já a investigação de Vilutis (2009) voltou-se à análise da "relação entre acesso à cultura, o processo pedagógico de formação de jovens" e as vias que eles tomavam para inserirem-se na "comunidade". Os sujeitos dessa pesquisa foram dezessete (17) jovens que participaram de processo formativo denominado "Agente de Cultura Viva" oferecido em dois distintos "Pontos de Cultura" situados na Zona Leste da cidade São Paulo.

A partir dos resultados descritos acima, pode-se dizer que os estudos de Villar e Villar (2007), Vilutis (2009), Saul (2011) e Gomes (2012) se dedicaram ao estudo de sujeitos jovens e adultos envolvidos com práticas culturais que envolviam processos educativos não escolares

- formação teatral, artes circenses, teatro, pedagogia do teatro, concebidas e oferecidas por instituições públicas estatais, porém os problemas de pesquisas delimitados pelas duas pesquisadoras foram distintos dos que circunscrevi para estudar a juventude e as experiências de jovens, no campo da pesquisa educacional.

Assim, a partir do balanço de Sposito (2009), dos levantamentos realizados nas bases de dados da CAPES/MEC e da Biblioteca Digital da USP, é possível considerar que é reduzido o número de pesquisas pós-graduadas realizadas, entre 1999-2014, na área da Educação, escolar ou não escolar, que tenham se preocupado com a compreensão das contribuições que cursos no campo do fazer teatral oferecem aos processos de socialização, independência e autonomia dos jovens brasileiros na atualidade.

\subsubsection{Atividades visando a constituição do campo empírico e os sujeitos da pesquisa}

\subsection{A escola e o curso de formação em teatro em Ribeirão Preto}

Em Ribeirão Preto, tanto o governo municipal (Almeida \& Pires, 2010; Vinha, 2014) como organizações privadas e instituições públicas há mais de uma década têm formatado e 
oferecido à crianças, jovens e adultos da localidade processos educativos,de natureza não escolar, nas áreas das artes cênicas, incluindo o fazer teatral.

Exemplos de iniciativas educativas de formação teatral - com diferentes níveis de aprofundamento e perspectivas teóricas e artísticas, oferecidas por organizações ou atores do setor privado seriam as do SESI (Curso de Livre de Iniciação Teatral) ${ }^{7}$, do SENAC (Oficina de Teatro e Curso Técnico de Teatro) ${ }^{8}$, do Teatro Popular de Comédia (Iniciação e Avançado) ${ }^{9}$, a Cia Minaz (estudos em Dramaturgia da Imagem) ${ }^{10}$, o Teatro Santarosa (Curso Livre de Teatro) ${ }^{11}$, o Projeto Kabuki, entre outros.

$\mathrm{Na}$ cidade, ofertas públicas estatais de formação teatral podem ser identificas com as oficinas de teatro oferecidas pela Administração Municipal ${ }^{12}$, e o Núcleo TUSP - Teatro da Universidade de São Paulo e seu trabalho de "experimentação do fazer teatral".13

Mas entre iniciativas educativas públicas e do setor privado no campo do fazer teatral na localidade, há uma que surgiu em 2001 a partir experiências ocorridas no interior do tecido social da cidade, nomeada como Instituto Ribeirão em Cena - IRC, que ganhou reconhecimento como organização cultural não governamental que se dedica ao fomento do Teatro e ao oferecimento gratuito de curso de iniciação teatral a jovens de adultos de Ribeirão Preto e região.

Tendo em conta as diferentes propostas educativas do fazer teatral mencionadas anteriormente e dada as especificidades históricas que marcaram o surgimento e o enraizamento do IRC na dinâmica social e cultural de Ribeirão Preto ${ }^{14}$ quanto ao oferecimento de curso iniciação teatral a adolescentes, jovens e adultos visando a inclusão social e a formação para a cidadania, tomou-se a decisão de escolher aquela experiência educativa e cultural como território de pesquisa educacional na chave da educação não escolar. Tal decisão também tomou por referência o fato de que o curso do IRC tem duração de dois (2) anos é oferecido gratuitamente a indivíduos de diferentes idades do curso da vida, nos períodos matutino, vespertino e noturno.

\footnotetext{
${ }^{7}$ Disponível em: <http://www.sesisp.org.br/noticias/sesi-sp-abre-inscricoes-para-cursos-gratuitos-de-iniciacaoem-artes-cenicas-em-1-de-julho>. Acesso em: dez. 2014 e maio 2016.

${ }^{8} \mathrm{O}$ Curso Técnico de Teatro oferecido pelo SENAC é estruturado numa perspectiva escolar. Disponível em: $<$ https://www.sp.senac.br/jsp/default.jsp?newsID=DYNAMIC,oracle.br.dataservers.CourseDataServer,selectCou rse\&course $=43 \&$ template $=380$.dwt\&unit $=$ NONE\&testeira $=474>$. Acesso em: dez. 2014 e maio 2016.

${ }^{9}$ Disponível em: <http://www.teatrotpc.com.br/site/cursos/index/id/4>. Acesso em: dez. 2014 e maio 2016.

${ }^{10}$ Disponível em: <http://www.minaz.com.br/\#!nossos-cursos/146ni> . Acesso em: maio 2016.

${ }^{11}$ Disponível em: $<$ http://teatrosantarosa.com.br/cursos/>. Acesso em: maio 2016.

${ }^{12}$ Disponível em: <http://www.ribeiraopreto.sp.gov.br/scultura/palace/i14oficinas.php. Acesso em: maio 2016.

${ }^{13}$ Disponível em: <http://tuspribeirao.blogspot.com.br/p/nucleo-tusp.html>. Acesso em: dez. 2014 e maio 2016.

${ }^{14}$ As especificidades históricas e sociais que marcaram o nascimento do IRC na cidade, assim como sua proposta educativa, serão aprofundadas no Capítulo II.
} 


\subsection{A escolha dos sujeitos da pesquisa}

A partir das questões do estudo, e considerando o contexto espacial e educativo IRC, definiu-se que as interações e diálogos se dariam com doze jovens - seis mulheres e seis homens, com idades entre 17 e 29 anos de idade, que frequentassem a proposta educativa do Instituto há mais de doze meses, nos períodos matutino, vespertino ou noturno. O propósito de estabelecer diálogos com jovens mulheres e homens levou em conta possíveis diferenciais de socialização dos gêneros, tanto nos percursos socializadores prévios ao ingresso dos mesmos no Instituto como decorrentes do processo de socialização e educação vivenciado no curso do IRC.

A partir dos critérios citados acima - idade, sexo, e tempo de engajamento no curso, a escolha dos jovens ocorreu de forma aleatória e a partir do aceite de cada um deles em contribuir com o estudo. ${ }^{15}$

\subsection{Etapas e processos: os caminhos da pesquisa.}

A primeira etapa da pesquisa ocorreu no segundo semestre de 2013 quando foram realizadas as leituras que auxiliaram na escolha do IRC, foram estabelecidos os primeiros contatos com os coordenadores do Instituto e os jovens envolvidos com o curso de iniciação teatral, e a elaboração do roteiro da entrevista de tipo "compreensivo" (FERREIRA, 2014).

Nos primeiros meses de 2014 deu-se o início das atividades de observação direta e livre - com registros em diário de campo - das experiências educativas, culturais e lúdicas vividas pelos jovens no IRC. Ainda no primeiro semestre de 2014 foram realizadas cinco (5) entrevistas com dois (2) homens e três (3) mulheres.

No início de 2015, após a leitura, sistematização e análise das informações e dados fornecidos pelos cinco (5) jovens, seguiu-se o exame de qualificação, momento em pude contar com as observações críticas e sugestões dos integrantes da comissão julgadora para o retorno das atividades de campo.

Nos demais meses de 2015, dediquei à ampliação e aprofundamento de leituras que pudessem contribuir para o aprimoramento do roteiro da entrevista, a realização das demais entrevistas - sete (7), com cinco (4) homens e três (3) mulheres.

\footnotetext{
${ }^{15}$ No capítulo II apresentaremos de modo mais detalhado as características demográficas e socioculturais dos doze (12) jovens que colaboraram com a pesquisa.
} 


\subsection{Condições de realização das entrevistas e degravação}

As entrevistas deram-se em sua maioria no próprio Instituto ou em salas da Universidade de onde realizo a pesquisa. Sempre foram respeitadas as sugestões dos jovens, sendo que em alguns casos o ruído foi motivo de mudança do local. A preferência dos jovens por serem entrevistados no Instituto, local de grande circulação de pessoas, fez com que em comum acordo tivéssemos que caminhar até uma praça próxima ao IRC, ou até uma sorveteria nos arredores. O tempo de gravação dos diálogos variou entre quarenta (40) a sessenta (80) minutos, somando o total de (8) horas e trinta (30) minutos de conversações, narrativas e reflexões.

Com cada jovem, realizou-se apenas uma entrevista, todavia, contatos com eles foram mantidos posteriormente de forma a esclarecer incompreensões ou dúvida que tivemos na leitura das narrativas, e também para complementar dados ou informações julgadas necessárias e pertinentes à caracterização de cada um deles. $\mathrm{O}$ áudio foi captado em formato mp3 por um gravador portátil, e teve qualidade satisfatória, pois foi testado a cada local diferente com cada jovem, antes de cada entrevista. O processo de transcrição foi demorado, sobretudo por ser experiência inédita ao pesquisador, sendo interrompido quando não havia mais condições de concentração devido ao cansaço e retomado posteriormente. Após cada entrevista, anotei quando julguei necessário alguma expressão física que pudesse complementar algo que havia sido dito, e durante a degravação recorri a essas anotações. Nesse momento houve uma contradição entre a satisfação em ouvir a voz gravada dos jovens felizes em colaborar com a pesquisa, lembrar das suas expressões e gestos, e o aborrecimento e a morosidade do processo de digitação das falas, que parecia não ter fim. Em média, cada hora de entrevista rendeu-me três horas e meia de digitação realizada com algumas pausas para descanso. Outro fator de ordem pessoal: ocorreu que à época do exame de qualificação sofri uma queda e fraturei o braço, o que de certa forma impactou no rendimento da minha digitação que ocorreu durante a minha recuperação.

Com os percursos explicitados acima e resultados acumulados nas diferentes etapas da investigação, foi possível elaborar o presente texto dissertativo.

No capítulo II apresento os aportes teóricos, advindos das áreas da Sociologia, da Educação e do Teatro, que serviram de sustentação aos trabalhos de campo, à sistematização e à análise das narrativas formuladas pelos jovens e à redação do presente texto.

O capítulo III foi dedicado à descrição do campo empírico da pesquisa - o Instituto Ribeirão em Cena - IRC - sua estrutura física, os componentes de sua proposta educativa, e a 
descrição de certas sociabilidades observadas em seus diferentes espaços e tempos. Nessa Seção, ainda, apresentou-se os retratos de cada um dos jovens que colaboram com a investigação, caracterizando a partir de dados e sociodemográficos, socioculturais e de elementos de suas famílias de origem. Na continuidade, descrevemos os percursos socializadores que contribuíram para que os jovens optassem pelo curso em teatro do IRC como processo socializador e educativo de natureza não escolar.

Foram apresentadas e analisadas no capítulo III as contribuições que o curso do IRC ofereceu aos processos socializadores e de autonomia dos jovens estudados e apontamos sobre os planos que eles formularam para o futuro profissional, considerando a passagem que fizeram por aquela proposta educativa de natureza teatral.

Nas considerações finais, tem-se uma breve reflexão sobre os achados da investigação e se eles responderam as questões centrais que serviu de ponto de partida à pesquisa desenvolvida. 


\section{JUVENTUDE, JOVENS, SOCIALIZAÇÃO E EDUCAÇÃO NÃO ESCOLAR}

O mundo não é. O mundo está sendo. Como subjetividade curiosa, inteligente, interferidora na objetividade com que dialeticamente me relaciono, meu papel no mundo não é só o de quem constata o que ocorre, mas também o de quem intervém como sujeito de ocorrências. Não sou apenas objeto da História, mas seu sujeito igualmente.

Paulo Freire ${ }^{16}$

Conforme afirmado na introdução a presente pesquisa teve como temas centrais as contribuições que o curso de Iniciação teatral desenvolvido pelo Instituto Ribeirão em Cena (IRC), ofereceram aos planos socializadores e de autonomia de jovens em Ribeirão Preto.

Em todas as etapas da investigação as noções de jovens, juventude, socialização, do fazer teatral e autonomia foram compreendidas e utilizadas a partir de contribuições extraídas do pensamento sociológico que se voltaram aos referidos temas, e de suas interações com contextos e processos socializadores de educação não escolar na área do fazer teatral na contemporaneidade.

Por tais razões, nesta sessão, apresentamos os modos como nos apropriamos daquelas noções no estudo realizados.

\subsection{Juventude e jovens}

Os temas da juventude e dos jovens têm sido abordados por diferentes autores das Ciências Sociais, situados nos contextos latino-americano, norte-americano e europeu, com distintas preocupações e perspectivas teórico-metodológicas. Uma das advertências que contribui com nossos passos nesta pesquisa, nós a encontramos em trabalho de Claudine Attias-Donfut (1996), quando a pesquisadora chama nossa atenção para uma tarefa que devemos empreender nos estudos sobre a juventude e jovens, ou seja, precisamos distinguir claramente os termos juventude e jovens. Lembra a pesquisadora que a juventude pode ser entendida a partir de dois sentidos "semanticamente distintos": "geração" e "fase da vida", já os jovens devem ser entendidos com os "seres concretos, "situados historicamente", que vivem aquela "etapa da vida", etapa que é por definição "transitória" (ATTIAS-DONFUT, 1996, p.13; tradução livre).

Às advertências de Attias-Donfut (1996) é possível adicionar as observações de Pierre Bourdieu (2002), quando destaca as dimensões relacionais e políticas (lutas pelo poder e pela

\footnotetext{
${ }^{16}$ Pedagogia da autonomia: saberes necessários à prática educativa , 1997. p 30
} 
divisão do poder) presentes na construção social da juventude e dos sujeitos concretos que a vivem, pois as fases da vida são construções socioculturais, estruturadas em meio a disputas pelo poder e a partilha do poder, "entre jovens e velhos". Recorda o sociólogo que:

esta estrutura, que é encontrada em outros lugares - por exemplo, nas relações entre os sexos, lembra que a divisão lógica entre os jovens e os velhos, trata-se de poder. As classificações por idade (mas também por sexo ou, claro, entre as classes...) sempre impõem limites e produzem uma ordem onde cada um deve se manter, onde cada um deve permanecer em seu lugar. (BOURDIEU, 2002, p. 143, tradução livre).

Além do mais Bourdieu (2002) ressalta que podemos incorrer em "formidável abuso de linguagem" ao subsumir sob uma mesma noção - a juventude, “jovens das diferentes frações da classe dominante" e "jovens que já se encontram no universo do trabalho", pois coexistem "entre estas posições extremas, o estudante burguês e, do outro lado, o jovem operário que nem mesmo tem adolescência". Lembra o pesquisador que é o fato de apreendermos os jovens concretos, situados em diferentes situações e posições sociais, é que nos permite avaliar a complexidade inerente a esta fase da vida, assim como nos autoriza a falar “juventudes”, diferentes “juventudes (BOURDIEU, 2002, p. 143, tradução livre).

Com as contribuições de Attias-Donfut (1996) e de Bourdieu (2002) no que aprendemos e buscamos considerar no estudo é que a noção de juventude não é imediatamente redutível à de jovens: a primeira pode ser entendida como "fase" ou "etapa" da vida e "envolve elementos históricos e contextos socioculturais específicos e diversificados (SPOSITO, 2008, p. 95); por outro lado, a noção de jovens tem por referência concreta uma unidade empírica, o "ser", a "pessoa" ou o "indivíduo", que vive um tempo histórico preciso, ocupa uma posição social na estrutura socioeconômica, tem pertencimento etário, sexual, étnico-racial, pode acessar ou não os direitos de cidadania e humanos.

Anna Fabbrini \& Alberto Melucci (1992), ancorados numa perspectiva fenomenológica, enriqueceram nosso repertório em termos de compreensão da juventude e dos jovens, pois para esses autores a juventude seria um tempo em que os indivíduos têm o respaldo social para se dedicarem à formação, à exploração de oportunidades, à experimentação de trajetos, à reversão das escolhas que formulam; ela seria também o tempo em que os indivíduos vivem de modo crucial os sonhos e as experiências do medo e da crise. Dessa forma, tal "estação" seria decisiva no curso da vida, pois é nela que, pela primeira vez, o indivíduo afirma "quem ele é", ao mesmo tempo em que nutre a esperança de que o(s) outro(s) confirme(m) o que ele afirma sobre si. 
Em virtude das situações e condições acima, Fabbrini e Melucci (1992) entendem que a adolescência e a juventude podem ser consideradas como uma "idade de ouro": a estação da vida na qual "estão concentradas as articulações mais significativas da experiência humana: o drama da escolha, a necessidade de mudar, o medo de fazê-lo" (FABBRINI; MELUCCI, 1992, p. 8); um período ou uma estação da vida que passa, mas fica - e não como "patologia" ou "desajuste", fica como reminiscência, pois "sua memória e seu rastro prolongam-se nas grandes etapas da existência, como um eco vívido continuamente re-despertado" (FABBRINI; MELUCCI, 1992, p. 7) ${ }^{17}$.

Fabbrinni \& Melucci (1992) nos desafiam a compreender a fase juvenil descartando os estereótipos, e nos interpelam a conhecer outras dimensões das vivências juvenis - individuais e coletivas. Para eles, se abandonarmos as ideias pré-concebidas sobre a vida juvenil e os jovens, nos depararemos com indivíduos "conscientes, [...] capazes de pensar, de observar, de ter ideias e projetos para o próprio futuro. [...] Inteligências desejosas de conhecer e de pôr-se a prova, $[\ldots]$ que querem crescer e entrar na experiência da vida, a procura de uma verdade sobre o mundo e sobre si mesmas" (FABBRINI \& MELUCCI, 1992, p. 10).

Os aportes conceituais acima foram fundamentais para compreendermos a juventude como fase da vida, estruturada em meio às relações de poder que se estabelecem entre velhos, adultos e jovens; contribuíram também para que pudéssemos entender que os jovens vivem a experiência juvenil a partir de posições sociais e pertencimentos múltiplos, e, por fim, permitiram que entendêssemos os jovens como atores sociais, na medida em que agem, escolhem e revertem as escolhas feitas. Isto significa entender que eles não são apenas resultantes das determinações e condições, de diferentes ordens, que marcam suas existências; eles são também aquilo que eles fazem com o que as determinações, as circunstâncias e o mundo adulto fizeram com eles. Como afirma Danilo Martuccelli (2012, p. 37, grifo nosso), “o ator é aquele que é capaz de modificar seu entorno" ${ }^{18}$.

\subsection{Aportes sobre a noção de socialização}

No âmbito da investigação realizada, de modo à melhor apreender as contribuições oferecidas por um plano formativo na área do fazer teatral aos processos de socialização e de autonomia de indivíduos que se encontravam na fase da juventude, tivemos que nos

\footnotetext{
${ }^{17}$ Tradução livre do texto publicado em italiano

${ }^{18}$ Esclarece, ainda, Martuccelli (2012, p. 37), que "esta definição [...] deixa em aberto a possibilidade de tomarse em conta a existência de atores que não humanos porque, obviamente, existem dispositivos técnicos que transformam o entorno".
} 
aproximar da noção de socialização, tal como foi formulada por determinados autores clássicos e contemporâneos, nos domínios da teoria social.

Émile Durkheim (2007), por exemplo, defende a ideia de que a socialização é todo processo educativo, metódico e intencional, dos novos integrantes da sociedade. Dessa forma o processo socializador seria a ação proposital exercida pelos adultos sobre os "imaturos" - ou aqueles que ainda não estão maduros para a vida social, visando a neles suscitar "um certo números de estados físicos, intelectuais e morais que lhe exigem a sociedade política no seu conjunto e o meio ao qual se destinam particularmente" (DURKHEIM, 2007, p. 53).

Essa formulação de um dos clássicos da Sociologia que sublinha a socialização como uma ação racional e necessária à formação e a integração dos mais novos ao meio em que estão inseridos, não deixa de ser reducionista na medida em que define o processo socializador como uma ação unilateral e de mão única, que vai dos adultos às crianças, aos adolescentes e jovens. Ela deixa na sombra a socialização ou os processos socializadores de natureza mais co-figurativa, que, no interior de qualquer meio social, ocorre entre os iguais, e não deixa também de induzi-los a certos modos de agir, se comportar e pensar, tanto do ponto de vista físico como das perspectivas social e da adoção de valores morais.

Mais contemporaneamente, Peter Berger e Thomas Luckmann (1994) trouxeram reconhecidas contribuições à compreensão do processo de socialização dos mais novos. Esses sociólogos refinaram o conceito de socialização ao defini-la como sendo um processo que se divide em dois subtipos: a "socialização primária" e a "socialização secundária".

O primeiro subtipo eles definiram como sendo o processo "que o indivíduo experimenta na infância, e em virtude da qual torna-se membro da sociedade" (BERGER; LUCKMANN, 1944, p. 175). Já o segundo subtipo seria todo e qualquer processo posterior à socialização obtida nos círculos de relações primárias - a família, sobretudo, e que introduz um indivíduo já socializado em "novos setores do mundo objetivo de sua sociedade" (BERGER; LUCKMANN, 1944, p. 175), como o universo da educação escolar e o mundo do trabalho, por exemplo.

Danilo Martuccelli (2012), ao discorrer sobre as contribuições de Berger e Luckmann (1994), defende a ideia de que elas significaram um grande avanço analítico na "teoria da socialização", pois elas permitem entender e explicar que ao lado de uma socialização primária, pertinente aos anos iniciais da vida, e mediante a qual herdamos e consolidamos hábitos que nos acompanharão em outras fases do curso da vida, há "um conjunto diverso de socializações secundárias", possível de ser identificado, sobretudo 
nas sociedades altamente diferenciadas, como são as sociedades modernas, existe um grande número de socializações secundárias (aprendizagens de novos papéis sociais no mundo do trabalho, processos sequenciais de socialização escolar - o ingresso na universidade, novos códigos de conduta associados a uma mudança de bairro ou de grupo social e, também, a socialização induzida pelo matrimônio. (MARTUCCELLI, 2012, p. 73, tradução livre).

Além de estabelecer os fundamentos teóricos da necessidade de estudos mais pormenorizados sobre os indivíduos (juvenis ou não), Martuccelli (2012) enfatiza que a singularidade da noção de "socialização secundária" reside no fato dela tornar

claro que a socialização não é um processo unitário e com um ponto final, ao contrário, ele encerra uma sucessão de socializações secundárias, mediante o qual os atores, e cada ator, cruzam muitos círculos e grupos sociais. Somos um palimpsesto original e diferenciado de socializações secundárias. (MARTUCCELLI, 2012, p. 74, tradução livre, grifo nosso).

As constatações de Oscar Dávila de Leon (2005) reforçam a importância da “socialização secundária” para compreendermos as experiências socioculturais e políticas dos atores juvenis, pois:

na trajetória de socialização que vivenciam os jovens desde sua infầncia até a autonomia pessoal, eles vêem-se mergulhados simultaneamente a um semnúmero de contextos culturais e redes de relações pessoais preexistentes família, amigos, companheiros de curso, meios de comunicação, ideologias, partidos políticos, entre outras - dos quais selecionam e hierarquizam valores e ideais, estéticas e modas, formas de relacionamento ou convivência e vida, que contribuem para modelar seus pensamentos, sua sensibilidade e seus comportamentos. (DAVILLA, 2005, p. 15).

No estudo que empreendemos sobre a socialização e a socialização dos jovens, foram menos as contribuições de Durkheim (2007) e mais as de Berger e Luckmann (1994), Martuccelli (2012), De Leon (2005) e Setton $(2002,2010)$ que nos serviram como espécie de guia na compreensão e interação com os jovens do presente estudo. As posições dos últimos autores pareceram-nos mais adequadas para compreendermos os jovens que frequentam as atividades oferecidas no campo do fazer teatral pelo IRC, também para valorizarmos os múltiplos e diferenciados círculos de interações sociais, processos socializadores e laços de pertencimento ${ }^{19}$ que vivenciaram no contexto do curso de teatro do IRC.

\footnotetext{
${ }^{19}$ Neste texto, adotamos as sugestões de Santos (2012) sobre o tema pertencimento, e o compreendemos como uma "crença subjetiva na qual os indivíduos pensam em si mesmos como membros de uma coletividade em que compartilham valores, anseios e aspirações em um espaço-tempo comum em que implica comprometimento ativo com um projeto que vá ao encontro desses anseios" (SANTOS, 2012, p. 37).
} 


\subsubsection{O desafio de ser jovem na contemporaneidade: entre socializações, independência e autonomia}

No âmbito dos processos socializadores secundários que dão densidade e diversificam as vivências juvenis, podemos identificar também que, a partir das posições sociais que ocupam e sob as circunstâncias histórico-econômicas em que se encontram, os jovens se deparam e experimentam outros processos sociais, tais como os que dizem respeito à conquista da "independência" e da "autonomia" (SINGLY, 2004; 2005).

Ao discorrer sobre os desafios que enfrentam os jovens para tornarem-se indivíduos nas "sociedades avançadas", François de Singly $(2004 ; 2005)$ lembra-nos que no contexto da chamada "segunda modernidade" ${ }^{20}$ os indivíduos devem estar "individualizados", isto é, eles devem evidenciar o domínio de determinadas "competências "pessoais"”, sendo que três (3) delas se destacariam:

a primeira é a de [conquistarem] uma certa desfiliação necessária frente aos pais; a segunda consiste em conquistarem uma certa coerência entre duas dimensões do processo de individualização, a independência e a autonomia e [...] a terceira é a formação permanente do $\mathrm{Eu}$, imperativo contrário à concepção clássica da idade adulta. (SINGLY, 2005, p. 111, tradução livre; grifo nosso).

Segundo Singly (2004; 2005), ao reconhecermos os processos que vivem os jovens para se tornarem indivíduos nas sociedades avançadas, altamente diferenciadas, nos deparamos com o que ele chama de "especificidade da juventude na segunda modernidade" (SINGLY, 2005, p. 112), isto é, os jovens devem vivenciar: 1) uma "certa "desfiliação", um distanciamento da definição do eu como 'filho' ou 'filha' e [acessar o] direito ao inventário da herança e da transmissão" (2) alterações ou modulações em seus processos identitários e 3) a dissociação entre "independência" e "autonomia" (SINGLY, 2005, pp. 114; tradução livre).

O pesquisador explica-nos que utiliza as noções de "independência e "autonomia" referenciando-se em autores da "filosofia política" e da "sociologia construtivista". Assim, a primeira noção é entendida a partir da "concepção monadológica" de Leibniz ${ }^{21}$ segundo a qual

\footnotetext{
${ }^{20}$ Ao usar a noção de "segunda modernidade", Singly (2005) dialoga com as reflexões sociológicas de Anthony Giddens, The transformation of intimacy: sexuality, Love and eroticism in modern societies (1991), Ulrich Beck, La sociétédu risque (2001), Ulrich Beck \&Elisabeth Beck-Gernsheim, Individualism (2002 e de François de Singly, L'individualisme est unhumanisme (2005) (SINGLY, 2005, p. 111). Nas palavras do autor, a "segunda modernidade" tem como marco histórico os anos de $1960 \mathrm{em}$ diante, momento em que, livres dos freios ao individualismo, próprios da "primeira modernidade", os indivíduos devem demonstrar certas habilidades pessoais (SINGLY, 2005, p. 111, tradução livre).

${ }^{21}$ Gottfried W. Leibiniz (1946-1716). Nos termos do Diccionario de Filosofia de Brugger (1998): "no que toca a sua essência, a mónada é a portadora do sujeito primitivo simples e encerra em si mesma o ser substancial; é
} 
a "independência" é a capacidade que têm o indivíduo de "não ter que prestar contas a ninguém porque dispõe de recursos que permitem-lhe evoluir de forma independente". Já a noção de "autonomia" foi ancorada em proposições de $\mathrm{Kant}^{22}$ e formulações da sociologia construtivista $^{23}$ para explicar o exercício realizado pelo indivíduo de forma a "outorgar a si mesmo uma lei própria e uma visão de mundo ou um 'mundo"” (SINGLY, 2004, p. 261, tradução livre).

De posse daqueles dois operadores analíticos e da compreensão de suas diferenças conceituais, desde um ponto de vista filosófico, Singly $(2004 ; 2005)$ defende a ideia de que, nas sociedades altamente complexas e diferenciadas, a juventude pode ser entendida como:

o período da vida durante o qual se dissociam as duas dimensões da individualização [independência e autonomia]. Os jovens encontram-se em condições sociais e psicológicas que lhes permitem acessar a uma certa autonomia, sem dispor de recursos, especialmente econômicos, suficientes para serem independentes de seus pais [...] Os jovens podem dispor de uma certa autonomia sem serem independentes. (SINGLY, 2004, p. 261; tradução livre; grifo nosso).

Para alguns jovens de certos estratos sociais a conquista da permissão para dirigir veículos automotores figuraria como exemplo da conquista de certa independência e mobilidade espacial. Outro marcador da conquista de independência estaria relacionado com o acesso a uma "atividade assalariada ou profissional suficiente para assumir seus gastos" econômicos. Esta segunda condição constitui, em tese, "o elemento mais significativo para não depender de alguém" (SINGLY, 2004, p. 261; tradução livre). Enquanto os jovens forem dependentes, torna-se mais complexa a avaliação do que fazem com sua "herança familiar", na medida em isso que ainda se encontra, concretamente, a "ser definido" pelos laços de filiação e dependência econômica. Por outro lado, e de modo contrastante, se os jovens têm "acesso a recursos econômicos pessoais e relativamente estabilizados, eles podem pôr em prática o direito ao inventário e transformarem [...] a relação com seus pais em um vínculo menos 'herdado' e mais ‘eletivo' (SINGLY, 2004, p. 115).

Quanto à conquista da autonomia pelos atores juvenis, nos esclarece Singly (2004; 2005) que ela não oblitera a vida em comum com os pais, com os pares (em moradia compartilhada) ou com o cônjuge; todavia, uma condição se impõe: é preciso "sempre que seu(s) sócio(s) lhe(s) deixem a possibilidade de pôr em marcha o trabalho de apropriação

concebida como uma entidade de natureza psíquica e tem também o corpo como fundamento" (BRUGGER, 1998, p. 374, tradução livre).

${ }^{22}$ Imannuel Kant (1724-1804).

${ }^{23}$ Um balanço reflexivo sobre as "sociologias construtivistas" encontra-se na obra de Philippe Corcuff. As novas sociologias: construções da realidade social (2001). 
de regras e princípios"; pois as pessoas que vivem sós são as que "se convencem mais facilmente de que são 'autônomas', na medida em que a ausência de negociação é vivida como um indicador de autodeterminação. (SINGLY, 2005, p. 115; grifo nosso).

Ainda que o tema central do texto de François de Singly $(2004 ; 2005)$ sejam as "formas dos jovens terminarem ou não a juventude" na contemporaneidade, ou seja, seus trânsitos rumo à idade adulta, suas reflexões sobre processos socializadores, os modos como os jovens se "desfiliam" de seus pais e assumem a "herança" e os conteúdos da "transmissão", como eles experimentam a "dissociação" entre "independência" e "autonomia", nos auxiliaram a compreender as relações que os jovens de modo geral e os sujeitos juvenis deste estudo se engajam em experiências socializadoras de educação não escolar, pois, se no caso da educação escolar, em especial a educação básica, tanto no Norte como no Brasil, ela implica uma obrigatoriedade, o mesmo não podemos afirmar em relação à educação não escolar, pois, ela pressupõe "uma ação voluntária" dos indivíduos" (REYMOND, 2003, p. 10; SPOSITO, 2008, p. 88), situação que, em tese, poderia ser lida como um exercício de "autonomia" dos atores juvenis", nas circunstâncias históricas em que estão imersos.

\subsection{Juventude, jovens, educação escolar e educação não escolar}

$\mathrm{Na}$ ordem moderna, a escola e seu trabalho específico - a escolarização, configuramse espaços-tempos predominante de "socialização voluntária" e educação da criança e dos jovens, e constituíram-se em mediações fundamentais para a construção social e cultural da infância e da juventude, tal como enfatizaram, a partir de preocupações distintas, Philippe Ariès (1978) e Alberto Melucci (2001). Segundo o historiador:

A partir de um certo período [...], e, em todo caso de uma forma definitiva e imperativa a partir do fim do século XVII, uma mudança considerável alterou o estado de coisas que acabo de analisar. Podemos compreendê-la a partir de duas abordagens distintas. A escola substituiu a aprendizagem como meio de educação. Isso quer dizer que a criança deixou de ser misturada aos adultos e de aprender a vida diretamente, através do contato com eles. A despeito das muitas reticências e retardamentos, a criança foi separada dos adultos e mantida à distância numa espécie de quarentena, antes de ser solta no mundo. Essa quarentena foi a escola, o colégio. Começou então um longo processo de enclausuramento das crianças [...] que se estenderia até nossos dias, e ao qual se dá o nome de escolarização. (ARIÈS, 1986, p. 3).

Se em Ariès (1986) a escola é representada como uma espécie de "quarentena" e "enclausuramento" dos mais novos, "antes de serem soltos no mundo", é preciso também 
considerar que a partir da constituição histórica daquele universo social e de sua crescente expansão, sobretudo a partir do Século XIX, seu espaço-tempo tem contribuído para a formação de uma cultura específica, dotada de autonomia relativa, que deriva da "corrente de sociabilidades" que tem por atores centrais as crianças, os adolescentes e jovens (CÂNDIDO, 1964). A respeito, registrou Melucci (2001, p. 101):

a criação de um espaço de vida autônomo pelas classes de idade mais jovem se realiza com a escolarização de massa. É a escola de massa que viabiliza o acesso as funções adultas, prolongando o tempo de não trabalho; ela cria também as condições espaço-temporais para a agregação de uma identidade coletiva $^{24}$ definida pela necessidade dos modos de vida e linguagens próprias.

Se a escola e a escolarização de crianças e jovens se constituem em uma mediação social e cultural que antecederia a inserção e integração da criança o jovem na vida e espaços públicos - com suas características especificas, tais como o anonimato, as regras morais marcadas pela a impessoalidade e racionalidade, precisamos considerar também que a escolarização não atua de forma isoladamente sobre aqueles indivíduos; a partir da ordem moderna, a escolarização ou "a socialização voluntária" das novas gerações coexistem e convivem com outras possibilidades educativas, tal como nos lembra Carlos Rodrigues Brandão (1982, p. 9):

existe a educação de cada categoria de sujeitos de um povo; ela existe em cada povo, ou entre povos que se encontram. Existe entre povos que submetem e dominam outros povos, usando a educação como um recurso a mais de sua dominância. Da família à comunidade, a educação existe difusa em todos os mundos sociais, entre as incontáveis práticas dos mistérios do

\footnotetext{
${ }^{24}$ Sobre os grupos e agregados adolescentes e juvenis que emergem no interior da escola, em especial a partir da expansão da escola secundária no hemisfério Norte, em meados do Século XX, Sposito (2003) lembra-nos das análises de um clássico sociólogo estrutural-funcionalista norte-americano, Talcott Parsons sobre as "culturas juvenis" que surgem no interior da escola: "Já na década de 50, com a disseminação do acesso à escola secundária formou-se uma cultura juvenil (os teenagers) amplamente marcada pelas formas de sociabilidade decorrentes do acesso ao ensino médio (high school). Parsons (1974) talvez seja uma das expressões mais importantes desse tipo de análise, pois, ao assumir o estatuto anômico da condição adolescente na sociedade nem criança e nem adulto -, considerava a experiência desses grupos como produto das tensões entre dois sistemas identificatórios: de um lado os valores da instituição escolar - a importância do estudo, a adesão aos processos de seleção inerentes às atividades escolares - e, de outro, os valores dos grupos de pares. Na gestão dessa ambivalência ocorreria o processo de socialização empreendido pela escola que, de modo global, não estaria ameaçado. Para alguns poucos, essa socialização da instituição fracassaria e eles transformariam os grupos de pares em mecanismos de fomentação de atividades delinquentes. Mas, para a maioria, essa subcultura juvenil no interior da escola seria eminentemente integradora, pois esses agrupamentos forneceriam fortes mecanismos de solidariedade e de organização das identidades, possibilitando a passagem da esfera privada da família, marcada pelas relações pessoais, para a esfera pública de caráter anônimo e impessoal. [...] Não só pelo tratamento funcionalista dos fenômenos sociais a crítica a Parsons foi feita, mas, também, nesse caso, porque, ao tomar a experiência típica de adolescentes e jovens de classe média, generalizou o alcance de sua explicação, sem considerar as diferenças que sempre marcaram a relação da escola a partir da condição de classe do seu público" (SPOSITO, 2003, p. 219).
} 
aprender; primeiro sem classes de alunos, sem livros e sem professores especialistas; mais adiante com escolas, salas, professores e métodos pedagógicos. [...] A educação pode existir livre e, entre todos, pode ser uma das maneiras que as pessoas criam para tornar comum, como saber, como idéia, como crença, aquilo que é comunitário como bem, como trabalho ou como vida. Ela pode existir imposta por um sistema centralizado de poder, que usa o saber e o controle sobre o saber A educação é, como outras, uma fração do modo de vida dos grupos sociais que a criam e recriam, entre tantas outras invenções de sua cultura, em sua sociedade. Formas de educação que produzem e praticam, para que elas reproduzam, entre todos os que ensinam-e-aprendem, o saber que atravessa as palavras da tribo, os códigos sociais de conduta, as regras do trabalho, os segredos da arte ou da religião, do artesanato ou da tecnologia que qualquer povo precisa para reinventar, todos os dias, a vida do grupo e a de cada um de seus sujeitos $[\ldots]$.

Às possibilidades de educação não identificadas com a escola e escolarização, destacadas por Brandão (1982), a literatura produzida nos campos da Sociologia e Educação as nomeiam como "educação informal", "não formal” ou "não escolar" (REYMOND, 2003; BROUGÈRE, BÉZILLE, 2007; GOHN, 2008; SPOSITO, 2008).

Maria da Glória Gohn (2008), por exemplo, propõe que entendamos a educação não forma como identificadas às práticas que derivam dos processos de compartilhamento de experiências, principalmente em espaços e ações coletivas cotidianas, nas quais o grande educador é o "outro", aquele com quem interagimos ou nos integramos. No âmbito da educação não formal, os espaços educativos localizam-se em territórios que acompanham as trajetórias de vida dos grupos e indivíduos, fora das escolas, em locais informais, locais onde há processos interativos intencionais ${ }^{25}$. Sua finalidade é abrir janelas de conhecimento sobre o mundo que circunda os indivíduos e suas relações sociais. Seus objetivos não são dados a priori, eles se constroem no processo interativo, gerando um processo educativo. Um modo de educar que surge como resultado do processo voltado para os interesses e as necessidades de quem dele participa. A transmissão de informação e formação política e sociocultural é uma meta na educação não formal etc. (GOHN, 2008, p. 29).

Por educação informal, aquela pesquisadora sugere que a compreendamos como sendo aquela prática, processos ou contextos nos quais os indivíduos aprendem durante seu processo de socialização - na família, bairro, clube, amigos etc., carregada de valores e culturas próprias, de pertencimento e sentimentos herdados: na educação informal, os agentes educadores são os pais, a família em geral, os amigos, os vizinhos, colegas de escola, a igreja paroquial, os meios de comunicação de massa, etc. A educação informal ocorrer continuamente, e em vários contextos, a casa onde se mora, a rua, o bairro, o condomínio, o

\footnotetext{
${ }^{25}$ Para Gohn (2008), a intencionalidade é importante elemento de diferenciação em relação à educação informal.
} 
clube que se frequenta, a igreja ou o local de culto a que se vincula sua crença religiosa, o local onde se nasceu, sem que haja clara intencionalidade e continuidade nesse processo educativo. (GOHN, 2008, p. 29).

Outra fonte sobre os significados da educação formal (escolar) e não formal, é o texto de Manoela Du Bois Reymond (2003), segundo a qual, há dois fatores que evidenciam as diferenças entre a educação formal e a educação não formal: no primeiro caso é necessário compreendermos que em muitas sociedades ela obrigatória, ao menos em certas etapas, e repousa sobre uma determinação e vontade extrínsecas aos indivíduos; no segundo caso, a determinação e a vontade são intrínsecas ao indivíduo, pois, até certo ponto, é ele quem decide se integrará ou não aos círculos, processos ou contextos de educação não formal. (REYMOND, 2003, p. 10) ${ }^{26}$.

Entretanto, Brougère e Bézille (2007) e Sposito (2008) observam que em diversos campos do conhecimento científico, no mundo das instituições e das organizações da sociedade civil, há "uma heterogeneidade conceitual e empírica significativa" sobre a educação não formal. Mas as afirmações de Sposito (2008) dialogam com as de Reymond (2003), ressaltando que, "ao menos por tradição" é possível identificar um traço comum nas definições correntes: elas "pressupõe a adesão voluntária do sujeito" (SPOSITO, 2008, p. 88).

No texto de Sposito (2008), encontramos outras contribuições sobre as possibilidades de apreensão da educação não formal e sobre a "vontade intrínseca" ou "adesão voluntária" dos indivíduos, sobretudo quando a relacionamos às idades do curso da vida, pois:

na vida familiar, pais, de certo modo, negociam com seus filhos, por exemplo, as atividades extra-escolares, uma vez que, em geral, não se considera como suficiente apenas a educação escolar, esta sim obrigatória. Apesar do desejo dos pais de propor novas modalidades de educação aprendizado de línguas, artes, esportes, entre outros - há sempre um espaço para a adesão do próprio sujeito, pois, sem um mínimo de concordância e aceitação, a proposta não se efetiva. (SPOSITO, 2008, p. 88, grifo nosso).

Ainda, segundo a socióloga brasileira, tendo em vista as características atuais da "vida social", a educação não formal pode ser também representada como "educação permanente", pois indivíduos jovens, adultos e velhos podem com ela se envolver. E reafirma Sposito (2008, p. 88): “mesmo sendo reconhecida como importante, [a educação não formal] sempre

\footnotetext{
${ }^{26}$ Na edição francesa: "L'éducation non formelle au contraire a lieu majoritairement em dehors Du système éducatif formel et est volontaire. Celle-ci est obligatoire pour la majorité dês élèves et doitre poser sur une motivation d'apprentissage extrinsèque. L'éducation non formelle présenteen revanche l'avantage d'être volontaire et peut em príncipe compter sur la motivation intrinsèque dês participants". (2003, p. 10; grifo nosso).
} 
pressupõe uma busca do sujeito que considera relevante construir outros caminhos para a sua formação".

Outra proposição de Sposito (2008) que adotamos ao longo do estudo desenvolvido é considerar que existe uma grande diversidade de arranjos institucionais no âmbito do que se convencionou chamar de educação não formal, portanto, ao dizermos educação não escolar, nos referimos também a "muitas das propostas são fortemente estruturadas, com bases institucionais sólidas, distantes do que poderia ser consagrado como o campo do não formal”. (SPOSITO, 2008, p. 88).

No Brasil, nas últimas décadas, foi possível constatar um incremento de ações socializadoras de atenção estatal e não estatal voltadas à dimensão educacional das iniciativas não escolares ${ }^{27}$. Dentre elas figuram programas ou políticas públicas desenvolvidos pelas esferas federal, estadual ou municipal de governo, através de ação direta ou através de parcerias com organizações não governamentais ( $O N G$ 's), além de ações realizadas a partir de fundações, de caráter privado e outras formas de organização da sociedade civil. Muitas dessas iniciativas caracterizam-se por oferecer algum tipo de atividade formativa, e, segundo Dayrell et al (2007, p.47), boa parte das iniciativas visou "desenvolver ações educativas para os jovens, voltadas ora para a formação da cidadania, ora para a profissionalização e muitas vezes se dão por meio de atividades artístico-culturais", a exemplo da proposta de educação "não escolar" de fazer teatral focalizada pela pesquisa que desenvolvemos, oferecida pelo Instituto Ribeirão em Cena - IRC.

\subsection{Contribuições da formação teatral aos processos de socialização dos jovens}

Análises sobre a atividade teatral - formativas, criação e fruição - podem ser encontradas em diversas áreas do conhecimento, e pesquisadores das Ciências Humanas e Sociais buscaram analisar o teatro por vários prismas, inclusive buscando possíveis

\footnotetext{
${ }^{27}$ Segundo Gohn (2008), “ até os anos 1980 a educação não-formal foi um campo de pouca importância no Brasil, porém a partir dos anos 1990 "a educação não-formal ganha um grande destaque, graças às mudanças na economia, sociedade e mundo do trabalho", sendo assim os processos de aprendizagem em grupos são valorizados e os valores culturais que articulam as ações dos indivíduos ganham grande importância.”. Por outro lado, Sposito (2008, p. 88) relembra que no país, “a educação não-formal já consolidou uma tradição que se iniciou no início da década de 1960 com os movimentos de educação ou de cultura popular. Naquele momento, os elementos ético-políticos das práticas eram mais fortes e visíveis, traduzidos muitas vezes na idéia da conscientização das massas populares. Mas, na contemporaneidade, as propostas de educação não-formal, influenciadas em parte pelo debate europeu, incluem o reconhecimento das necessidades contínuas de educação, que vão além da escola, derivadas das grandes transformações do capitalismo nos últimos decênios. Neste âmbito são introduzidos os temas da informação e do conhecimento como variáveis fundantes dos mecanismos da sociabilidade e do poder na contemporaneidade".
} 
contribuições aos processos cognitivos, estéticos, éticos, de educação formal e não formal dos indivíduos que se encontram em diferentes estações do curso da vida ciclo vital - infância, juventude, adultez e velhice.

Alguns autores, como Richard Courtney (1980), têm interesse pelo teatro enquanto atividade coletiva realizada pelo homem, dando destaque às interações sociais e culturais que o fazer teatral possibilita.

Courtney (1980) realizou pesquisa na qual documentou o pensamento de autores da psicologia, da antropologia social, da psicanálise, dando destaque às implicações cognitivas inerentes ao fazer teatral. Suas contribuições podem nos auxiliar a entender como o teatro pode contribuir para a socialização dos jovens, pois, segundo ele o teatro traz em si aquilo que diferencia o homem dos demais animais, na medida em que ele atua sobre a "imaginação criativa" do ser humano, e de acordo com o autor é esta capacidade, "essencialmente dramática" por natureza, que capacita o homem a "dominar seu meio de modo tal que ele supera as limitações de seu cérebro, de seu corpo e de seu universo material" (COURTNEY, 1980, p. 3). Tal afirmação encontra fundamentação na psicologia de L. S. Vygostky (1984), quando afirma que a imaginação representa uma "forma especificamente humana de atividade consciente que não está presente nas crianças muito pequenas e está ausente nos animais. Ela surge na forma do jogo, que é o pensamento em ação" (VYGOSTKY, 1984, p. 62, grifo nosso.)

A respeito das contribuições que o teatro oferece aos processos educativos do indivíduo, tanto do ponto de vista formativo como da perspectiva da fruição, Joana Lopes (1989) apresenta posição semelhante à de Courtney (1980), pois para a autora o potencial educador e transformador do teatro reside em sua capacidade de despertar a criatividade e a imaginação dos indivíduos. Para esta autora, o teatro comporta "significados educacionais, dirigidos para uma prática transformadora, não deve se distanciar da verdade que é ser o teatro um produto da nossa imaginação poética. Ele é jogo dramático que abre uma perspectiva de educação para quem faz e o assiste (LOPES ,1989 p 23). Sua utilidade estendese para além da análise e compreensão do mundo, pois:

por ele[o teatro]flagramos a realidade e podemos chegar a compreender que ele é um universo tão versátil quanto nós, atuantes de uma história que se desenvolve lentamente em todos os níveis de demonstração da vida humana. Nele vemos o universo reinventado com uma nova carga de emoção. Comediantes e espectadores recriam as relações humanas reinventado a si mesmo. (LOPES, 1989, p. 138). 
A capacidade da imaginação criativa que é fortalecida pelo fazer teatral e suas contribuições à compreensão e à elaboração da realidade são também reafirmadas por Augusto Boal (2002). Para este dramaturgo e pesquisador o teatro é a primeira invenção humana, "é aquela que possibilita e promove todas as outras invenções e todas as outras descobertas (BOAL, 2002, p. 27). Ainda para este autor, o fazer teatral seria também ferramenta vital para o autoconhecimento, e reflexividade, pois para ele o "teatro nasce quando o ser humano descobre que pode observar-se a si mesmo: ver se em ação, ou seja, o ser humano "descobre que pode ver-se no ato de ver-se em situação" (BOAL, 2002, p 27). Deste modo, para Boal, pela mediação da atividade teatral, o homem experimenta uma espécie de triangulação, a partir da qual:

ao ver-se percebe o que é, descobre o que não é, imagina o que pode vir a ser. Percebe onde está, descobre onde não está e imagina onde pode ir. Criase uma tríade: EU observador, EU em situação, e o Não-EU, isto é, o OUTRO. [...] Essa é a essência do teatro: o ser humano se auto-observa. (BOAL, 2002, p. 27).

Em Boal (2002), ainda, o teatro ou a teatralidade é conhecimento, autoconhecimento e subjetivação, pois trata-se da:

capacidade ou propriedade humana que permite que o sujeito se observe a si mesmo, em ação, em atividade. $\mathbf{O}$ autoconhecimento adquirido permitelhe ser sujeito (aquele que observa) de outro sujeito (aquele que age); permite-lhe imaginar variantes do seu agir, estudar alternativas. $O$ ser humano pode ver-se no ato de ver, de agir, de sentir, de pensar. Ele pode sentir-se sentindo, e se pensar pensando. (BOAL, 2002, p. 27, grifo nosso).

Assim, para aquele autor, o teatro é caminho para a reflexividade e para a compreensão de quem somos, é um ato intencional de busca da identidade. Auto conhecer-se é diferenciar-se do outro. Para tanto é necessário reconhecer o outro. E é necessário, tornar-se ator, reconhecer se como tal e agir. Isso nos leva as palavras de Paulo Freire (1981) sobre o vir a ser homem. A subjetivação, a autonomia é uma conquista que emerge a partir da ação do sujeito:

no processo de "hominização" em que a reflexão se instaura, se verifica o "salto individual, instantâneo, do instinto ao pensamento". Desde aquele remotíssimo momento, porém, a consciência reflexiva caracterizou o homem como um animal não apenas capaz de conhecer, mas também capaz de saber-se conhecendo. Desta forma, ao emergir, a consciência emerge como "intencionalidade" e não como recipiente a ser enchido. A percepção crítica deste fato, de um lado, desfaz o dualismo simplista que estabelece uma inexistente dicotomia entre a consciência e o mundo; de outro, retifica o 
equívoco em que se encontra a consciência ingênua, ideologizada nas estruturas da dominação, tal o de considerar-se como aquele recipiente vazio a ser enchido de conteúdos. (FREIRE, 1981, p.84).

Augusto Boal e Viola Spolin, afirmam que o teatro pode fazer parte da vida de qualquer pessoa. Spolin diz que toda pessoa é capaz de atuar e para isso deve exercer sua liberdade através do jogo, como forma de autoconhecimento e afirmação da identidade pessoal (SPOLIN, 1982, p. 7). Para ela o fazer teatral seria um espaço de autoconhecimento, e de aguçar a percepção do mundo que nos cerca e de exercício da liberdade e da sensibilização, pois “antes de jogar, devemos estar livres. É necessário ser parte do mundo que nos circunda e torná-lo real tocando, vendo, sentindo o seu sabor, e o seu aroma - o que procuramos é o contato direto com o ambiente" (SPOLIN, 1982, p.7). O mundo deve ser "investigado, questionado, aceito ou rejeitado. A liberdade pessoal para fazer isso leva-nos a experimentar e adquirir autoconsciência (auto-identidade) e auto-expressão" (SPOLIN, 1982, p. 7).

\subsubsection{O teatro, o fazer teatral e a importância do jogo para a educação do indivíduo}

Além dos temas da "imaginação criativa", do autoconhecimento, auto-identidade da reflexividade, o jogo, espaço-tempo de interações sociais, sociabilidades, aprendizagens, educação e regras, é uma categoria que também se faz presente em estudos dedicados ao teatro, tanto naqueles trabalhos que se voltam à tematização do fazer teatral seja naqueles que dedicam o aspecto da fruição do teatro (SLADE, 1978; COURTNEY, 1980; BERGER, LUCKMAN, 1994; LOPES, 1989; HUIZINGA, 1980;). Em diferentes autores, o jogo aparece em diversas formas ou nomenclaturas: jogo dramático, jogo de improvisação, jogo pessoal, jogo projetado, entre outros.

Peter Slade (1978), que pesquisou durante grande parte de sua vida o jogo realizado por crianças e jovens em escolas ou fora delas, afirma que o jogo dramático é uma parte vital da experiência do jovem e também "uma maneira de pensar, comprovar, relaxar, trabalhar, ousar, experimentar, criar e absorver" (SLADE, 1970, p. 13). Para Lopes o jogo dramático, base do teatro, é uma linguagem de corpo e voz que articulamos na infância, mas que posteriormente esquecemos, matamos, ou que usamos timidamente quando é preciso contar um fato que o discurso oral, branco e a frio, não comunica inteiramente. (LOPES, 1970, p. $113)$.

Encontramos em autores como Lopes (1970), Courtney (1980), Huizinga (1980) Spolin (1982) e Boal (2002) a ideia de que as primeiras experiências de jogo estariam 
localizadas na infância, porém o jogo acompanharia o indivíduo até a fase adulta, diferenciando-se com o passar dos anos. Segundo Courtney (1980, p. 21, grifo nosso):

a criança em desenvolvimento tem um primeiro ano de vida que é essencialmente motor; e então- com algumas crianças isso ocorre de maneira súbita- ocorre a mudança: passa a jogar, desenvolve seu humor, finge ser ela mesma ou outro alguém. A criança passou por outras mudanças anteriormente, algumas extremamente importantes, mas este é o desenvolvimento especifico que difere o homem de outras criaturas vivas- a habilidade para compreender o ponto de vista de outrem, perceber em uma situação suas possibilidades cômicas, perceber as qualidades inerentes a duas diferentes ideias e a possível ação entre elas. [...] Fingir ser outra pessoa- atuar- é parte do processo de viver; podemos "fazer de conta", fisicamente quando somos pequenos, ou fazê-lo internamente quando somos adultos. Atuamos todos os dias: com nossos amigos, com nossa família, com estranhos. A imagem mais comum nesse processo é a máscara e a face: nosso verdadeiro eu está escondido por muitas máscaras que assumimos durante o decorrer de cada dia. Atuar é o método pelo qual vivemos com o nosso meio, encontrando adequação através do jogo.

O jogo é analisado também de forma aprofundada e abrangente pelo historiador holandês Johan Huizinga (1980), o qual dedica parte de sua pesquisa a buscar as características do jogo através dos tempos. Em sua acepção o jogo "é uma atividade que se processa dentro de certos limites temporais e espaciais, seguindo uma determinada ordem e um dado número de regras livremente aceitas e fora da necessidade ou da utilidade material" (HUIZINGA 1980, p. 147). Sua obra "Homo Ludens" é uma investigação sobre a importância do jogo e o caráter lúdico na construção nas relações sociais. Johan afirma a importância das investigações sobre o jogo realizadas por diferentes áreas do saber, além de sua importância para o desenvolvimento humano, segundo ele o jogo é fundamental na fase juvenil da vida na medida em que contribui aos processos de experimentação e preparação dos adolescentes e jovens. Segundo o autor:

a psicologia e a fisiologia procuram observar, descrever e explicar o jogo dos animais, crianças e adultos. Procuram determinar a natureza e o significado do jogo atribuindo-lhe um lugar no sistema da vida. A extrema importância desse lugar e a necessidade, pelo menos a utilidade da função do jogo, são consideradas coisa assente, constituído ponto de partida de todas as investigações científicas desse gênero [...]. Segundo uma teoria, o jogo constitui uma preparação do jovem para as tarefas sérias que mais tarde a vida exigirá, segundo outra, trata-se de um exercício de autocontrole indispensável ao indivíduo. [...] todas elas partem do pressuposto de que o jogo se acha ligado a alguma coisa que não seja o próprio jogo. (HUIZINGA, 1980, p.6).

Como visto, as atividades lúdicas acompanham o homem através da socialização primária e secundária. Para os sociólogos Berger e Luckmman (1994) o teatro é um exemplo 
de atividade lúdica realizada por adultos. Os autores se referem aqui o efeito da fruição teatral, não do fazer propriamente dito, porém reforçam a presença do "jogo" naquilo que chamam de "campos finitos de significação e enclaves, dentro da realidade, marcados por significados e modos de experiência delimitados" (BERGER; LUCKMANN, 1994, p. 46). Para os autores, a ida ao teatro proporciona uma suspensão momentânea da realidade, depois da qual a "consciência sempre retorna a realidade como "se voltasse de uma excursão (BERGER; LUCKMANN, 1994, p. 46). Portanto, os autores concordam que o jogo acompanha a socialização nas diferentes etapas ou fases do ciclo vital dos indivíduos, desde a infância até à velhice, pois:

o teatro oferece uma excelente ilustração desta atividade lúdica por parte dos adultos. A transição entre as realidades é marcada pelo levantamento e pela descida do pano. Quando o pano se levanta, o espectador é "transportado para outro mundo" com seus próprios significados e uma ordem que pode ter relação ou não com a ordem da vida cotidiana. Quando o pano desce, o espectador; "retorna a realidade", isto é, à realidade predominante da vida cotidiana, em comparação com a qual a realidade do palco parece agora tênue e efêmera, por mais vívida que tenha sido a representação alguns poucos momentos antes. A experiência estética e religiosa é rica em produzir transições dessa espécie, na medida em que arte e religião são produtores endêmicos de campos de significação. (BERGE; LUCKMANN, 1994, p. $43)$.

As contribuições do fazer teatral vivenciado pelos jovens dar-se-iam, portanto, no âmbito do reconhecimento do mundo e de si mesmo, tendo o jogo como uma das muitas mediações que contribuem para a concretização do fazer teatral.

Pelo apresentado até aqui, meu estudo tomou como hipótese o fato de que a participação dos jovens em oficinas de teatro pode contribuir para seus processos socializadores, cognitivos, estéticos, éticos, suas interações sociais, aos seus processos identitários, seus processos de subjetivação ou autonomia, pois elas podem propiciar um espaço/tempo de trocas simbólicas, de construção coletiva de signos, protagonizado por diferentes subjetividades que encontram no jogo o objetivo de construírem algo juntos, processo que envolve escolhas, análises de situações e negociações entre os indivíduos, como vemos nas palavras de Flávio Desgranges (2011, p. 72, grifo nosso):

pode se caracterizar o jogo dramático como uma atividade grupal. Em que o indivíduo elabora por si e com outros as criações cênicas, valendo se das apresentações no interior das oficinas como um meio de investigação e apreensão da linguagem teatral. Desenvolvem-se, no decorrer do processo, as possibilidades expressivas e analíticas, exercitando o participante tanto para dizer algo através do teatro, quanto para uma interpretação aguda dos diversos signos visuais e sonoros que constituem uma encenação teatral [...] 
apresenta-se também como um instrumento de análise do mundo: as situações cotidianas são vistas e revistas, moldadas e modificadas no jogo, e o indivíduo pode sempre parar e voltar atrás e tentar de novo.

\subsubsection{Contribuições cognitivas - linguagem e pensamento.}

Segundo Courtney as artes são citadas no domínio psicanálise como um exemplo de equilíbrio entre o consciente e o inconsciente. $\mathrm{O}$ autor afirma que na psicologia desenvolvida por Sigmund Freud às referências as terminologias do teatro e das artes são frequentes (COURTNEY, 2003, p. 109). Segundo Freud:

Na medida em que a pressão dos instintos aparece e uma solução neurótica parece iminente, a defesa inconsciente contra isso conduz a criação de um produto de arte. [...] Portanto, a pessoa criativa permite um intercâmbio entre o consciente e o ego. Freud ainda atribui o fundamento dessa capacidade à infância: Não se esqueça de que o realce dado às memórias infantis do escritor, o que talvez pareça estranho, deriva se em última análise, da hipótese de que a imaginação criativa, como o devaneio, é uma continuação e um substituto para o jogo da infância. (FREUD apud COURTNEY, 1980, p. 11; grifo nosso).

Outro estudioso da psicanálise que refletiu sobre o assunto abordado é J. A. Hadfield, segundo o qual a função dos sonhos e do jogo é "reproduzir experiências não solucionadas da vida e encontrar soluções" (HADFIELD apud COURTNEY, 1980, p. 16). Os sonhos e o jogo tomam o lugar da experiência; ao reviver as experiências na imaginação é possível examinar os problemas da vida pelo processo ensaio-e-erro e prevenir as consequências (HADFIELD apud COURTNEY, 1980, p.74). Segundo o autor a repetição no jogo e nos sonhos “impulsiona os problemas não solucionados até que sejam resolvidos, e serve ao mesmo propósito que os processos de ideação: a formação de imagens mentais (HADFIELD apud COURTNEY, 1980, p. 75).

Mais uma contribuição, ainda no campo da psicanálise é de Daniel Schneider. Para ele o artista traduz os sonhos em formas que são inteligíveis e esteticamente agradáveis para a consciência universal do homem (SCHNEIDER apud COURTNEY, 1980, p. 111). Segundo ele:

A forma de arte é essencialmente a forma de um sonho... um sonho cuja forma é a do sonho de uma pessoa adormecida e composto exatamente pelas mesmas forças, sendo então, virados às avessas, orientando-se para a realidade do mundo externo mais do que para a realidade do mundo dos sonhos [...]. A técnica artística é um controle do poder inerente do 
inconsciente em seu processo de elaboração do sonho. (SCHNEIDER apud COURTNEY, 1980, p. 111).

A partir da preocupação dos autores supracitados em relacionar a arte a processos cognitivos conscientes e inconscientes, podemos inferir ao teatro importância enquanto assunto a ser investigado por especialistas das áreas da psicologia e psicanálise, que apesar de não serem assuntos abordados pelo presente estudo, são essenciais para a compreensão do ser humano.

\subsubsection{A questão do corpo: autoconhecimento e exploração das potencialidades.}

No campo de pesquisa que envolve o fazer teatral é constante a preocupação com os cuidados relativos ao corpo, ao desenvolvimento da motricidade, mormente chamados de expressão corporal ou conscientização corporal, noções que compreendem tanto o autoconhecimento, funcionamento de seu corpo até a exploração de seus limites e potencialidades.

No dia a dia o corpo é suscetível a mecanizações que turvam os sentidos e a própriocepção : nas palavras de BOAL (1980, p. 89), "na batalha do corpo contra o mundo, os sentidos sofrem, e começamos a sentir muito pouco daquilo que tocamos, a escutar muito pouco daquilo que ouvimos, a ver muito pouco daquilo que olhamos”. Para Sônia Machado Azevedo (1990, p. 138) “o ator é seu próprio corpo, e seu corpo não pode jamais ser tratado como uma entidade apartada de si, suprimida e castrada em suas emoções e pensamentos". Para a autora, é necessária a busca de uma resposta de corpo inteiro, sem preconceitos, para que "a máscara usual e cotidiana seja rompida, já que na no social a ordem é a da ocultação e do disfarce na manutenção das aparências convenientes”. (AZEVEDO, 1990, p. 138).

Uma significativa parte das práticas educativas inerentes aos processos de conscientização corporal são os chamados exercícios de sensibilização, comuns a várias linhas de ensino teatral. Sua utilidade reside em ativar a percepção, aguçando ou despertando a atenção sobre as possibilidades que os sentidos, muitas vezes adormecidos pela rotina, podem nos oferecer em relação ao mundo. Repousam sobre o ritmo da respiração, o tato, a percepção temporal, são processos subjetivos e muitas vezes difíceis de se verbalizar em em imediato , mas passíveis de uma racionalização posterior. Como afirma Azevedo (2004, p. 136):

raciocinar sobre as coisas difere do ato de percebê-las. Pensar sobre alguma coisa exige, na maioria dos casos, que um eu se afaste e de uma certa 
distância contemple seu objeto de estudo, para poder tecer considerações objetivas sobre ele. Perceber, ao contrário, é uma fusão instantânea, imediata, do sentir e uma constatação desse mesmo sentir; não há separação e sim união: dados de realidade, colhidos pelo eu senciente, sem mediação do raciocínio, são recebidos pelo indivíduo; nesse sentido a percepção é uma forma de conhecimento não racional.

A importância dos exercícios de expressão e conscientização corporal encontram respaldo nas afirmações de Fabbrinni e Melucci (1992) quando os autores afirmam que na fase juvenil, compreender o que acontece com o corpo não se refere nunca aos fatores físicos como tais, mas aos sentidos que estes têm para a pessoa que os experimenta e a sua permanente relação com a construção de significados, sobre a realidade social, individual e sobre as relações entre o indivíduo e a natureza.

A partir dos aportes conceituais apresentados nas páginas anteriores, o trabalho de campo teve por objetivo central produzir conhecimento sobre as contribuições que uma proposta não escolar no campo do fazer teatral oferece aos processos de "socialização secundária", independência e autonomia de jovens ribeirão-pretanos ou não, com idades entre 17e 29 anos, desenvolvida por organização não governamental inserida na espacialidade urbana e sociocultural de Ribeirão Preto, o Instituto Ribeirão em Cena, que será apresentada a seguir. 


\title{
3 O INSTITUTO RIBEIRÃO EM CENA, SUA PROPOSTA DE EDUCAÇÃO NÃO ESCOLAR EM TEATRO E OS JOVENS PARTICIPANTES DA PESQUISA
}

\begin{abstract}
Penso que devemos defender a ideia de que, assim como todas as outras práticas sociais de vocação humanista, a ciência e a educação que desejamos praticar e através das quais aspiramos descobrir e ampliar ad infinitum sujeitos e campos sociais de diálogo criador e emancipatório devem partir desde o lugar social da comunidade humana concreta e cotidiana e devem desaguar no território de vidas humanas e histórias reais.
\end{abstract}

Carlos Rodrigues Brandão ${ }^{28}$

Nesta seção, me propus a um duplo propósito: o primeiro é o de apresentar a iniciativa de educação não escolar do fazer teatral acessada por jovens que colaboraram com a pesquisa (ribeirão-pretanos ou não); o outro será o de apresentar breves retratos dos jovens que comigo dialogaram sobre as interações sociais e as experiências que os conduziram àquela proposta socializadora e educação não formal na área da cultura artística teatral.

Em relação ao primeiro propósito convêm ressaltar que, no âmbito da investigação desenvolvida o Instituto Ribeirão em Cena - IRC e seu curso de iniciação teatral foram tomados como "categorias analíticas" e não como "unidades empíricas" de estudo (SPOSITO, 2008). Entretanto, julguei importante apresentar ao leitor aquele Instituto, dando destaque aos objetivos que ele se propõe a atingir (sua “missão"), como espaço-tempo de socialização e educação não escolar de jovens e adultos, bem como a sua iniciativa de educativa em teatro, repertório de componentes formativos e suas intencionalidades.

Quanto ao conteúdo dos retratos de cada um dos sujeitos do estudo, explorou-se as narrativas que formularam nas entrevistas e delas extraiu-se as seguintes referências:

1) Dados sociodemográficos (idade, pertencimento étnico-racial, local de moradia, nível de escolaridade atingido à época das entrevistas, se inseridos ou não esfera do trabalho); e

2) Dados socioculturais da família de origem, nível máximo de escolaridade atingida e situação ocupacional de seus respectivos pais e mães ou responsáveis.

Para a montagem dos retratos usou-se também informações que os jovens forneceram acerca dos percursos que percorreram até a escolha e definição que fizeram pelo curso de fazer teatral do Instituto. A hipótese que nos guiou neste caso foi de que a aposta que fizeram pela iniciativa socializadora e de educação não escolar do IRC pode ser compreendida como uma expressão de como eles enfrentam o desafio - com tensões, conflitos, e negociações - de

\footnotetext{
${ }^{28}$ Perguntas, pesquisas. Para Quem?Para quê? Processos educativos em práticas sociais: pesquisas em educação, 2014, p. 13
} 
construírem seus processos de identização (MELUCCI, 2004), de autonomia, nas circunstâncias históricas em que vivem a juventude (SINGLY, 2005; MARTUCCELLI, 2007; 2012).

\subsection{O Instituto Ribeirão em Cena - IRC: elementos sobre origens da organização}

O Instituto Ribeirão em Cena - Escola de Teatro é uma organização cultural, sem fins lucrativos, que busca "promover o ensino e a difusão do Teatro com vista à inclusão sociocultural e educacional" ${ }^{29}$. A organização civil foi fundada em 2001, e vem se firmando como verdadeiro centro educativo onde se cruzam áreas e componentes diversos da experiência teatral - nos campos da formação, difusão, fruição.

Segundo o fundador do $\operatorname{IRC}^{30}$ a história da organização tem como referência evento ocorrido em núcleo de favela situado no bairro Jardim Jandaia, zona norte da cidade. Em entrevista concedida em $2011^{31}$ aquele agente esclareceu que uma das razões que o induziu a criar o Instituto ata-se a experiências de jovens ribeirão-pretanos, que figuraram ao mesmo tempo como vítimas e algozes de episódios de violência urbana: "em 2001, Ribeirão Preto vivia uma guerra de gangues e [...] 80\% dos homicídios eram de jovens entre 16 e 25 anos. [Brigagão] trabalhava em uma reportagem e ao entrevistar um menor que havia cometido um assassinato, o jovem teria pedido a ele que o mostrasse no jornal” (DICAS MULHER, 2011).

O Jornalista, sentindo-se consternado com o pedido do jovem, pôs em xeque a função social de sua profissão - o jornalismo, na medida em que ele o colocou diante de uma demanda por "promoção" ou "espetacularização" de um ato de violência envolvendo atores juvenis, pedidos que contrastavam com seus "princípios morais e éticos". Após esse evento, Brigagão deixou a emissora de TV em que trabalhava e deu início a um projeto de formação de atores na favela: "nós resolvemos fazer um trabalho de dar oportunidade aos jovens que não fosse o crime" (DICAS MULHER, 2011).

Não muito tempo depois, o projeto teve que se deslocar do bairro em virtude de ameaças formuladas por indivíduos ligados ao mundo do ilegal e do ilícito que ali controlavam atividades relacionadas ao tráfico de drogas (DICAS MULHER, 2011).

\footnotetext{
${ }^{29}$ RIBEIRÃO EM CENA. Inicial. Disponível em: $<$ http://www.ribeiraoemcena.org.br/index.php>. Acesso em: 20 jun. 2015.

${ }^{30}$ Antonio Gilson Brigagão, jornalista, formado em dramaturgia e ator.

${ }^{31}$ DICAS MULHER. Conheça o Ribeirão em Cena. 2011. Disponível em

$<$ http://dicasmulher.com.br/artigo/conheca-o-ribeirao-em-cena/>. Acesso em: 20 jun. 2015.
} 
Desta maneira, o espaço físico do IRC foi transferido para o território situado em região central da cidade, onde hoje vem realizando a atividades socioculturais e de educativas.

\subsubsection{A “missão" do IRC: inclusão e formação profissional por intermédio do curso de iniciação teatral}

De acordo com o sítio eletrônico do IRC, a missão mais ampla do Instituto é a de "incluir pessoas à formação de qualidade e difundir cultura, ampliando as oportunidades de desenvolvimento e reforçando o conceito da arte como um instrumento de transformação humana e coletiva"; já sua "missão" específica consiste em formar "atores e atrizes, por meio do Curso de Iniciação Teatral", oferecido anualmente e de forma gratuita a jovens e adultos. O coletivo institucionalizado busca, então,

revelar talentos, formar atores, atrizes e, acima de tudo, desenvolver um trabalho de inclusão social, proporcionando a jovens e adultos o estudo de artes cênicas gratuitamente, através do ensino de disciplinas essenciais e de noções básicas de filosofia, psicologia e sociologia. O curso visa ainda retirar jovens e adultos da ociosidade intelectual, das ruas, da violência, promover a cidadania, o senso crítico e despertar a criatividade para a paz. (RIBEIRÃO EM CENA).

Além das atividades do Curso de Iniciação, o IRC compromete-se também com desenvolvimento da seguinte tríade:

1) Profissionalizar atores;

2) Incentivar e configurar novos coletivos teatrais; e

3) Produzir espetáculos, com ênfase no "teatro popular, comunitário, coletivista e centrado no ator" (RIBEIRÃO EM CENA).

\subsubsection{Organização temporal e proposta curricular do curso de iniciação teatral do IRC: educação não formal em forma escolar}

À época dos trabalhos de campo desta pesquisa, o Curso de Iniciação do Ribeirão em Cena era oferecido em três períodos diferentes do dia - manhã, tarde e noite, de segunda à quinta-feira. Na medida em que o Instituto não impunha limites etários ao acesso e a fruição de seu curso, seus responsáveis realizavam processos seletivos anuais, de forma que cada "turma" contasse com 30 indivíduos por período, no máximo. 
Os candidatos ao curso de teatro se inscrevem para um processo de seleção aos seus processos educativos. O processo de avaliação solicita aos candidatos o preenchimento de questionário com perguntas que possam caracterizá-los do ponto de vista sociodemográfico e socioeconômico, e que enfrentem dinâmicas próprias ao fazer teatral, diante de banca composta por avaliadores internos ou externos convidados - atores, psicólogos etc.

O curso de Iniciação teatral tem duração de dois (2) anos e seu "quadro curricular" é estruturado por oito (8) componentes formativos - "disciplinas", visando a cumprir um itinerário que vai desde o estudo de aspectos históricos e culturais do teatro, passam por vivências rigorosas de técnicas e movimentos corporais, também pelo ensino da dança contemporânea e técnicas vocais, de canto e musicalização, e abrange, ainda, exercícios de improvisação e a atuação. Para uma melhor descrição da proposta, a detalhamos no Quadro 1.

Quadro 1 - Componentes curriculares do Curso de Iniciação Teatral Instituto Ribeirão em Cena

\begin{tabular}{|l|l|}
\hline Componente Curricular & \multicolumn{1}{|c|}{ Conteúdos socializadores e educativos } \\
\hline Técnica Corporal & $\begin{array}{l}\text { Oferecer a prática da consciência corporal e suas possibilidades } \\
\text { expressivas; promover o autoconhecimento bio-psico-social; } \\
\text { orientar o desenvolvimento do potencial expressivo; estudar os } \\
\text { gestos humanos e seus significados; estudar a comunicação } \\
\text { infraverbal através do corpo; promover a prática da pesquisa } \\
\text { dos gestos corporais e sua aplicabilidade em cena; introduzir a } \\
\text { mímica e pantomima como uma das ferramentas para a } \\
\text { comunicação gestual; introduzir a técnica de contato- } \\
\text { improvisação como meio de comunicação entre atores; } \\
\text { incentivar a prática da criação cênica enquanto ator performer; } \\
\text { desenvolver a análise da expressividade corporal de } \\
\text { personagens; intercambiar conhecimentos teóricos e práticos } \\
\text { entre as demais disciplinas. }\end{array}$ \\
\hline 2. Improvisação & $\begin{array}{l}\text { Desenvolver a improvisação teatral como expressão do } \\
\text { movimento para a cena; analisar os procedimentos técnicos } \\
\text { para o jogo; praticar a improvisação teatral com base no } \\
\text { silêncio e na utilização de objetos; buscar elementos técnicos } \\
\text { para o uso da palavra na cena. }\end{array}$ \\
\hline 3. Atuação & $\begin{array}{l}\text { Trabalhar todos os aspectos da construção, partindo do estudo } \\
\text { de cenas retiradas de um ou vários textos, a sua } \\
\text { contextualização, a análise estrutural do texto, a determinação } \\
\text { da ação principal, a determinação dos objetivos, os conflitos, as } \\
\text { ações internas e externas, a comunicação, o texto físico e } \\
\text { emocional, o personagem e sua tridimensionalidade, a sua } \\
\text { dualidade e o seu ritmo; trabalhar a conscientização da } \\
\text { presença cênica, sua expansão e comunicação através do jogo }\end{array}$ \\
\hline
\end{tabular}




\begin{tabular}{|c|c|}
\hline & $\begin{array}{l}\text { teatral, da palavra e da respiração, além das codificações de } \\
\text { imagens e sensações corpóreas no espaço que recriem uma } \\
\text { organicidade cênica; o aluno deve aprender a dialogar através } \\
\text { do corpo e suas expressões, apropriando-se da palavra, por } \\
\text { meio do estudo minucioso de um texto e na construção de sua } \\
\text { representatividade; proporcionar uma compreensão prática e } \\
\text { teórica sobre os fundamentos da arte do teatro, especialmente } \\
\text { quanto ao papel da ação no trabalho do ator. }\end{array}$ \\
\hline 4. Canto / Técnica Vocal & $\begin{array}{l}\text { Estudar princípios básicos de fisiologia, direcionada; promover } \\
\text { o trabalho em grupo; conscientizar sobre a importância da } \\
\text { saúde vocal; desenvolver a percepção corporal e auditiva; } \\
\text { Pesquisar as possibilidades sonoras do instrumento vocal; } \\
\text { desenvolver a expressividade e sensibilidade musical; inserir a } \\
\text { compreensão da diversidade musical; estimular o processo } \\
\text { interdisciplinar; incentivar a experimentação vocal; desenvolver } \\
\text { o processo técnico vocal; contribuir para a formação artística e } \\
\text { ao trabalho do ator. }\end{array}$ \\
\hline 5. Musicalização & $\begin{array}{l}\text { Estudo de aspectos melódicos, rítmicos, formais, tímbricos, } \\
\text { instrumentais, entre outros, que possam ser extraídos de } \\
\text { músicas que ilustram o estabelecimento da tonalidade, } \\
\text { processos que conduzem a expansão do som e procedimentos } \\
\text { composicionais básicos e princípios musicais como ritmos e } \\
\text { expressões. }\end{array}$ \\
\hline 6.Dança Contemporânea & $\begin{array}{l}\text { Aplicar técnicas básicas da dança contemporânea; desenvolver } \\
\text { criatividade e percepção rítmica; ampliar repertório de } \\
\text { movimento; montagem coreográfica; reconhecer a dança como } \\
\text { meio de expressar as relações sociais. }\end{array}$ \\
\hline 7.Cenografia Teatral & $\begin{array}{l}\text { Oferecer ao aluno uma base crítico-reflexiva sobre a função do } \\
\text { cenógrafo, estimulando possibilidades de contribuição para a } \\
\text { execução de espetáculos cênicos; entender a atmosfera criada a } \\
\text { partir do perfeito relacionamento entre ator/cenógrafo/diretor. }\end{array}$ \\
\hline 8. História do Teatro & $\begin{array}{l}\text { Introduzir os alunos à reflexão teórica e estética sobre o teatro } \\
\text { em geral, a partir de uma introdução expositiva da história } \\
\text { teatral da Grécia clássica ao teatro das vanguardas históricas, } \\
\text { utilizando como exemplo alguns autores e obras chaves para a } \\
\text { configuração de um pensamento crítico sobre o teatro, } \\
\text { analisando a tradição cênica e o intenso confronto que se dá } \\
\text { entre texto e representação }\end{array}$ \\
\hline
\end{tabular}

Fonte: website RIBEIRÃO EM CENA. 


\subsubsection{Instalações e estrutura física do Instituto}

O espaço físico do IRC compõe-se de auditório com capacidade para 200 pessoas, cadeiras plásticas avulsas com um palco com piso de madeira, sem coxias, com alguns aparatos cênicos - iluminação teatral básica e $P$. A de som, onde as atividades do curso de Iniciação são realizadas. Há ainda um pequeno foyer com um sofá e quadro de avisos, dois banheiros para o público, um dois quais só é acessível ao subir uma escada; no lugar, duas salas são direcionadas as atividades administrativas e nelas também ocorrem as reuniões dos educadores $^{32}$.

Pelo apresentado nos parágrafos anteriores e também no Quadro 1, pode-se perceber que os seus fundadores e mantenedores compreendem o Instituto como "uma escola", e seu curso de Iniciação adota, claramente, a "forma escolar" de socialização e educação, contudo, o Curso não possui, em realidade, o estatuto legal de um curso de educação profissional ou técnica, tendo em vista o disposto no Capítulo III, da Lei de Diretrizes e Bases da Educação Lei Federal 9.394/1996 ${ }^{33}$, que define aquela modalidade de educação da seguinte forma:

Art. 39A educação profissional e tecnológica, no cumprimento dos objetivos da educação nacional, integra-se aos diferentes níveis e modalidades de educação e às dimensões do trabalho, da ciência e da tecnologia.

$\S 10$ Os cursos de educação profissional e tecnológica poderão ser organizados por eixos tecnológicos, possibilitando a construção de diferentes itinerários formativos, observadas as normas do respectivo sistema e nível de ensino.

$\S 20$ A educação profissional e tecnológica abrangerá os seguintes cursos:

I - de formação inicial e continuada ou qualificação profissional;

II - de educação profissional técnica de nível médio;

III - de educação profissional tecnológica de graduação e pósgraduação.

§ 3o Os cursos de educação profissional tecnológica de graduação e pósgraduação organizar-se-ão, no que concerne a objetivos, características e duração, de acordo com as diretrizes curriculares nacionais estabelecidas pelo Conselho Nacional de Educação.

Art. 40 A educação profissional será desenvolvida em articulação com o ensino regular ou por diferentes estratégias de educação continuada, em instituições especializadas ou no ambiente de trabalho.

Art. $41 \mathrm{O}$ conhecimento adquirido na educação profissional e tecnológica, inclusive no trabalho, poderá ser objeto de avaliação, reconhecimento e certificação para prosseguimento ou conclusão de estudos. (BRASIL, 1996, grifo nosso).

\footnotetext{
${ }^{32}$ Mesmo espaçoso, o prédio do Instituto encontra-se com suas dependências com problemas estruturais, pois há paredes soltando o reboco, há placas do forro descoladas, e outros problemas estruturais, como por exemplo, a ausência de saídas de emergência adequadas, exigida pelo corpo de bombeiros.

${ }^{33}$ Texto atualizado da Lei Federal 9.394 de 1996.
} 
Embora os responsáveis pelo Instituto a tenham se inspirado no "modelo escolar" ou a “forma escolar" (VICENT; LAHIRE; THIN, 2001; REYMOND, 2003; GOHN, 2006; 2008) para a organização temporal, a formulação da proposta curricular e as práticas socializadoras e educativo-culturais de seu curso de Iniciação Teatral, ele é, contudo, uma proposta educação não formal (GOHN, 2006; 2008; REYMOND, 2003) ou educação não escolar (SPOSITO, 2008): seja do ponto de vista do espaço-tempo onde ele se desenvolve, seja pelo fato do Curso não contar com as figuras de professores e alunos - figuras fundantes e exclusivas da instituição escolar. Contudo, a proposta educativa do fazer teatral do IRC apresenta-se fortemente estruturada, apresenta alto grau de institucionalização (SPOSITO, 2008, p. 88).

\subsubsection{Sociabilidades ${ }^{34}$ construídas no cotidiano do Curso de Iniciação do IRC}

A porta de entrada do Instituto dá acesso ao foyer do teatro. É uma porta de vidro, que fica constantemente aberta durante o dia. Ao adentramos no Foyer, vemos um sofá de alvenaria, com almofadas e temos a esquerda à porta grande, deslizante, que dá acesso ao teatro. Em frente a essa porta temos o banheiro feminino e um bebedouro. Se, ao contrário nos dirigirmos à direita veremos uma escada que nos permite, ao subirmos por ela, chegar às salas administrativas, uma biblioteca que se encontra em fase de catalogação, uma sala de figurinos e adereços e o banheiro masculino. Foi possível notar que a secretaria também é frequentada pelos educandos, quando precisam encontrar algum dos educadores, o que nos pareceu ser algo realizado sem constrangimento, exceto quando havia alguma reunião pedagógica.

O foyer serve também como ponto de encontro e interações dos jovens, pois no início das entrevistas foram feitas tentativas de realizá-las naquele lugar, mas devido à grande circulação de pessoas, optamos por realizá-las em outros lugares, preferencialmente escolhidos pelos jovens que aceitaram colaborar com o estudo.

Também foi possível observar que alguns jovens que já concluíram o curso de Iniciação continuam a frequentar, ocasionalmente, o espaço do foyer. Em geral, os jovens que

\footnotetext{
${ }^{34}$ De acordo com Georg Simmel (1983), o "fenômeno da sociabilidade" pode ser compreendido como: "o estar com um outro, para um outro, contra um outro que, através do veículo dos impulsos ou dos propósitos, forma e desenvolve os conteúdos e os interesses materiais ou individuais. As formas nas quais resulta esse processo ganham vida própria. São liberados de todos os laços com os conteúdos; existem por si mesmo e pelo fascínio que difundem pela própria liberação destes laços. [...] Interesses e necessidades específicas certamente fazem com que os homens se unam em associações econômicas, em irmandades de sangue, em sociedades religiosas, em quadrilhas de bandidos. Além de seus conteúdos específicos, todas estas sociações também se caracterizam, precisamente, por um sentimento, entre seus membros, de estarem sociados, e pela satisfação derivada disso" (SIMMEL, 1983, p. 168 apud ALCÂNTARA JÚNIOR, 2005, p. 34).
} 
retornam esperam sentados nos sofás até o intervalo das atividades formativas, quando então se dirigem aos educandos ou educadores.

[...] os educandos estavam descontraídos na entrada do espaço, que é como um foyer de teatro, de frente pra rua, alguns tocavam violão e conversavam, me cumprimentaram como se fosse aluno também, me ofereceram biscoitos, conversavam, riam. Enchiam as garrafas de água para uns dos outros, alguns faziam um lanche rápido. Outros ainda em uniforme escolar chegavam correndo!

A educadora se atrasou.

Uma adolescente terminava, deitada no chão, realizava um trabalho escolar. (Caderno de campo, 20/02/2015).

Em sua maioria, as regras de convivência e os acordos entre educadores e jovens são realizados oralmente. No espaço não estão afixadas placas indicando "silêncio", ou "cuide da limpeza", nem mesmo no quadro de aviso, esse costuma conter recortes de jornal e cartazes sobre atividades culturais as mais diversas. Os jovens negociavam entre si a divisão do trabalho relativo à manutenção do espaço, como existem três turmas, há um acordo de que a turma anterior deveria deixar o espaço em ordem para o horário seguinte. Tudo era limpo a cada turma, para que a seguinte tivesse o espaço em condições. Isso incluía invariavelmente, palco e plateia, sendo essa última formada por grandes patamares em formato de escada, que servem para nivelar as diferentes alturas, permitindo maior visibilidade em relação ao palco para público que se acomoda em cadeiras plásticas removíveis.

Uma das dificuldades encontradas no processo de observação e registro reside no grau de subjetividade das atividades que envolvem a criação artística, a descrição visual do que é elaborado não nos pareceu colaborar com os intuitos da pesquisa, caso os objetivos do estudo fossem avaliar as práticas teatrais ali realizadas, a descrição das técnicas e exercícios seriam mais apropriadas. Portanto, no que diz respeito às dinâmicas empregadas pelos professores não as entraremos aqui em maiores detalhes.

Porém, podemos afirmar que as práticas mais comumente observadas seguiam certa sequência: aquecimento individual, aquecimento coletivo, troca de informações sobre o exercício anterior, exercícios de criação individual ou coletiva, demonstração de sequências cênicas criadas pelos alunos e reflexão coletiva sobre a criação.

Durante os encontros os jovens realizavam uma pausa para o café, e se dirigiam a um balcão que se encontra na extremidade oposta do palco, equipado com forno micro-ondas, cafeteira e uma geladeira. Ali preparavam rapidamente seus lanches, conversavam sobre assuntos variados e retornavam às atividades, o horário da pausa foi combinado dia a dia entre 
os educadores e os jovens, de acordo com o tempo que tinham para desempenhar as tarefas planejadas.

Muitas das práticas presenciadas foram desenvolvidas em círculo: o aquecimento coletivo, as discussões e decisões de cena, as apreciações e devolutivas do educador sobre as cenas criadas, são conduzidas com os jovens e os educadores em roda em pé, ou sentados no chão:

Os jovens e os educadores sempre tiram os sapatos ao entrarem no ambiente de trabalho. Os jovens estavam em aquecimento, em roda faziam alongamentos. Pararam um pouco para ouvir a minha apresentação pela educadora, tudo muito rápido. Então continuaram a se aquecer. A educadora deixou-os a vontade, acompanhava de fora sorrindo, enquanto eles se 'dirigiam" uns aos outros, dando ideias de que exercício viria agora na sequência, corrigindo uns aos outros em suas posturas corporais, e reclamando de dores enquanto riam: 'Ei , passa outro exercício! Quer me matar assim! Vamos pular esse!'

Tudo sério, mas descontraído ao mesmo tempo. Durante esse tempo um coordenador do espaço veio e perguntou quem era o "responsável" pela turma. "Eu" respondeu uma jovem, o coordenador solicitou a ela que pegasse o nome de quem pudesse cuidar da entrada do espaço e receber o público nesse fim de semana, ela perguntou quantas pessoas, ele responde "três". O aquecimento continua por mais cinco (5) minutos, e a educadora vai fazendo uma contagem regressiva: 'falta um (1) minuto'. (Caderno de Campo, 20/02/2015).

O período que compreendeu nossa pesquisa contou com um fator inesperado que exigiu a participação efetiva dos jovens envolvendo-os em atividades que iriam para além do fazer teatral foi - como citando anteriormente - o Instituto passou por dificuldades financeiras, então alguns dos jovens engajaram-se para angariar fundos realizando bazares, saraus e brechós, nos quais se revezavam nas tarefas, ou ainda mesmo divulgando as ações em locais públicos como praças e faróis das avenidas, tocando seus instrumentos com figurinos teatrais para difundir a campanha que foi lançada via plataforma de arrecadação virtual.

Do ponto de vista das práticas realizadas, as percepções registradas no caderno de campo trouxeram a sensação de um trabalho conduzido de forma tranquila pelos educadores, não foi registrada, por parte dos educadores nem dos jovens, momentos de agressividade, nesse caso acrescento aqui anotações relacionadas a um dos encontros:

Enquanto aqueciam a educadora me chama para explicar o que estavam fazendo, era continuação da semana anterior, onde cada um criou uma pequena partitura cênica, a partir de um sentimento, lembrança, e estavam desenvolvendo isso. Prometeu me explicar melhor no outro encontro. Eu assenti. Então passou do aquecimento coletivo ao que chamou de recuperação das cenas, que durou uma meia hora, onde cada um re-visitou individualmente o que havia criado. Ao terminar essa etapa, pediu que cada 
um buscasse os materiais para sua cena. E começa um alvoroço, correria "boa" onde trocavam materiais e combinavam quem colocaria a trilha sonora da cena do outro, muitas delas estavam em seus celulares.

Então começaram a mostrar suas cenas (pequenas, de 1 minuto) individualmente. No final ao invés de aplaudir estalavam os dedos.

A educadora finalizou em roda abrindo para comentários. E pediu que comentassem sobre quais cenas conversavam entre si, e anotava as sugestões. Disse precisava da colaboração de todos nos próximos encontros para encontrar essas conexões entre as cenas, para construírem uma teia, uma rede que seria um exercício coletivo, a partir dessas criações. Os educandos foram falando e ouvindo, sentados em roda, opinando sobro o que viu, sentiu de cada cena, e a relação com o mote inicial (esse eu perdi, pois ainda não estava por lá!). Termina o encontro, mais cedo por questões de manutenção do espaço, que não sei ao certo. Um grupo de alunos pega vassouras e rodo e começa a limpar o espaço [...]. (Caderno de campo, 19/03/2015).

O conjunto de referências acima mobilizadas não teve somente o objetivo de retratar os territórios interiores do IRC e o tempo e ritmo em que ocorrem as interações e relações entre jovens-sujeitos educandos e educadores e entre os jovens entre si, elas foram agenciadas também para deixar um pouco mais evidentes os processos de socialização ali concretizados, pois como defende Georg Simmel (1983 apud ALCANTÃRA JUNIOR, 2005, p. 33), a "sociabilidade é a pura forma de socialização". Assim, às outras experiências de socialização vivenciadas pelos jovens pesquisados nos espaços da família, da escola, da religião, das práticas esportivas, a proposta do IRC busca adensar a rede de sociabilidade e socialização secundária dos mesmos.

Feita essa breve descrição do IRC e de seu curso de iniciação em teatro, na continuidade nos deteremos na caracterização de cada um dos jovens - educandos - que colaboraram com o estudo.

\subsection{Retratos dos sujeitos que colaboraram com a investigação}

Nas páginas que seguem apresento uma descrição dos jovens que participaram da investigação, levando em consideração dados sócio demográficos e socioculturais - deles e de suas respectivas famílias, e também a partir de elementos que evidenciem as interações sociais e os percursos socializadores - primários e secundários - que realizaram que contribuíram para que se aproximassem, se inserissem e estabelecem relações de pertencimento com o espaço-tempo do IRC e de seu curso de Iniciação de teatro.

Antes de prosseguir na caracterização de cada um dos jovens, esclareço que nas diferentes etapas deste estudo a noção de pertencimento foi usada tal como explicada por 
Amaral (2006), que entende que aquela relação revela, tanto do ponto de vista objetivo como subjetivo, o modo como

Os indivíduos pensam em si mesmos como membros de uma coletividade na qual símbolos expressam valores, medos e aspirações. [...] Esse sentimento de pertencimento pode ser reconhecido na forma como um grupo desenvolve sua atividade de produção, manutenção e aprofundamento das diferenças, cujo significado é dado por eles próprios em suas relações sociais. [...] A sensação de pertencimento significa que precisamos nos sentir como pertencentes a tal lugar e ao mesmo tempo sentir que esse tal lugar nos pertence, e que assim acreditamos que podemos interferir e, mais do que tudo, que vale a pena interferir na rotina e nos rumos desse tal lugar. (AMARAL, 2006, p. 1).

Ao olharmos atentamente às trajetórias dos jovens percebemos que passaram por diferentes contextos socializadores nas áreas da cultura ensino e religião, cuja adesão desvela estratégias distintas de engajamento e diferentes graus de pertencimento da parte dos mesmos. Em alguns casos existe a influência dos pais e outros familiares, em outros casos, grupos de amigos ou professores contam como incentivadores para que os jovens acrescentassem o fazer teatral aos seus processos socializadores.

Ao ouvirmos as narrativas desenvolvidas pelos jovens a respeito de suas escolhas e analisando os múltiplos fatores que levaram os jovens a esse engajamento podemos perceber elementos que nos auxiliam e entender melhor a correlação desses fatores e sua combinação composta por fatores intrínsecos e extrínsecos as vontades dos jovens (REYMOND, 2003; SPOSITO, 2008). É possível também acompanhar as estratégias adotadas pelos jovens visando engajamento e manutenção do seu contato com o fazer teatral. Também é possível notar que os fazem escolhas e revertem escolhas (FABBRINNI; MELLUCCI, 1992).

\subsubsection{Andrei $^{35}, 17$ anos, branco. Nasceu e mora em Cravinhos.}

Andrei nasceu e mora em uma cidade vizinha a Ribeirão Preto, o que demanda deslocamento diário do jovem para a sede do IRC, que o faz de forma gratuita em transporte coletivo cedido pela administração local de seu município, atendendo estudantes que se movem diariamente para frequentarem a educação básica ou superior. Andrei sempre estudou em escola públicas e já tinha concluído a etapa do ensino médio quando no momento de sua entrevista.

\footnotetext{
${ }^{35}$ A fim de respeitar e garantir o anonimato dos entrevistados, os nomes dos jovens são fictícios. Respeitou-se também a autodeclaração em relação a características étnico-raciais em todos os casos.
} 
O rapaz mora com o pai, um irmão e uma irmã - essa última, irmã mais velha, não é consanguínea, pois foi adotada aos três anos de idade. Sua mãe separou-se de seu pai e constituiu nova união, na qual não constituiu prole. Andrei nos contou que sua mãe trabalha como empregada doméstica, enquanto o pai exerce a função de mecânico. Até 2015, ele não contava com experiências de inserção no mundo do trabalho.

A entrevista foi iniciada na sede do IRC, mas devido ao ruído excessivo, foi interrompida e reiniciada em uma praça próxima. O entrevistado se mostrou sempre muito solícito e firme nas respostas, gesticula vivamente e fala com ênfase quando desejava afirmar algo.

Em relação às primeiras vivências relacionadas ao teatro, o jovem diz que sua primeira experiência como espectador ocorreu durante a infância: foi uma apresentação de teatro de bonecos em um parque. Todavia, Andrei não atribuiu a essa experiência nenhum significado que poderia potencializar sua busca por processos formativos em teatro. Segundo nos disse, os fatores que teriam despertado seu interesse pela representação remontam a sua infância, apesar de isentar os pais dessa influência: "pegava as roupas da minha mãe pra imitar personagem de novela, roupas do meu pai, ficava cantando, acho que foi um estímulo meu. Meus pais não me estimularam a isso."

Em seu caso, o envolvimento mais formal com o fazer teatral se deu mediante sua participação em "oficina de teatro", iniciativa cultural gratuita promovida pelo Executivo municipal da localidade em que mora. Para ele, esse arranjo socializador e formativo tinha qualidade, porém não assegurava o aprofundamento que desejava; respostas a essa necessidade ele foi buscar em outra cidade, tentando combinar os tempos de formação do fazer teatral com a escolarização básica:

Curso bem básico mesmo, de uma vez por semana; inclusive, ele é ex-aluno do Ribeirão em Cena, e ele tentava passar um pouco do que ele sabia, claro que não chega nem perto do que eu aprendi aqui. Mas foi bem bacana a experiência com ele. [...]- Eu buscava uma aula de teatro. Eu pesquisei em sites achei várias escolas de teatro, achei inclusive o [escola de teatro], que é uma escola caríssima... [...] Aí, eu conheci o IRC, vinha visitar há uns 2 anos atrás e em 2014, eu fiz o teste.

Vim através de peças, aí ficava ligando perguntando quando tinha vagas. Aquela coisa.Primeiro só tinha de manhã, abriu turma de manhã, mas como eu não podia, eu esperei abrir turma da tarde.

Ao mesmo tempo em que participava da oficina acima, Andrei realizava atividades como ator em musicais realizados por uma academia de dança de sua cidade. 


\subsubsection{Vânia, 18 anos, branca. Nasceu e mora em Ribeirão Preto.}

Vânia é filha única e mora com a mãe, pois os pais são separados. Tem como última formação o ensino médio completo e realizou toda a educação básica em estabelecimentos públicos de ensino. Até o momento da entrevista, a jovem não contava com experiências na esfera do trabalho. Contou-nos que sua mãe trabalha como auxiliar de laboratório, não forneceu dados sobre a profissão do pai, pois afirmou não ter contato frequente com ele.

O envolvimento da jovem com o teatro se deu aos 14 anos, quando participou, por três anos, de um curso também no campo do fazer teatral em entidade privada de Ribeirão Preto, sobre o qual expressou avaliação negativa. Foi no contexto dessa experiência que ficou sabendo, por intermédio de colegas que ali estudavam, da iniciativa educativa do IRC.

Depois de algum tempo a primeira instituição pareceu não satisfazer suas necessidades, pois: "Buscava algo que tirasse da rotina e exercesse alguma coisa que pudesse ampliar meus horizontes”. Segundo a jovem, os motivos que a levaram ao Instituto é perceber que ali havia uma possibilidade de continuidade e aperfeiçoamento: “já fazia teatro há alguns anos, então o IRC serviu mais pra me... levar um pouco mais, artisticamente falando, um pouco mais de maturidade artística". Envolveu-se também em outras atividades culturais, pois já havia tentado fazer aulas particulares de violão e artesanato.

A jovem não soube identificar com precisão quais foram às influências que a levaram a optar pelo fazer teatral. Ao tentar identificar um ou mais fatores que a ajudasse a formular uma resposta, desenvolveu o seguinte narrativa:

V - Eu tentei música e artesanato, mas nada deu certo (risos). Mas, desde pequena que eu tive mais voltada pra essa coisa artística.

$\mathrm{P}$ - Mas você sabe de onde vem isso?

V - Não.

$\mathrm{P}$ - Na sua família tem alguém envolvido em alguma atividade artística?

V - Ninguém, Ninguém. A única pessoa que, na verdade, me dava esse apoio era meu avô né? Mas depois que ele faleceu, eu tive essa coisa. Acho que é por isso que eu procurei o teatro, antes eu ainda tava sendo incentivada, depois parou e eu pensei 'Opa! Vamo por minha conta, né?'[...] Na minha família não tem artistas (risos).

\subsubsection{Igor, 18 anos, branco. Nasceu e mora em Ribeirão Preto.}

Igor reside com seus pais e uma irmã; tem outra irmã mais velha que reside sozinha em outra casa. Em 2015, ingressou em curso de Licenciatura em Artes Visuais em uma 
faculdade privada. Cursou todo o ensino básico em escolas públicas. Seus pais trabalham como funcionários públicos, sua mãe atua na área do magistério, como pedagoga, e o pai é trabalhador da segurança pública, atuando como policial militar, caminho que estaria sendo trilhado por sua irmã que mora sozinha, pois ela frequenta a academia militar. O jovem trabalha eventualmente, realizando atividades de designer.

O jovem traz duas imagens como recordações de seus primeiros contatos com o teatro, uma seriam imagens de um álbum da família, onde reconheceu sua mãe em figurinos teatrais. A outra reminiscência é de uma peça teatral que assistiu no Teatro Municipal de Ribeirão Preto. Os efeitos especiais de som, relacionados a tiros de arma de fogo - tratava de uma peça que teria como personagens policiais- ficaram em sua recordação por muito tempo afirma o jovem.

P- Você lembra que peça que era?

E- Não lembro, não lembro, sei que era uma peça que um povo chegava atirando. Que eu era muito pequeno, acho que eu tinha uns 9 anos. Era o Teatro Municipal, eu acho que devia ser um cara da polícia que deu pro meu pai, porque tinha muito tiro na peça, o cara vinha com umas bombinhas atirando. Foi meu primeiro contato. Ah! e eu vi umas fotos da minha mãe que ela vestia vários personagens, e ela fez teatro também, mas bem pouco. E aí eu vi essas fotos, mas esse foi pouco contato assim na infância. Aí depois com 14 anos eu fui pro [grupo de teatro amador]. E lá eu tive contato maior.

P- Você falou que sua mãe fez teatro?

E- Sim, um pouco. Tinha várias fotos dela, vestida de homem, vestidos, muito engraçado. E aí quando eu entrei pro teatro eu falava com ela, ela dizia ah, é assim e tal, mas nunca entrou nesse assunto. Não sei, acho que ela tem um pouco de receio sobre isso.

P- Você não fala disso sobre ela?

E- Eu já tentei, mas ela sempre me corta, (risos). É muito engraçado.

P- Mas ela te mostrou as fotos?

E- Eu vi as fotos na caixa de fotos, tem uma caixa de fotos lá em casa, a gente abre a caixa de fotos e vê as fotos! (Risos)

$\mathrm{P}$ - Ter visto essas fotos te deixou curioso em relação ao teatro?

E- Acho que sim, mas quando eu entrei pro teatro eu falei, minha mãe fazia teatro, mas era só isso.

P- Tem mais algo de artístico na família?

E- Minhas irmãs, uma delas toca teclado e baixo, outra toca guitarra e violão, minha mãe toca teclado e pinta. Antes ela pintava, hoje muito pouco.

Igor não recordou de experiência relacionada ao teatro durante o período do ensino fundamental e o ensino médio. O mais próximo disso - mesmo assim não afirma ser uma experiência em teatro - é a lembrança de que costumava subir no palco existente do pátio da escola e dublar músicas que eram executadas durante o intervalo, em especial coreografias do grupo musical "Rebeldes". Ainda sobre o período escolar, afirma ter ouvido de certa professora que deveria fazer teatro, pois teria "jeito" para atuar. 
O primeiro contato de Igor com o fazer teatral deu-se no interior de um grupo de teatro amador de natureza religiosa. O jovem, que frequenta uma igreja cristã, faz questão de ressaltar que não seria um grupo caráter evangelista:

na verdade a visão do grupo era criar peças e apresentar por aí, no mundo, seculares é a palavra que seu usa. Não, não era [evangelização]. Era um meio de pensar cristão, voltado para artistas que não são da Igreja [...] era um grupo que aceitava qualquer pessoa, católico, espírita, mas o foco era levar um teatro cristão, que não agrida.

No campo das artes, o entrevistado diz ter se interessado inicialmente pela dança: "na verdade eu queria dançar também, era fissurado por contemporâneo, mas só que assim, eu sou gordo, né?" (risos) Eu queria fazer alguma coisa que mexesse com o corpo. Também nos contou que começou o teatro para ficar mais perto de uma menina da qual gostava: "vou fazer teatro pra ficar mais perto dela!Aí, me encontrei."

Foi através de integrantes desse primeiro grupo de teatro que o jovem tomou conhecimento da existência do IRC e começou a frequentá-lo, a princípio como espectador, prestigiando as peças que lá eram encenadas. Igor atribui a esse momento grande importância na sua opção por fazer teatro, teria sido a qualidade dos trabalhos ali apresentados que lhe despertaram vontade de se inserir naquele universo cultural.

Eu sempre vi as peças o IRC eu já fazia teatro, mas quando eu comecei a assistir ao sair do teatro eu percebia que eu saia de uma forma diferente, então eu percebia que eu saí de uma forma diferente. E ai eu falei nossa eu quero também fazer com que as pessoas saiam de uma maneira diferente e eu também tive na cabeça que fazer teatro é um meio de transformação.

\subsubsection{Natália, 18 anos, branca. Nasceu e mora em Ribeirão Preto}

Natália (18) mora com os pais, tem uma irmã mais velha que reside na mesma casa e um irmão mais velho que já se casou, constituiu família e mora em outra casa. A jovem concluiu o ensino médio e nunca trabalhou formalmente. Natália estudou realizou a educação básica quase que integralmente em instituições públicas, a exceção da educação infantil "maternal", quando frequentou estabelecimento privado.

O pai de Natália trabalha no ramo da construção, como pedreiro e sua mãe já foi proprietária de uma loja no bairro onde vivem, onde Natália já trabalhou como ajudante, porém, hoje em dia a família encerrou as atividades do empreendimento. A jovem afirma tentou já trabalhar fora algumas vezes, mas enfrentou resistência do pai que sempre diz a ela 
que "põe o feijão dentro de casa" para que as filhas não trabalhem e a incentiva a fazer cursos como violão e teatro.

A entrevista com essa jovem foi iniciada no foyer do teatro do IRC, mas devido a algumas interrupções dos colegas da entrevistada nos dirigimos a uma praça próxima. A princípio, a jovem teve dificuldades em responder as questões que lhe formulava, sentia-se um pouco preocupada em encontrar as palavras corretas às perguntas, o que tornou a entrevista um pouco mais difícil do que as outras, exigindo que algumas perguntas tivessem que ser reformuladas várias vezes.

Natália afirmou não ter em sua família ninguém que desenvolva atividade artística. Disse-nos que foi incentivada a fazer teatro desde pequena, pois a família percebia que ela era afeita a imitar as pessoas que via ao vivo eu pela TV.

P- Quando as pessoas da sua família diziam isso você acha que te incentivou?

$\mathrm{N}-\mathrm{Sim}$ acho que bastante,

P-Através do exemplo também?

N- Através de exemplo não, porque na minha família ninguém é artista, ninguém faz nada, ninguém é musico ou toca violão, nada dessas coisas. Fui eu a diferentezinha (risos)

Ela registrou que sempre gostou de teatro, e que gostaria de ter começado uma formação teatral há tempos, mas não tinha "dinheiro" nem idade suficientes para tanto: "Então eu queria fazer antes, mas não tive oportunidade, também não era muito de ir atrás, fui sempre de deixar vir até a mim. Ai de repente apareceu, "ah vamos lá ver no que dá". E tô aqui!”.

Entretanto, a jovem confessou que seu pai estava cansado de vê-la "sem fazer nada" durante o período vespertino e viu no teatro uma oportunidade de oferecer à filha uma atividade pela qual ela se interessasse; por saber das características e vontade da filha, foi quem a alertou sobre a abertura das inscrições para o curso de iniciação do IRC: "Então eu queria fazer antes, mas não tinha dinheiro pra pagar curso e não tinha idade pra entrar, ai eu fiz 16 e tal, e tipo esqueci, Mas passou na televisão, e meu pai disse "olha lá! Você não queria fazer?"

Em outros espaços de sociabilidade s socialização, Natália (18) teve aulas particulares de violão e, em uma paróquia da Igreja Católica, tomou contato com a música integrando um grupo musical de canto coral. Isso parece nos mostrar que nesse caso, e no caso de outros jovens, como Igor (18) e Marina (29), que ambientes relacionados à religiosidade podem 
contribuir para o contato dos jovens com os diversos fazeres artísticos, e que os jovens podem transitar entre diferentes áreas artísticas, como o teatro a dança e a música.

No Ribeirão em Cena as habilidades de canto e com o instrumento foram logos postas em prática, levando Natália a tocar e cantar inclusive em trabalhos desenvolvidos com outras turmas a qual não pertencia.

Percebemos que um dos patrimônios de Natália foi o encorajamento e apoio da família, o reconhecimento e a legitimação de seus pais daquilo que eventualmente percebiam como uma "inclinação" artística da filha, desde a infância.

\subsubsection{Nádia, 27 anos, branca. Nasceu e mora em Ribeirão Preto.}

Nádia tem 27 anos, reside com o pai, a mãe e dois irmãos mais novos que ela. Ela concedeu a entrevista em um clube da cidade, local provisório dos encontros do Curso de Iniciação de Teatro do IRC, pois as dependências físicas do Instituto passavam por reforma nesse dia. A jovem é formada em Economia em uma faculdade privada de Ribeirão Preto e trabalha em empresa de seguros.

Nádia afirmou teve contato com o fazer teatral durante o ensino fundamental e no interior de escola privada de Ribeirão Preto, instituição que frequentou da educação infantil à oitava série do ensino fundamental. Segundo ela, o aluno que chegava a oitava série dessa escola privada participava de um curso formação em teatro, com duração de um ano; tal curso integrava a proposta curricular da unidade de ensino. Nádia assinalou que o que mais a marcou foi o ato de subir ao palco, momento que lhe teria despertado uma paixão por essa arte.

Eu lembro direitinho: todos os alunos subiram... Aí, o nosso professor ficou lá na plateia e fez um exercício... Bobo! Sabe? (Risos). A gente fingiu que era uma... que tava num jardim (risos), e que nós éramos flores! Aí quando eu fiz... esse trabalhinho, eu fiz oh! (boquiaberta) Nossa! Me deu um... Um... (risos). (gesto que não sabe o que dizer). Uma coisa tão boa sabe? (risos). Daí que eu comecei a gostar

A jovem revelou que não pode continuar a escolarização básica na escola privada, tendo que se transferir para escola da rede pública de ensino onde realizou a etapa da educação média e, concomitantemente, começou a trabalhar. A entrevistada revelou que esse período não pode mais realizar nenhuma atividade relacionada à arte, pois não tinha mais tempo, e a escola onde foi estudar não oferecia possibilidade alguma nesta área; assim, foi obrigada, com certa indignação, a postergar o desejo de dar continuidade à formação teatral 
iniciada à época do ensino fundamental: "Lá não tinha nada, absolutamente, nada de nada. Nada disso... (gesto de negação enfático). Coisas que eu aprendi na $8^{\mathrm{a}}$ série, $7^{\mathrm{a}}$ série, eles estavam aprendendo lá no primeiro colegial! Nossa! (silêncio e careta!) Foi um... nada! Pfu! (risos)"

Após a conclusão do ensino médio, Nádia começou a cursar a Faculdade de Economia. Durante esse período, contou que pode fruir, em raras ocasiões, de peças de teatro, quando distribuíam ingressos aos alunos. Segundo a entrevistada, o emprego na área de seguros foi obtido graças à formação em Economia. Nádia lembra que pensou em prestar o concurso vestibular para o curso de artes cênicas, mas tal opção foi recusada por seu pai, de forma categórica:

[...] E ali acabou, né? Daí eu ficava buscando um. “Ai! Eu vou pra São Paulo pra fazer!" (risos). Antes d'eu começar a faculdade de economia eu falei pro meu pai que eu queria fazer uma escola de teatro... uma faculdade de teatro. Ai que eu queria ir pra São Paulo, morar na casa da minha tia. Ele falou assim que não, que isso não era futuro, que tinha que estudar, tinha que ter uma profissão e depois eu faria o que eu quisesse. (risos). Conclusão (risos), fiz economia... (risos). Hoje eu dou razão pra ele, se eu não tivesse essa formação eu não tinha o emprego que tenho hoje! Mas eu não desisti!

A entrevistada disse que quase se inscreveu para o curso de teatro do IRC no ano de 2013, porém teve medo de prestar a prova: "medo de não dar certo" e desistiu. No entanto, Nádia procurou outra escola particular de formação teatral existente na cidade, mas disse que não gostou do método. Por outro lado, também disse-nos que não teria condições de pagar um curso de formação teatral naquele momento. No ano seguinte (2014), Nádia ingressou no curso do Ribeirão em Cena.

$\mathrm{Na}$ trajetória que Nádia fez até finalmente realizar o "sonho de subir no palco", temos a mudança da escola privada para a escola pública a fim de concluir o ensino médio, a inserção e o ingresso na esfera do trabalho na idade adolescente, a recusa do pai para que ela pudesse prestar o vestibular para ingresso no curso de artes cênicas, a realização do curso superior em Economia, o investimento em uma carreira profissional diversa das carreiras possíveis nas artes cênicas. Todavia, esses percursos não impediram que Nádia pudesse retornasse ao fazer teatral: após concluir o projeto paterno - de ensino superior e profissão, de se deixar ser herdada pela herança (BOURDIEU, 1997) ${ }^{36}$ pode fazer a formação aspirada, desta feita, com o a complacência e aval paterno, pois não recusou o patrimônio que a figura paterna planejou transmitir-lhe:

\footnotetext{
${ }^{36}$ Pierre Bourdieu (1997). As contradições da herança. In LINS, Daniel S. Cultura e subjetividade: saberes nômades. Campinas: Papirus.
} 
Aí o meu pai me apoiou! Por quê? (risos). E minha mãe sempre me apoiou. Meu pai me apoiou porque eu já tinha terminado a faculdade, já tenho meu carro, já tinha meu trabalho. Ele vê como um lazer. Ele acha que hoje isso é muito importante pra mim... Mas ele me apoiou, creio eu porque eu já tenho tudo concluído, do ponto de vista dele, de pai. De "formei minha filha, ela já tem um carro, ela já tem não-sei-o-quê...Agora é o lazer dela".

$\mathrm{P}$ - Agora ela pode fazer?

H - Ela já tem vinte e sete anos, ela tem o lazer dela... (risos).

\subsubsection{Nicolas, 17 anos, pardo. Nasceu e mora em Ribeirão Preto.}

Nicolas tem 17 anos e é natural de Ribeirão Preto, mora com o pai e a mãe e uma irmã mais nova. O pai trabalha como feirante e pedreiro. A mãe trabalha como faxineira em uma clínica hospitalar privada cidade. O jovem que já concluiu o ensino médio trabalha com o pai na feira, sendo um exemplo da afirmação de que em nossa sociedade o trabalho também faz a juventude (SPÓSITO, 2008).

O jovem concedeu a entrevista na Universidade onde o pesquisador estuda; escolheu o local porque era mais perto de sua casa. Nicolas iniciou a entrevista um pouco lacônico, ficando mais à vontade aos poucos, mas foi a única das entrevistas na qual foi necessária a interrupção deliberada da gravação, pois o jovem se emocionou a recordar alguns momentos de sua vida, relacionados ao período escolar, os motivos serão relatados traremos em detalhes mais à frente. A entrevista foi interrompida e retomada apenas quando o jovem pediu para continuar, poucos instantes depois.

O primeiro contato com o fazer teatral foi aos 14 anos, através de amigos que o convidaram para participar numa encenação na paróquia da Igreja Católica, perto de sua moradia. Antes de ingressar no IRC Nicolas frequentou um curso pago em outra escola de teatro em Ribeirão: enfatiza que usava seus próprios recursos financeiros:

$\mathrm{N}$ - Pagava com meu dinheiro, que eu trabalhava com meu pai [...]. Trabalhava na feira [...]. Desde jovenzinho... Eu peguei o dinheiro e resolvi pagar. Tinha umas amigas da escola que faziam, falaram, faço teatro. Eu já tinha feito na Igreja e tal então eu perguntei onde vocês fazem, elas disseram no [escola de teatro ${ }^{37}$. "Vamo lá ver como que é!".

P- Quanto tempo você ficou lá?

$\mathrm{N}$ - Um ano e pouquinho

$\mathrm{P}-\mathrm{E}$ o que você não gostou.

$\mathrm{N}$ - Eu não gostei porque tinha que pagar, e era caro, ai chegou no segundo ano eu já não tava mais com tanto dinheiro, comecei a pagar minha internet. Comecei a comprar meus outros negociinhos. Aí eu saí, mas eu saí sabendo

\footnotetext{
${ }^{37}$ Escola de teatro na cidade, omitiremos aqui o nome.
} 
que tinha o IRC. Só que em seguida não rolou de entrar no IRC. Dois anos depois eu consegui. Eu sabia que ia voltar pro teatro.

Nicolas contou com o incentivo de sua prima, que frequentava o IRC, e contou para ele como eram as atividades lá desenvolvidas. Ao se interessar pelo que ouviu sobre o Instituto, resolveu ingressar no curso por ele oferecido, apesar das consequências que lhe trariam: precisaria trabalhar menos e assim ganharia menos dinheiro. Além do fato de que, se quisesse levar o curso até o final, teria que manter-se assíduo por dois anos. Para ele, um desafio manter-se tanto tempo em uma atividade, pois confessou que sempre parava qualquer atividade iniciada, pois logo dela se desinteressava, desanimava: "Ah, cursos de computação, cursos de inglês, nada que tenha arte. O teatro foi a única coisa que eu comecei e terminei" Em suas palavras:

Olha, na verdade, eu descobri o IRC pela minha prima. A primeira vez que eu fiz teatro foi na Igreja, e eu gostei da sensação e tal. Depois, eu entrei no [escola de teatro na cidade], fiquei lá um tempo, mas não gostei. Depois eu fiquei sabendo pela minha prima do IRC. Mesmo sabendo das consequências que lá tinha que ficar um grande tempo. Não ia poder trabalhar direito porque ocupa bastante tempo.

\subsubsection{Marina, 29 anos, branca. Nasceu e mora em Ribeirão Preto.}

Marina nasceu e mora em Ribeirão Preto, é casada, coabita com o marido e não tem filhos. Tem formação superior em Educação Física e trabalha na área como professora, em escolas públicas do ensino fundamental e médio.

Marina relata que seus primeiros contatos com atividades artísticas ocorreram na infância: em sua casa teve desde muito cedo o contato com a música, pois seu pai é musico, nas horas vagas. Outra experiência decorre do seu envolvimento com a dança sobre a qual conto, sorrindo, uma pequena experiência de criança:

Quando eu era criança era o balé, né? Quando eu tinha, acho que cinco anos, eu peguei a bicicleta, fui numa escola de balé, há uns sete quarteirões, sem minha mãe saber, eu tinha uns cinco anos!

"Moça como é que faz pra fazer balé aqui?"

Aí a moça: "Ué! Mas cadê sua mãe?"

"Eu tô sozinha..."

Daí a moça: "quê que você tá fazendo aqui sozinha (risos) e não sei o quê..." E me deu um folheto: "Entrega lá pra sua mãe."

Daí eu fui! Fazer a primeira aula, daí nossa adorava. Ai a gente mudou pro centro, eu fazia no SESC. Nossa, adorava, e dançava, e sempre tive facilidade e tal. 
Em adição à experiência da formação em balé, Marina fez referências à outra experiência, desta feita no interior de uma Igreja evangélica, local onde afirmou sempre ter dançado e cantado. Já casada, em associação com o marido, estudante de Música em uma faculdade em Ribeirão Preto, organizou um coletivo de danças e cantos brasileiros. Grupo, segundo ela, que sofre discriminação e é alvo de "preconceito dentro do meio evangélico"

Ao mesmo que tempo que mirou a carreira da Educação Física como educação superior e possibilidade de inserção no mercado de trabalho a partir de uma atividade que lhe desse satisfação pessoal e profissional, essa jovem admitiu que também alimentava o desejo de realizar um curso de teatro, mas para que o pudesse frequentar de forma tranquila da forma que desejava. Decidiu que deveria ter um emprego estável. Ao tomar essa decisão precisou cumprir algumas etapas, agindo sobre as circunstâncias que limitavam seus projetos e ações: primeiro, passar e se formar no Curso Técnico de Secretariado, de modo a se inserir na esfera do trabalho, conquistando um emprego que lhe oferecesse uma independência monetária, e garantisse os recursos e suportes necessários para acessar, frequentar o Curso de Educação Física, em instituição privada de ensino superior.

A trajetória de Marina então pode ser descrita passo a passo, do secretariado à faculdade, da faculdade ao emprego público, do emprego público a possibilidade de realizar a oficina de teatro.

Pra mim, o corpo sempre foi fundamental, minha infância foi muito ativa, eu sempre dancei, fazia dança, fazia natação, fazia vôlei, eu vivia no SESC aqui... [...] A tarde inteira, fazendo vôlei, natação e eu me inspirava nos professores... Falava: 'nossa, um dia quero ser professora de Educação Física'... [...] Na verdade, pra chegar na faculdade, eu ainda fiz secretariado! (risos). Fiz um curso técnico de secretariado. Todo mundo sabia que eu queria fazer educação física, só que eu não tinha dinheiro pra pagar e na época não tinha PROUNI, um monte de bolsa que tem hoje, era difícil, era só rico que fazia faculdade né? Então eu fui estudar secretariado, pra conseguir um emprego melhor, pra conseguir pagar minha faculdade. Daí lá no curso técnico de secretariado todo mundo sabia que eu queria fazer Educação Física.

\subsubsection{Ivan, 17 anos, negro. Nasceu e mora em Serra Azul.}

Ivan, 17 anos, integra uma família recomposta. Os pais são separados, e ele morava com o pai e a madrasta e dois filhos da nova união do pai. A mãe, que também constituiu nova união, teve outros dois filhos, que se juntaram aos três da união anterior com o pai de Ivan. No momento da entrevista, Ivan cursava o segundo ano do ensino médio, em uma escola 
pública estadual. Combinava os ritmos da escolarização com os do trabalho, atuando como educador de informática, em um projeto da Prefeitura Municipal de Serra Azul.

O seu primeiro contato com o teatro deu-se no interior da escola pública, não como espectador, mas através de uma apresentação sobre a obra de Monteiro Lobato, O Sitio do Pica-Pau Amarelo, tinha 7 anos de idade e afirmou que guarda na lembrança o fato de gostar muito da música da "bruxa" e ficar com ela" na cabeça" por muito tempo.

O jovem relata que não há envolvimento algum tipo de atividade artístico por parte de pessoas de sua da família nem incentivo; o jovem levou seu pai e madrasta ao teatro e garante que esse foi o primeiro contato de ambos com o teatro. Sobre esses fatos faz a seguinte avaliação: "Uma coisa que percebo: meus pais, eles ao lêem, eles não têm esse hábito, eles não tem o hábito de ter contato com leitura e cultura... Eu também não tenderia a ter se não fosse o teatro."

Ivan afirmou que a primeira oficina de teatro da qual participou foi-lhe apresentada pela diretora de um grupo de formação teatral da cidade onde mora, vizinha a Ribeirão Preto. A diretora do grupo de teatro foi pessoalmente à escola onde Ivan estudava e, passando de sala em sala, fez a divulgação do curso. O jovem afirmou ter sido tocado fortemente pelo desafio proposto por aquela senhora: “Aí a professora chegou na sala pra fazer a divulgação desse projeto e ela falou a seguinte frase, que eu lembro até hoje: "se você é aquela pessoa que tá com medo ou tá com vergonha, acha que não vai ter aquela desenvoltura legal pra fazer teatro, é você que eu quero lá."

Tratava-se de uma iniciativa do poder público municipal e o rapaz, que época contava com 11 anos de idade, continuou nessa iniciativa até completar idade suficiente para ingressar no IRC, cuja existência foi apresentada por colegas e pela professora do curso de teatro que realizam em Serra Azul: "Então, ela me falou que seria uma linha diferente da qual estava acostumado. Daí eu fui gostando, esse é o principal motivo de eu estar aqui, a indicação e a vontade de querer fazer".

\subsubsection{Alexander, 19 anos, negro. Nasceu e mora em Ribeirão Preto.}

Alexander mora com o pai, uma irmã mais velha, dois irmãos mais novos e a avó. Sua mãe faleceu quando ele tinha 7 anos de idade. Concluiu o ensino médio e atualmente trabalha como atendente em uma pastelaria, no centro de Ribeirão Preto.

O jovem afirmou que sempre gostou do teatro e que seu primeiro contato com esta manifestação artística ocorreu quando tinha 11 anos de idade, e deu-se por intermédio de uma 
de suas irmãs, no interior da Igreja Cristã Pentecostal que frequentou durante boa da infância e adolescência.

A princípio vinculou-se ao que denominou de "ministério de dança", mas tão logo teve conhecimento da existência do "ministério de teatro", mudou de opção. A partir dessas experiências, associou-se a um coletivo de danças e teatro que reunia membros de várias Igrejas evangélicas, até chegar a conhecer o trabalho do IRC por uma amiga. Nas palavras do entrevistado:

Foi na igreja. Quando eu entrei na Igreja, com 11 anos. Tinha um ministério de dança. Porque até então eu gostava de dança, eu já tive fases. Já fiz dança, natação, balé, judô, já fiz de tudo. Aí teve um momento que eu goste de dança. Eu era aquele irmãozinho que gruda no pé da minha irmã! Ela entrou na Igreja, eu entrei na igreja por conta dela. 'Vou também!' Onde ela vai, eu quero ir. Ela entrou no grupo de dança, aí eu quis também entrar no grupo de dança. Mas naquele tempo não podia, homens. Era só mulher. Aí eu entrei no infantil que podia qualquer pessoa e tal. Aí, a líder lá me viu e me chamou pra uma dança; mas eu não ia dançar especificamente, até então eu dançava com as criancinhas lá, e ela precisava de alguém pra fazer uma dança que tinha... teatro, misturado. Aí as meninas dançavam e eu a fazendo teatro. Aí eu gostei. Depois eu descobri que tinha o ministério de teatro, grupo eles falam ministério, lá. Aí eu entrei tão fundo, tão fundo que eu queria fazer mais. Eu descobri outro grupo que é de várias Igrejas que fazem esse movimento, aí eu entrei. Foi onde eu conheci a Bianca, ela era líder desse grupo que pegava gente de várias igrejas pra fazer evangelismo. E ela faz teatro no Ribeirão em Cena.

Antes de entrar no Ribeirão em Cena o jovem frequentou por seis meses um curso pago também de teatro, em escola particular da cidade, porém não gostou da metodologia de trabalho que encontrou, pois para o jovem o curso era "muito limitado" em suas propostas.

Sobre as razões que o levaram ao Ribeirão em Cena: "a princípio foi a questão da timidez né? Geralmente todo mundo começa: ah eu vou fazer teatro porque eu quero... deixar de ser tímido e tal... a princípio [...] aí fui vendo que hoje o teatro é uma coisa que me acrescenta muito pessoalmente".

\subsubsection{Sofia, 21 anos, branca. Nasceu e mora em Ribeirão Preto.}

À época da entrevista, Sofia estava no segundo ano do curso de Psicologia em uma faculdade particular. As etapas da educação básica a jovem as frequentou em diferentes estabelecimentos privados de ensino.

A mãe é professora de português em escola pública, e o pai é farmacêutico, trabalhando em uma universidade privada. Sofia nunca exerceu atividade laboral. A jovem 
tem dois irmãos: um mais velho e um mais novo, ambos em estudando em universidades públicas e morando em outros municípios do estado de São Paulo.

As primeiras lembranças que tem em relação ao envolvimento com o teatro remontam a um tempo em que estava em curso de ginástica rítmica, quando criança, e depois a primeira experiência de iniciação teatral na escola de ensino fundamental:

Vixe! (risos) Quando eu era bem pequenininha, eu não sei quantos anos eu tinha, eu fazia ginástica rítmica na [faculdade privada], e aí a gente fazia as coreografias, e a minha coreografia era a história de uma pulguinha (risos). [...] Aí eu era a pulguinha que dançava lá no meio e de repente apareciam a joaninha, aparecia a formiguinha, aparecia o besourinho... e aí isso é coisa de criança, sabe? (Risos)

P: Esse foi o primeiro contato?

S: É vendo e fazendo. É, mas eu lembro do ensino fundamental com o... droga eu nunca lembro o sobrenome dele!

Foi muito bom esse cara! Eu lembro da nossa primeira aula! Tava todo mundo sentado em roda e era pra todo mundo se apresentar. Faz aí o que você quiser e se apresenta. aí um chegava e falava (imita baixinho):'eu sou fulano'. Aí outro dava uma cambalhota e gritava eu sou fulano! e acaba a apresentação ele dava aula teórica- isso no ensino fundamental - eu lembro.Tinha uma lousa no tatame de judô e uns espelhos porque lá também tinha aula de... e tinha uma lousa de pincel atômico, ele desenhou o palco as luzes, e aí ele começou a mostrar o ângulo que a gente devia ficar no palco, pra platéia poder nos enxergar, que não poderia ficar de costas, de ficar em diagonal, não totalmente de perfil..... [...] Nossa o cara, era muito bom!

Segundo Sofia, a "arte está na família", pois seu irmão estudava música em uma universidade pública, e a cunhada, artes cênicas, ambos na UNICAMP.

Eu já tinha pensado em fazer ela antes, mas eu não tinha tempo, por causa da faculdade. Então, esse ano foi que eu me matriculei em poucas matérias e diminui um pouco a carga horária da faculdade pra que eu pudesse fazer o curso de teatro. [...] Desde pequena, eu já tinha contato com o teatro, logo depois o meu irmão mais velho... isso foi tudo um incentivo, o meu pai ele já tinha me colocado no...curso de música, curso de dança e depois na escola, no ensino fundamental eu comecei a fazer um curso de teatro. No ensino médio eu comecei a fazer outro curso de teatro, tudo na própria escola.

No ensino médio, em escola privada, a jovem envolveu-se novamente com processos formativos na área do de teatro. Já na faculdade, ela ingressou em um grupo de alunos envolvidos com o fazer teatral, liderado por um jovem que estudara essa modalidade artística em instituição cultural privada.

Como a jovem não exerce atividade remunerada, contou com um constante investimento dos seus pais em sua formação, desde sua permanência em instituições de ensino escolar que tinham em seus currículos atividades relacionadas à arte, até a possibilidade que a 
jovem teve de participar de outras instâncias não escolares em diversas modalidades artísticas e esportivas, como música, ginástica-rítmica, aikidô e caratê.

Por outro lado, ao optar pela entrada no IRC, Sofia afirma que não teria condições no momento para arcar com despesas relacionadas a um curso de teatro. Isso teria sido, de certa forma, uma estratégia da jovem em exercer sua vontade, mesmo sem apoio financeiro dos pais e acrescentar mais essa experiência em teatro aos seus processos de socialização e ao rol de suas experiências artísticas.

\subsubsection{Olga, 20 anos, branca. Nasceu em Porto Velho. Mora em Ribeirão Preto}

Olga nasceu em Porto Velho, Rondônia, e mudou-se para Ribeirão Preto há dois anos. Concluiu o ensino médio e mora com os pais. Estudou o ensino fundamental em escolas privada e o ensino médio em estabelecimentos público de educação. A mãe é funcionária dos correios e o pai trabalha no setor de aviação. A jovem trabalha meio período em uma agência imobiliária.

A jovem relatou que ao chegar a Ribeirão Preto quis procurar o teatro, pois "era uma coisa que eu queria muito desde criança, era um dos sonhos que ficou" Ela revelou que desde muito jovem tinha vontade de representar personagens, mesmo antes de assistir alguma peça de teatro, e que esse desejo aumentou, quando começou a fruir mais intensamente das atividades teatrais oferecidas pelo SESC em Porto Velho.

No entanto a única possibilidade encontrada na cidade onde vivia era uma unidade do SESI, que ficava muito distante de sua casa, o que a fez desistir.

Ao mudar-se para Ribeirão Preto contou com a ajuda de sua mãe para encontrar um curso de teatro, teria inclusive sido a mãe de Olga a ligar para o instituto para pedir informações, pois a jovem sentia-se constrangida ao falar ao telefone:

$\mathrm{R}$ - Eu sempre insisti em ser atriz, eu achava uma coisa muito interessante. Eu falava sempre que queria fazer teatro. Eu vi no SESI que era perto da minha casa, mas era uma vez por semana, mas o horário não dava. E ela achava que era uma coisa que como de costume eu ia começar e não ia terminar, eu ia perder o interesse.

Curso de inglês, tinha vontade de aprender outro idioma, parei. Basquete que eu achava muito legal. Eu acho muito legal, eu parei! (risos) Natação. Vai perdendo o interesse das coisas.

$\mathrm{R}$ - Ela [a mãe] que achou o IRC! [...]Ela ligou... [...] Ela ligou pra perguntar, e disse:'liga lá, pra você saber mais!'[...] Liguei, soube do dia da inscrição e vim, só que eu achei que nem tinha passado (Risos). 
Quando perguntamos à jovem sobre atividades relacionadas ao teatro no interior dos estabelecimentos de ensino escolar que frequentou, a jovem afirmou que não teve nenhum contato com o teatro. Porém, essa pergunta fez com que a jovem recordasse de uma experiência envolvendo o ambiente religioso: sua participação em uma encenação realizada por uma Igreja Católica de uma peça na qual ela representou, relata que teve medo e ao mesmo tempo gostou da experiência

Talvez tenha sido na Igreja, que eu fiz alguma coisa... [...] Tem essas encenações, e eu participei de uma: não falando, mas achei legal. [...] Era daquele, filho pródigo. Eu era uma das mulheres que seduziam ele. Professora de catequese que me chamou, e era muito tímida, eu nem imaginava que iria fazer, por isso não conseguia as coisas. Eu falei pra ela que não queria nem falar. Aí ela falou: 'não se preocupa, você só vai dançar... '. Pra mim, era difícil isso... Eu achava legal, mas tinha vergonha, tinha medo. Fui encarar aqui.

\subsubsection{Lucas, 17 anos, branco. Nasceu e mora em Ribeirão Preto}

Lucas mora com os pais em Ribeirão Preto, sempre em escolas privadas e no período que concedeu a entrevista cogitava em mudar-se para São Paulo, pois fora aprovado em Licenciatura em Teatro na UNESP. Seus pais são professores universitários. A entrevista com o jovem foi realizada por sua sugestão uma sorveteria próxima ao IRC.

Esse rapaz disse-nos que tem algumas experiências do fazer teatral, como componente curricular, na escola de ensino fundamental; no SESI, frequentou curso livre de teatro. Afirmou que sempre teve vontade de fazer teatro e que essa é a profissão que escolheu "porque a gente precisa de teatro precisa de cultura, de verdade".

Lucas foi apresentado ao Ribeirão em Cena, por uma professora de português que the deu ingressos para ver uma peça naquele espaço. Antes disso o jovem passou por outras experiências relativas ao fazer teatral, em sua maioria no próprio ambiente escolar, nas diferentes instituições privadas de ensino que frequentou: "Eu sempre tive um pouco ligado ao teatro, porque tinha teatro na minha escola, meu pais me levavam pra ver teatro. Ele mesmo fez teatro quando jovem, então eu sempre tive meio ligado ao teatro ”

O entrevistado afirma que a experiência teatral e as atividades lúdicas que encontrou no ambiente escolar foram se tornando escassas com o progredir dos anos, desaparecendo por completo na fase mais preparatória para o vestibular. Em sua opinião o teatro ali era visto como algo inferior. No entanto, não desistiu de ser ator e teve a ideia de fazer teatro e ser advogado, "por não ter coragem”: "Lá no (colégio privado) eles formatam a cabeça da pessoa e ela tem que fazer direito ou medicina. Sempre gostei de humanas então quis fazer direito” 
Isso fez com que, ainda durante a etapa do ensino médio o jovem entrasse em um curso de serviços jurídicos, em instituição pública estadual, mas, revelou, terminou "por terminar": "a gente aprende as leis que devem ser, como deve ser a política, e no mundo real isso não acontece [...], que juízes não tratam dessa forma, não é imparcial ”

Após esse período Lucas passou ainda a frequentar um curso livre de teatro no SESI, porém em sua opinião uma aula semanal era muito pouco, queria mais: “É fraco pra quem quer seguir carreira. E muito bom, a professora é muito boa, eu gosto muito da Bia (educadora, nome fictício). Mas pra quem que seguir, uma vez por semana, duas horinhas é muito pouco."

O caminho das escolhas de Lucas até o IRC teve momentos de engajamento, reflexões a respeito dos significados educativos do teatro. A proximidade dos pais do jovem com o teatro, os apoios recebidos do círculo familiar fizeram com que ele tivesse, desde a infância, contato com o universo artístico do teatro, razão pela qual se envolveu com processos formativos do fazer teatral, na escola de educação básica, no SESI e, finalmente, no IRC.

A escolha pelo Ribeirão em Cena deu-se porque o jovem assistiu algumas peças levadas a efeito por grupos no Instituto e disse que ficou positivamente impressionado:

Eu escolhi o Ribeirão em Cena porque eu vi algumas peças deles e achei fantástico, e eu vi o trabalho deles como escola e vi que ia realmente me colocar em algum lugar... Mas, eu nunca tinha ouvido falar do IRC [...] Mas, eu entrei no IRC porque tinha esse pensamento de fazer teatro como hobby [...] Mas, por eu ver muitos trabalhos bons, eu resolvi entrar e me apaixonei pelo teatro, e decidi que quero fazer isso como vida!!!

\subsection{A montagem de uma fotografia do coletivo}

As descrições acima permitem afirmar que a grande parte dos jovens que contribuíram com a pesquisa são filhos e filhas de famílias trabalhadoras - como pais e mães ocupados em atividades manuais, técnicas e intelectuais (professores/pesquisadores).

Do ponto de vista do mais alto nível de escolarização atingida, todos passaram pelo ensino médio e apenas um deles ainda frequentavam esta etapa de escolarização, no momento da entrevista; alguns estavam ingressando no ensino superior e duas jovens mulheres já tinham concluído este nível de educação, tendo conquistado o título universitário e, por seguinte, as prerrogativas e direitos que ele confere. 
Em relação à maior grau de escolaridade atingida por pais e mães dos entrevistados, o que constatamos é que onze deles ultrapassaram o nível de escolaridade atingido pelos progenitores. A exceção seria Lucas (17), pois seus pais são professores universitários.

Assim, mesmo com alguns contrastes, é possível afirmar que os jovens que grande parte dos jovens que contribuíram com o estudo integram famílias nucleares, parentais, outros pertencem à famílias mono parentais ou recompostas. Mesmo que não tenha sido possível levantar dados sobre a renda mensal familiar de cada um deles, o que se pode constatar - pelo nível de escolaridade de integrantes de suas famílias e a ocupação de seus pais e mães, é que eles pertencem grupos familiares posicionados em distintos estratos das classes médias urbanas de Ribeirão ou de cidades da região.

Apenas Lucas (17), Andrei (17), Sofia (21) e Vânia (18) não contavam com experiências na esfera do trabalho - formal ou informal, e encontravam-se vivendo a juventude como possibilidade de preparação, experimentação, exploração de escolhas e reversão de escolhas. Os demais viviam a fase juvenil em diferentes situações: estudantestrabalhadores e alunos do instituto, outros ou apenas trabalhadores e alunos de teatro.

Todavia, diante deste quadro, e considerando o tema da "independência" juvenil, tal como exposta por Singly (2004; 2008), é possível assinalar que apenas Marina (29) a tinha conquistado, pois concluiu o ensino superior, atua como profissional concursada na área da docência do ensino fundamental mantinha união conjugal estável e morava com o cônjuge. Em relação aos demais, pode-se dizer que a partir de suas narrativas, viviam a juventude sob proteção financeira de suas respectivas famílias, e ainda sob estatuto de "filhos" ou "filhas de", ainda não tinham reunido as condições concretas para reivindicarem "o direito à herança" e os "privilégios da transmissão".

Quanto aos movimentos que os conduziram ao curso de iniciação em teatro do IRC uma prática cultural, os excertos das entrevistas que os jovens nos concederam explicitam que a aposta formulada guarda relações com histórias dos processos de socialização primária e secundária que viveram, seja no círculo social familiar, seja na escola de ensino fundamental e médio ou em diferentes esferas religiosas de base cristã - católica ou evangélica, espaçostempos ou instituições que pautam-se por "propósitos e princípios distintos", mas que coexistem e produzem uma certa "interdependência" nas experiências dos indivíduos.(SETTON, 2002, p. 109).

Sobre as histórias dos processos socializadores que os indivíduos experimentam no círculo familiar e escolar lembra-nos Setton (2010), com base em Pierre Bourdieu, que 
aqueles círculos são responsáveis por produzirem, reproduzirem e difundirem "disposições de cultura". Desta maneira, a família, como instância de socialização primária, é:

responsável pela transmissão de um patrimônio econômico e cultural. É nela que a primeira identidade social do indivíduo é forjada [...]. De origem privilegiada ou não, a família transmite para seus descendentes um nome, uma cultura, um estilo de vida moral, ético e religioso. Não obstante, mais do que os volumes de cada um desses recursos, cada família é responsável também por um amaneira singular de vivenciar esse patrimônio. (SETTON, 2010, p. 24).

Por sua vez, quando trata da experiência religiosa, Setton (2010), recuperando clássicos do pensamento sociológico (Èmilie Durkheim e Max Weber), para afirmá-las como "espaços de produção de símbolos e, portanto, produção de comportamentos e crenças", tanto individuais como coletivos. Assim, ao identificar a experiência e a concepção de praticas culturais tal como definidas por Pierre Bourdieu, ter-se-ia que elas, inclusive as religiosas, seriam:

fenômenos que se correspondem, pois têm raízes na natureza humana de produzir sentidos e estabelecer as relações e a organização internados grupos. [...] A religião, como toda pratica de cultura, seria constituída por fenômenos que oferecem espaço para empreender o diálogo entre indivíduo e sociedade, mais explicitamente, as práticas de cultura como espaços de entendimento das relações estabelecidas entre mundo material (estruturas objetivas) e mundo simbólico (estruturas mentais /subjetivas) e as diferenças intergrupais. (SETTON, 2010, p. 30).

Ao considerar as referências acima, no capítulo seguinte daremos atenção às formas como os jovens interagiram com os conteúdos dos percursos socializados internalizados no interior dos espaços da família, da escola e das práticas religiosas, para apostarem no curso de iniciação teatral do IRC e quais as foram os efeitos socializadores daquela prática cultural em suas experiências individuais, sobretudo quanto ao desafio conquista de autonomia em relação ao mundo adulto. 


\section{OS JOVENS E O CURSO DE TEATRO DO IRC: ENFRENTAMENTOS, CONTRIBUIÇÕES E PLANOS DE FUTURO}

O teatro educa, se entendemos por educar a descoberta e utilização de formas e meios de apoio para o desenvolvimento do ser humano em direção a vida autônoma e consequente, para a sociedade de que seja membro.

Joana Lopes ${ }^{38}$

Nesta seção me deterei na exposição e análise de três dimensões das experiências dos jovens que se engajaram no Curso de Iniciação Teatral do IRC. A primeira diz respeito às situações de tensão, conflito e negociação que alguns dos sujeitos tiveram que enfrentar com a alteridade - geralmente um integrante da família de origem, para se inserirem e frequentarem àquele curso de educação não escolar.

Outra dimensão considerada tem por referência as contribuições que Curso do IRC deu aos processos de socialização, sociabilidade, independência e autonomia dos jovens, processos que tem relações diretas com movimentos de tornarem-se indivíduos nas condições históricas e sociais em que estão imersos. Por fim, trataremos dos planos de futuro que os jovens formulam tendo em conta as contribuições daquela iniciativa socializadora e educativa.

No processo de seleção e análise dos elementos contidos nas narrativas relativamente às três dimensões acima indicadas, nos guiamos pelos aportes conceituais destacados no Capítulo I deste texto, sobre juventude e jovens, socialização, educação não escolar e processos educativos do fazer teatral, e, ainda, levando em conta as reflexões de François de Singly $(2004$; 2005) quanto ao desafio que os jovens contemporâneos devem enfrentar visando à conquista da independência e da autonomia em relação ao mundo adulto.

\subsection{Os jovens e o fazer teatral: tensões, resistências e incentivos com/de membros da família}

No capítulo anterior, na caracterização de cada um dos sujeitos deste estudo, nos preocupamos em registrar os efeitos indutores positivos ou negativos que as interações sociais e os processos socializadores que experimentaram nos espaços da família, da escola de educação básica, de práticas religiosas (católicas ou evangélicas) e também em círculos de amizade, exerceram na escolha e acesso do Curso de Iniciação do IRC.

\footnotetext{
${ }^{38}$ Joana Lopes, Pega-teatro, 1989, p. 21
} 
Podemos afirmar que os relatos que os jovens formularam sobre a ação e visão de determinados atores daqueles círculos sociais sobre o acesso e frequência aquela iniciativa educativa e cultural apresentam similaridades e diferenças. Quase todos os jovens internalizaram valores culturais e criaram disposições favoráveis a busca e inserção em cursos do fazer teatral no interior do círculo de relações primárias, mas nem todos tiveram apoios e incentivos de integrantes da família para realizar a iniciativa do IRC; em alguns casos, o movimento que os levaram ao engajamento naquela proposta educativa gerou tensões ou conflitos com membros do grupo familiar - em especial os pais, exigindo dos jovens capacidades para negociar ou encontrar alternativas para concretizarem o intento desejado. Tais situações ocorreram, sobretudo com aqueles jovens que ainda coabitam com os pais e irmãos, devem obediência a autoridade do pai ou da mãe, por não terem conquistado o estatuto da "desfiliação", de modo a assumirem o "inventário da herança ou da transmissão". Assim os pais não deixaram de lembrar-lhes que uma de suas dimensões identitária era a de ser filho ou filha de (SINGLY, 2004, p. 111).

Sobre a situação acima, observou também Bourdieu (1998) que a "instituição do herdeiro e o efeito de destino que ele exerce', mesmo em sociedades diferenciadas e complexas, ainda são atribuições exclusivas da palavra do pai ou da mãe", pois eles são os "depositórios da vontade e da autoridade de todo o grupo familiar" (BOURDIEU, 1998, p. 231). Dessa forma, a família como

Matriz da trajetória social e da relação a essa trajetória, portanto das contradições e duplas vinculações (double binds) que nasceram especialmente, das discordâncias entre as disposições do herdeiro e o destino encerrado em sua herança - a família é gerado de tensões e contradições genéricas (observáveis em todas as famílias, porque ligadas à propensão a se perpetuar) e especificas (variando, especialmente, segundo as características da herança). (BOURDIEU, 1998, p. 231)

No interior da família, quanto à transmissão da herança à posição do herdeiro, Bourdieu (1998) chamou atenção para o lugar e papel desempenhado pela figura do "pai", pois ele:

é o sujeito e o instrumento de um 'projeto' (ou melhor um conatus) que, estando inscrito em suas disposições herdadas, é transmitido inconscientemente, em e por sua maneira de ser, e também, explicitamente, por ações educativas orientadas para a perpetuação da linhagem (o que, em certas tradições, é chamada 'a casa') (BOURDIEU, 1998, p. 232, grifo nosso). 
Em nosso estudo, exemplos de "tensões e contradições" que pais e filhos podem experimentar o processo de formação do herdeiro e de transmissão da herança, foram claramente explicitados pelos relatos de Nádia (27), Alexander (19) e Igor (18).

A respeito das tensões vividas e negociações realizadas com o pai, narrou Nádia:

antes de eu começar a faculdade, eu falei para o meu pai que eu queria fazer uma escola de teatro... uma faculdade de teatro. [...] Ele falou [...] 'não!'. Isso não era futuro, que eu tinha que estudar, tinha que ter uma profissão. Depois eu faria o que eu quisesse. Conclusão, fiz a faculdade [de economia]...

Após a interdição da figura paterna e depois que ingressou no curso superior, inseriuse na esfera do trabalho e adquiriu um "carro", e conquistou certa independência financeira, Nádia pode concretizar o projeto de inserir-se em curso de formação teatral, aspiração nascida na infância que perdurou até a fase da juventude, neste momento se deparou com veredicto distinto do pai, que agora lhe concedia certo "apoio" à concretização do "sonho de subir no palco", pois entendido por ele como uma prática de "lazer":

Aí o meu pai me apoiou! Por quê? (risos). Minha mãe sempre me apoiou. Meu pai me apoiou porque eu já tinha terminado a faculdade, já tenho meu carro, já tinha meu trabalho. Ele vê com um lazer. Ele acha que hoje isso é muito importante pra mim... Mas ele me apoiou, creio eu, porque eu já tenho tudo concluído, do ponto de vista dele, de pai: 'formei minha filha, ela já tem um carro, ela já tem não-sei-o-quê...Agora é o lazer dela.Ela já tem vinte e sete anos, ela tem o lazer dela...' (risos).

No caso de Sofia (21), assim como para Nádia , a disputa também vem ocorrendo com o pai, que a incentivou na escolha pelo curso de formação teatral, porém reclamava por maior atenção da filha, e por uma presença mais constante em casa, deixando transparecer questões de socialização diferencial do gênero: "eu sou a única que ficou em casa. [...] Eu não paro em casa, então ele fica super carente. E a minha mãe também não fica em casa. [...] Então por um bom tempo, ele ficava: 'ai, quando é que isso vai acabar'? Você não pode chegar mais cedo?’.

Sofia revelou que o processo de "desfiliação" está em curso e reforçou seu esforço pela conquista de certa autonomia: "eu entendo a carência do meu pai, mas eu não posso parar minha vida também.”.

Situação mais tensa e conflitiva, envolvendo a subordinação do filho em relação aos projetos do pai, têm-se no depoimento de Alexander (19), quando narrou sobre os embates que enfrenta com a figura paterna, um trabalhador manual - encanador, que nunca o apoiou em relação às artes e ao curso: 
Meu pai não apoia. [...] Ele fala que desde criança você tem que trabalhar, [...] trabalhar, trabalhar, trabalhar. [...] Quando eu falei pra ele que eu tava fazendo teatro, já teve dia de eu sair de casa, de eu ter brigado com ele. Ele já chegou a me bater e tal, porque eu tava a fim de ir pro teatro. Ele não apoia isso e, querendo ou não, isso gera medo. Meu pai odeia teatro.

Se em função das imposições paternas, Nádia cedeu e cumpriu o projeto do pai, Alexander, diante de situação relativamente semelhante, deu encaminhamento diverso, ao de Nádia: o rapaz ampliou e diversificou seu processo de socialização secundária, integrou-se à esfera do trabalho, antes de ingressar no ensino superior, para realizar um projeto que é de sua autoria. Segundo argumentou, ele fez uma espécie de "troca" com o pai: "não queria parar o teatro! E então meu pai não ia parar de pegar no meu pé, se eu não trabalhasse. Tipo uma troca, sabe? Ele não queria me dar dinheiro mais pra pegar ônibus. Tinha que ficar pegando com a vó, com a irmã, com a tia"

No caso de Igor (18), as resistências familiares provêm tanto do pai como da mãe, em virtude da visão que ambos partilham sobre o teatro e o fazer teatral, os pais comungam de uma única visão de "homem", "indivíduo" e "virilidade”, e também dos mesmos princípios religiosos, como membros de Igreja Cristã neo-evangélica. De acordo com o jovem:

O começo é muito difícil de fazer teatro, quando eu me deparei com esse processo... Eu encontrei uma coisa tipo assim, familiar, tipo meus pais são cristãos, e para eles o teatro é um meio homossexual, sabe? Então, quando eu fui para o teatro, eles tinham medo de que eu me tornasse homossexual. Eu me deparei muito com isso, mais a meus pais começaram a ver as apresentações e melhorou um pouco, mas ainda não concordam muito. Isso me deixa frustrado, às vezes me desmotiva muitas vezes... Mas, é o que eu gosto!

E para reforçar as resistências e "angústias" encontradas no meio familiar, o rapaz discorreu brevemente sobre as antipatias da mãe: “[Ela] já chegou a falar, esse meio tem muito homossexual, ela tem medo que eu me contamine (risos)."

Neste último caso, as concepções de homem e de homossexuais que os pais de Igor compartilham, assim como as relações que eles estabelecem entre aquelas duas figuras, o teatro e o fazer teatral - práticas culturais estruturadas pelas emoções nos permitem estabelecer relações com as observações feitas por Martuccelli (2007) sobre as imagens de "indivíduo soberano" e de "virilidade" criadas pela modernidade e ainda amplamente difundidas e aceitas, em diferentes círculos sociais. Segundo o pesquisador:

a ficção da 'virilidade' é assombrosa: definida amplamente por atitudes corporais e pela coragem física, ela não tem, em sua imagem mais ideal, nem corpo nem emoções. Ou melhor, ela é estritamente definida pela superação 
de um e de outras. É isso o que marca a sua especificidade, o que estabelece sua diferença com as demais [ficções], e não somente em relação às mulheres, mas também aqueles que se mantêm prisioneiros de seus corpos e de suas emoções (as crianças, os homossexuais, os selvagens, os preguiçosos), mais ou menos expulsos do estado de 'natureza', o exótico, a imaturidade, na verdade todos os indivíduos considerados incapazes de terem-se por sim mesmos (MARTUCELLI, 2007, p. 93; tradução livre).

Não por outras razões, diante das resistências e receios de seu pai e sua mãe, quanto ao seu envolvimento com o teatro e fazer teatral, e os exercícios que ele desenvolve em função do curso, disse-nos Igor sobre sua juventude, "angústias" e "anseios": "Eu pude perceber como eu sou inconstante, talvez por minha idade não sei... Mas isso me fez enxergar minhas angustias e anseios; me impulsionou, mas me fez pensar, puxa, não preciso ser assim, isso não é legal!"

Contudo, não são apenas tensões, resistências e conflitos entre os jovens e seus pais, em relação ao envolvimento com o curso do IRC, o que verificamos nos depoimentos que nos concederam; em alguns casos foi possível também identificar pais que, sem abrirem mão do papel da autoridade, incentivaram os jovens a aprofundarem o envolvimento com aquela proposta educativa, caso, por exemplo, de Olga (20), cuja mãe ajudou a filha a encontrar um curso de teatro na cidade, de Natália (18), cujo pai foi o responsável, ao ver uma chamada televisiva sobre o curso de teatro e avisá-la e de Lucas (17) que explicitou incentivos objetivos de membros de sua família, inclusive seu pai:

meus pais me levava pra ver teatro. [...] Meu pai e minha mãe sempre me levaram, desde opera no Pedro II ou no Minaz, ou teatro infantil, eu sempre fui, no teatro, no cinema. Show acho que fui bem pouco. Eu sempre fui. [...] Ele mesmo fez teatro quando jovem, então eu sempre tive meio ligado ao teatro.

As entrevistas dos sujeitos pesquisados evidenciaram que, para aqueles que se encontram na fase da juventude, nem sempre a escolha por processos socializadores e educativos de natureza não escolar é fruto de uma "vontade intrínseca" e unilateral dos indivíduos, como foi constatado por Reymond (2003). Ainda que a escolha possa ser entendida como expressão do exercício de conquista de autonomia dos jovens, por tratar-se de uma "adesão voluntária", uma aposta, tal situação ocorre em meio a relações diversas, envolve posições e relações de poder, e visões de mundo, valores morais, éticos e estéticos, envolvendo, geralmente, membros da família de origem, de comunidades religiosas, professores da escola básica e mesmo integrantes do círculo de amizades. 
Em virtude dessas constatações que tendemos a concordar com Sposito (2008) e seu modo de compreender as relações entre educação escolar e não escolar:

na vida familiar, pais, de certo modo, negociam com seus filhos, por exemplo, as atividades extraescolares, uma vez que, em geral, não se considera como suficiente apenas a educação escolar, esta sim obrigatória. Apesar do desejo dos pais de propor novas modalidades de educação aprendizado de línguas, artes, esportes, entre outros - há sempre um espaço para a adesão do próprio sujeito, pois, sem um mínimo de concordância e aceitação, a proposta não se efetiva. (SPOSITO, 2008, p. 88, grifo nosso).

Desta maneira, trata-se agora de discorrer e analisar que contribuições o Curso de Iniciação Teatral ofereceu aos processos socializadores e de autonomia dos jovens que conosco dialogaram.

\subsection{Contribuições do fazer teatral aos processos de socialização e de autonomia dos jovens}

Antes de adentrarmos na descrição e análise das contribuições oferecidas pela proposta educativa à socialização e autonomia dos sujeitos da pesquisa, entendemos que seja importante recuperarmos a concepção de autonomia que mobilizamos neste estudo, tendo por as formulações, convergentes, registradas por Singly $(2004 ; 2005)$ e Danilo Martuccelli (2007).

Para os dois sociólogos a autonomia guarda relações com os processos identitários e a capacidade de formulação e expressão de um juízo crítico e próprio na relação com a alteridade. Assim, para Singly (2004; 2005), aquela condição pode ser entendida como um trabalho do indivíduo de forma a "outorgar a si mesmo uma lei própria e uma visão de mundo ou um 'mundo"” (SINGLY, 2004, p. 261; tradução livre).

Já para Martuccelli (2007), a autonomia como uma capacidade de "juízo crítico", supõem:

$\mathrm{Na}$ modernidade, a independência do indivíduo em sua vida privada, e a garantia política de seu livre exercício, ou seja, muito mais que uma autossuficiência quimérica do Eu. A noção de autonomia não contraria certamente as relações existentes entre o indivíduo e seu entorno, mas submete esse vínculo a um trabalho crítico. (MARTUCCELLI, 2007, p. 39; tradução livre).

A partir daquelas condições, o indivíduo autônomo pode ser entendido como aquele que é: 
capaz de dar-se uma lei própria, frequentemente a partir de elementos externos, que se convertem, não obstante, depois de um exame de consciência, a partir de regras pessoais. A autonomia não anula a dependência do indivíduo em relação ao mundo, mas modifica seu significado, posto que se transforma, de alguma maneira, em um vínculo aceito e reformulado pelo indivíduo mesmo. (MARTUCCELLI, 2007, p. 39; tradução livre).

Ao levarmos em consideração as noções dos autores acima, nos defrontamos com as entrevistas dos jovens e delas procuramos extrair indícios de possíveis contribuições do Curso de Iniciação Teatral aos seus processos de socialização e, sobretudo aos seus processos de autonomia. Assim, de seus depoimentos selecionamos as contribuições que, segundo eles, lhes permitiram um maior "conhecimento de si" ou "autoconhecimento", a força para se expressarem e tomarem "posições no espaço público", a coragem de assumir a "orientação sexual", o reconhecimento e aceitação de caráter "étnico-raciais" e, por fim, a aceitação do corpo na fase da juventude.

Em outros termos, entende-se que as contribuições mencionadas expressam conquista de autonomia dos indivíduos jovens e também o que denominou Augusto Boal "autoconhecimento" e "subjetivação" proporcionados pela atividade teatral, ou seja:

capacidade ou propriedade humana que permite que o sujeito se observe a si mesmo, em ação, em atividade. $\mathbf{O}$ autoconhecimento adquirido permitelhe ser sujeito (aquele que observa) de outro sujeito (aquele que age); permite-lhe imaginar variantes do seu agir, estudar alternativas. $O$ ser humano pode ver-se no ato de ver, de agir, de sentir, de pensar. Ele pode sentir-se sentindo, e se pensar pensando. (BOAL, 2002, p. 27, grifo nosso).

\subsubsection{O curso de formação teatral e o "conhecimento de si”"}

O “conhecimento de si” é uma dimensão da experiência dos indivíduos que não depende apenas de um movimento que apela a sua interioridade, ele ocorre na relação com a alteridade - seja essa individual ou coletiva, assim o autoconhecimento é produzido e apropriado pelo indivíduo em meio às interações e as relações sociais que ele estabelece com diferentes atores em variados espaços sociais e culturais, ou seja, o "conhecimento de si" sempre implica o trabalho do indivíduo a partir do que ele acumula, extrai e se apropria das relações sociais que estabelece no tempo.

Quando perguntado sobre as contribuições da formação teatral oferecida pelo IRC à sua vida cotidiana, Ivan (17) afirmou que não só ele percebe mudanças significativas em suas 
experiências do dia a dia, elas são também percebidas pelos professores da escola de ensino médio que frequenta. Segundo o jovem seus docentes reconhecem que sua entrada no curso de teatro teria influenciado de forma positiva tanto o seu desempenho escolar quanto o seu envolvimento e participação em outras instâncias do ambiente escolar, como o grêmio estudantil. Aquele processo educativo teria, inclusive, despertado capacidades ou habilidades que, provavelmente, continuariam latentes, tais como a disciplina, a responsabilidade, a relação com o conhecimento acadêmico e histórico, a participação social e política no ambiente escolar. Em suas palavras:

Meus professores percebem um avanço, eles que mais me passam isso, que às vezes eu não percebo. E uma questão de responsabilidade, principalmente. $\mathrm{Eu}$ era uma criancinha bem largada mesmo! 'Vou fazer lição de casa amanhã'. E hoje em dia, sou o exemplo da sala, inclusive sou presidente do grêmio, e levo projeto de leitura pra escola, projeto de leitura dentro da escola mesmo e a gente tem um grupo. É uma das contribuições que o teatro tem na minha vida. Responsabilidade. A questão de conhecimento, conhecimento da literatura do Brasil, ajudou bastante também, porque eles influenciam a gente a ler bastante também, textos de dramaturgia, também brasileira. Enfim, historicamente e moralmente, os princípios que arte me ajudou a construir.

Outra importância que aquele curso teve na vida cotidiana desse jovem guarda relações com o desenvolvimento do gosto pela literatura, pela leitura e pela cultura em sentido universal. Filho de pais que não adquiriram o hábito da leitura, ele sublinhou as mudanças por que vem passando:

P- Então, essas atividades que você faz agora, antes, você não imaginava fazer? Você acha que o teatro tem influência nisso?

R- Não, não imaginava. Sim, bastante influência. Uma coisa que eu percebo: meus pais, eles não lêem; eles não têm esse hábito, eles não têm habito de ter contato com leitura e cultura... E eu também não tenderia a ter se não fosse o teatro. Acredito eu.

Andrei (17) afirmou que o fazer teatral é uma oportunidade de crescimento pessoal que engloba valores que estão além do gosto pela arte. Além disso, relatou que as experiências socializadoras e educativas daquele processo formativo o auxiliaram a perceber características próprias e posturas que precisavam ser mudadas: "você aprende a respeitar o lado do próximo, a se alimentar com conteúdos que só a arte pode te dar. E você aprendendo dia a dia, a respeitar o próximo e se conhecer”.

Sobre sua conduta anterior ao engajamento no curso disse-nos que costumava ser extremamente crítico e "apontava o dedo para o que considerava defeito em qualquer pessoa"; criticava as maneiras de ser e pensar. Agora, ele percebe que "ser diferente é bom", pois 
aprende-se com o outro, "com o diferente". Ainda declarou que o teatro é algo que compõe sua identidade:

[o teatro] ajuda a ser quem eu sou. Eu acho que se um dia eu me afastar do teatro eu acho que não vou me sentir completo. Vai tá faltando alguma coisa. Acho que não tem como estar longe dessa coisa, de atuar, seja onde for...Eu tenho que tá atuando, descobrindo novas coisas.

Andrei atribuiu também ao fazer teatral o sentido de se abrir ao convívio social, com os outros, sem perder sua individualidade ou abrir mão de suas singularidades.

Tipo na sociedade, tipo você tem que ser assim, como todo acha que tem de ser. Tipo coisas mínimas. Que no dia a dia você enxerga os olhares das pessoas. Hoje eu sou muito mais maduro quanto a isso: eu não to nem aí mais! Tipo não tem que ter cabelo comprido. Ah! você não tem que fazer teatro, você tem que fazer, sei lá, medicina. Prestar o Enem senão você não vai viver! Você vai morrer porque você não prestou o Enem. Eu não acredito nisso. Porque a maioria vai prestar medicina... eu quero teatro, não tem porquê. Ou não do o teatro, posso envolver outras mídias no meio, mas quer viver em meio a isso. Ser ator. Eu não quero me sujeitar a fazer o que os outros querem. Porque muita gente perde sua vida entorno disso, é infeliz. E fica se questionando.

Posicionamento semelhante ao de Andrei podemos encontrar nas palavras de Natália(18), quando fala sobre como o curso do IRC impactou nasas relações e interações sociais que estabelece ali e nos outros espaços como a escola e o meio familiar:

Nossa, eu era muito auto-suficiente. Sempre eu que resolvo, sempre eu que faço, eu consigo sozinha e já era.Eu, eu e só eu. Ai chega aqui como é que faz... no começo mais de vinte pessoas. Meu Deus eu preciso aprender a conviver em grupo. (Risos). Eu sempre fui criada muito sozinha, eu no meu cantinho, mesmo tendo bastante amigos e tal, mas eu sempre fui eu no meu cantinho reservado. Nossa! me ajudou muito. A conviver com as pessoas, ter a paciência de entender que as pessoas são diferentes de mim(...)Eu fiquei mais, comecei prestar mais atenção nas coisas. E acho que fiquei mais liberta também, fiquei mais... liberta pra fazer as coisas, tipo eu preciso fazer eu não vou mais com vergonha das pessoas que estão em volta. Eu simplesmente vou e faço, as pessoas não tem nada a ver com a minha vida.

Já para Igor (18) o fazer teatral foi, entre outras coisas, uma forma de autoconhecimento, proporcionado pelas vivências, pelos jogos e situações que o fizeram "deparar-se consigo mesmo". Disse-nos que se percebia inconstante, mas que percebeu suas "falhas". Ao refletir sobre a efemeridade da vida pode dar mais valor a ela e ter mais "gana de viver".

O jovem declarou também que, ao realizar os exercícios propostos pelos educadores do IRC, aprendeu a controlar o medo de errar, conquista que, em seu ponto de vista, abrange a 
sua educação como um todo. Para exemplificar, discorreu sobre a assertividade adquirida e como ele vem se posicionando em outros espaços de convivência que integra, como o da igreja evangélica e o do "grupo ensino" (CÂNDIDO, 1964) do curso superior de artes visuais que frequentava:

R- Me ajudou numa questão bem específica:no medo de errar. Quando você entra no teatro eles falam: 'não tenha medo de errar'. E você sempre vem com esse medo. E o teatro me ajudou com isso, nas questões, nas provas, nas perguntas com os professores, nos debates, eu não tenho medo de errar, sabe?Eu pergunto mesmo e isso é legal

P- Antes de fazer teatro você perguntava menos é isso?

I- Não. Eu me tirava, não sei qual a palavra certa pra isso... eu me ausentava pras coisas, dos debates, porque eu tinha muito medo de errar. Então, tinha medo de falar alguma coisa e...'nossa vou falar merda'.

\subsubsection{Capacidades de expressar opinião e tomada de "posições no espaço público"}

Nádia (27) afirmou não ser uma pessoa tímida, mas que o teatro a tornou mais desenvolta no que concerne a emitir suas opiniões e também ouvir as opiniões dos outros, pois, segundo ela, "todos têm o direito de se expressar". Diz ter perdido o receio de se , e isso é refletido em outros lugares como no ambiente de trabalho:

Por exemplo, numa situação no meu trabalho... eu teria que falar com a minha gerente, e um corretor... alguma situação que eu falaria [..]com receio da minha gerente. Hoje não, eu não tenho mais! E vice-versa, que teria que falar pra ela e não falaria na frente do corretor ou do cliente por receio de um dos dois... então hoje eu não tenho mais. Então, isso me ajudou bastante.

Para Ivan a imersão no curso o levou a refletir sobre assuntos que não lhe incomodavam ou ao quais não dava atenção. Ao formular hipóteses sobre o mundo e a sociedade, teceu comentários sobre valores éticos e morais que incorporou pela mediação daquele processo educativo, e como ele vivencia os aprendizados nele obtidos nas trocas com seus pares, tanto no interior do IRC como fora dele:

Eu tenho uma experiência. Tem uns caras, tem um amigo meu, a gente tava andando, de repente a gente viu umas prostitutas na esquina e ele começou a zuar com as meninas, sabe? A xingar e blábláblá. Aí de repente, eu perguntei pra ele porquê da agressão às meninas. Daí, ele começou a falar que isso não e coisa que uma pessoa integra fazia, que tem muito serviço no mundo e blábláblá.... Começou a encher de lorotas. Daí, eu virei pra ele e falei: 'por mais que você tenha todas essas opiniões, eu as entendo[as prostitutas]. Eu as entendo porque... não que elas não tenham oportunidade, talvez elas tenham. Mas o contexto, a vivência, a vida que elas tiveram as influenciou a isso. Então, antes de você criar preconceito, é legal você ter um estudo de 
maneira geral,[...] mas estudo geral do que acontece, que leva uma pessoa a chegar naquela situação.

Segundo esse jovem, o envolvimento com o curso de teatro the proporcionou maior reflexividade, pois passou a questionar suas condutas e os valores éticos e morais que esposava, tem contribuído para que ele possa entender melhor o mundo e as pessoas:

É de extrema importância na construção de moral e ética [...]. Assim, não diretamente, mas indiretamente, o curso proporciona sabe, a questão de construção ética, moral e o convívio social; principalmente,o convívio social. Entre a gente, eles começam a quebrar tabus de preconceitos sociais fora do teatro [...]. Eu também tinha esses preconceitos; eles me ajudaram bastante em relação a isso.

Outro educando, Andrei (17), contou-nos que se achava "tímido" e "naturalmente reservado", mas, após o ingresso no curso do IRC disse que se tornou mais articulado, e que não tem mais medo de exigir, de lutar. Como exemplo, afirmou que vem se tornando mais preparado para o convívio social, para interagir e se comunicar com o outro como indivíduo e como ator; se antes, agir com "violência" fosse uma possibilidade, hoje age com mais "respeito" diante da alteridade, trata com igualdade os diferentes e suas diferenças:

Eu tenho certeza que eu vou levar tanto na questão social - como eu disse, respeito ao próximo, e como ator. [...]. Poder falar com as pessoas... Antes de entrar ali, eu não sei se eu conseguiria ter esse diálogo como eu estou tendo hoje [...] perante as pessoas; é no dia a dia, sabe? Se tiver algum problema talvez eu saiba resolver melhor entendeu? [...] talvez antes eu usaria a violência, hoje já não. Não espere eu bater em alguém porque isso não vai acontecer.

Sobre sua participação como cidadão na espacialidade onde mora, nas relações com o poder público, Andrei discorreu sobre situação que envolveu a defesa de seus direitos sociais e culturais, assim como os de seus pares: o curso de teatro que freqüentava deixou de contar com o apoio financeiro do Executivo Municipal. Ao tomar conhecimento do ocorrido, ele se mobilizou em defesa da causa e foi pessoalmente falar com o prefeito:

Aí, eu fiz um abaixo assinado (risos), e fui nas escolas estaduais pedir que assinassem. Coletei 350 assinaturas, se tratando da [cidade onde moro] foi muito (risos) [...] Eu queria fazer alguma coisa, não queria ficar parado vendo a panaquisse: "como assim, sem teatro? Pelo menos alguma coisa tem que ter naquela cidade que não tem nada [...]. Meu ex-diretor me ajudou, montou umas colunas de abaixo assinado, fui nas escolas com uma colega [...] Eu pedi licença e falava que [a cidade] tava passando por uma dificuldade em questão cultural, que a gente precisava de espaço, queria voltar pro teatro. [...] Agendei uma conversa com o prefeito e fui lá levar o abaixo assinado. Tirei uma cópia porque se eles sumissem com o abaixoassinado... Aí ele deu aquelas conversas de político de sempre, que o 
processo tava andando [...] Aí em março, era em fevereiro, soltou o panfleto que ia voltar [o curso] em abril!

\subsubsection{O fazer teatral, a autoaceitação da orientação sexual e o pertencimento étnico-racial.}

De acordo Alexander (19), a primeira contribuição do Curso de Iniciação do IRC, para a sua vida cotidiana, tem relação com o que chamou de "autoaceitação" e a aceitação do outro. Comentou o jovem que após a morte da mãe, começou a se fechar cada vez mais e não conseguia aproximar-se do seu pai. Ademais, disse-nos que continuamente enfrentava dificuldades em relação a outras dimensões de sua identidade: a gagueira ${ }^{39}$, sua orientação sexual e o fato de ser negro.

Büchel \& Sommer (2004, p. 160) entendem que as "vacilações" ou "interrupção da fluência acarretadas pela gagueira, podem provocar "emoções de natureza negativa, tais como medo, embaraço ou irritação", pois prejudica a capacidade de interação e comunicação verbal do indivíduo, trazendo-lhe implicações sociais e econômicas "devastadoras".

Em sua entrevista, Alexander assinalou as decorrências negativas da gagueira em sua vida pessoal e na dinâmica de suas interações e relações, mas também frisou a importância do processo educativo do IRC para enfrentar aquela "desordem" da linguagem e da comunicação:

Eu não aceitava eu mesmo, porque eu gaguejei toda minha vida. [...) Eu gaguejei e conforme eu fui crescendo, eu fui me fechando cada vez mais. Isso também foi um dos motivos para que eu entrasse no teatro.

Em sua entrevista, esse educando também discorreu sobre o sofrimento e os problemas de autoaceitação vivenciados por longo tempo em virtude de sua orientação sexual e a negritude ${ }^{40}$.

\footnotetext{
${ }^{39}$ De acordo com aqueles autores, gagueira ou disfemia, trata-se de "uma interrupção na fluência verbal caracterizada por repetições ou prolongamentos, audíveis ou não, de sons e sílabas". O termo não designa uma "doença", mas pode se referir, simultaneamente, a uma "desordem e um sintoma". Pode-se distinguir dois tipos de gagueira: a do "desenvolvimento persistente", que ocorre na fase da infância e a "adquirida" ou "neurogênica" que decorre de um "dano cerebral bem definido", ocasionada por "uma hemorragia intracerebral ou um traumatismo craniano". (BÜCHEL \& SOMMER, 2004, p. 159). Disponível em: http://www.gagueira.org.br/arquivos/causa_da_gagueira.pdf. Acessado em maio, 2016

${ }^{40}$ De acordo com Munanga : "É importante frisar que a negritude embora tenha sua origem na cor da pele negra, não é essencialmente de ordem biológica. De outro modo, a identidade negra não nasce do simples fato de tomar consciência da diferença de pigmentação entre brancos e negros ou negros e amarelos. A negritude ou a identidade negra se refere à história comum que o olhar do mundo ocidental "branco" reuniu sob o nome de negros. A negritude não se refere somente à cultura dos portadores da pele negra, que aliás, são todos culturalmente diferentes. Na realidade, o que esses grupos humanos têm fundamentalmente em comum não é, como parece indicar o termo negritude, a cor da pele, mas sim o fato de terem sido na história vítimas das piores tentativas de desumanização e terem sido suas culturas não apenas objeto de políticas sistemáticas de destruição, mais do que isso, ter sido simplesmente negada a existência dessas culturas.” (MUNANGA, 2012)
} 
As experiências narradas por esse jovem têm vínculos diretos com os temas do corpo, dos processos de identitização e de individuação, e também são experimentas por sujeitos que se encontram em diferentes idades do curso da vida, mas em especial aqueles os que se encontram na fase da juventude, sobretudo porque se percebem imersos em uma sociedade que, no espaço privado como na vida pública, valoriza e naturaliza a representação do "indivíduo soberano" da modernidade, isto é, "homem, branco, adulto, heterossexual, são de espírito e trabalhador" (MARTUCCELLI, 2007, p. 91).

Alexander, ao se dar conta de que em relação aos aspectos raciais e de sua orientação sexual, se distancia daquela representação normativa experimentou problemas de "vergonha" e de autoaceitação, sobretudo diante do "olhar externo", que interfere diretamente em seu processo identitário.

Fabbrini \& Mellucci (1992), sem suas reflexões sobre a juventude, assinalam o peso da "timidez, da vergonha, e do segredo" de muitos jovens em relação a seus corpos. Para os pesquisadores, a vida juvenil é também a idade do "segredo" e, portanto, pode-se

compreender o significado do enrubescer, do senso de vergonha, de pudor e de timidez que caracteriza tão frequentemente o adolescente nas relações. $\mathrm{O}$ olhar externo, ao qual é assinalado um tão grande poder de definir a identidade, pode ser vivido como opinião definida sobre a própria pessoa. Pela fragilidade do limite que separa o mundo interior daquele exterior, o adolescente percebe o risco que o olhar do outro tenha a capacidade de penetrar seu mundo convulsionado, de perceber-lhe a confusão e a periculosidade. Teme ser visto como é verdadeiramente e, em particular, corre o risco que seja descoberto pelo adulto tudo o que se relaciona com as novas competências e sensações do corpo sexuado (...) (FABBRINI \& MELUCCI, 1992, p. 54, tradução livre)

$\mathrm{Na}$ fala de Alexander (19), o círculo social da Igreja que frequentava e alguns de seus "ministérios" tiveram importância fundamental em suas relações sociais e sua rede de sociabilidade - convivência e amizade com os pares. Naquele território, ele estabeleceu laços de amizade, se envolveu com práticas culturais na área da dança, vivenciou as primeiras práticas formativas na área do teatro, e relacionou-se afetiva e sexualmente com tanto com menina como com menino. Porém, diante das experiências de namoro que experimentou, deuse conta que no círculo religioso evangélico sua homoafetividade não seria aceita, situação que causava temor, angústia e "vergonha".

No intuito de ser aceito e respeitado pelo grupo de amigos, namorou com uma menina, porém, revelou que sentia como se estivesse mentindo. Ao expor essas experiências, ele 
mostrou-se um pouco constrangido com esses temas, contudo, conforme for discorrendo sobre eles, foi se soltando e assinalou as decisões que tomou, de modo a sentir menos heterônomo:

É por que a questão, tipo assim, que eu namorava... Eu namorei uma menina durante três anos, e até então... como você vai na Igreja tem aquela história né? Por você ser gay, você tá errado, isso é um pecado! Até então eu comecei a namorar... Assim, eu gostava dela com certeza, não tenho que reclamar dela, uma menina super exemplo, responsável pra caramba. Mas eu comecei a namorar por questão de não aceitação de mim, de mim mesmo. [...] Aí comecei a namorar com ela, a gente namorou três anos assim... Eu não falo que o quê vivi com ela foi mentira, porque foi uma coisa super verdadeira, não chegou a acontecer... nada. Mas aí eu entrei no teatro e comecei a ver coisas, vi que não tinha nada a ver, que eu não tinha que ficar mentindo pra mim mesmo, pra poder impressionar a Igreja, pra poder impressionar Deus, entre aspas, porque Deus tem é que me aceitar da forma que eu sou.

Até então, eles vinham..., até então, eles me reprimiam... Não que eu saia falando e tal. Quando eles descobriram, foi porque eu traí minha namorada com... um garoto. Até então ninguém tava sabendo. Aí eu comecei a me remoer, aquilo dentro de mim, fui e contei pra ela. Só que o menino com quem eu fiquei, também era da Igreja. Ai, ele contou pra um monte de gente. (ri) Todo mundo ficou sabendo... Então, ela foi lá e terminou comigo.

Até então, eu ia continuar na Igreja, mas eu pensei: 'vou continuar na Igreja, vivendo uma mentira! Não que eu viva uma mentira, mas a Igreja não me aceita! Vou ficar lá, por quê? Toda vez que eu tiver lá, vão e falam. Ai, quando estourou a bomba o Alexander virou o "o viado da igreja". Ficou aquela história e eu preferi sair.

As decisões tomadas por Alexander tiveram consequências diretas para o plano da sua sociabilidade: ele perdeu os laços de amizade que mantinha com os pares do círculo religioso. As novas amizades, agora são do teatro, afirmou o jovem. Nesse caso, o espaço-tempo do IRC e o seu curso de teatro mostraram-se ambientes mais propícios e acolhedores à assunção de dimensões de sua identidade, que, segundo ele, eram reprimidas nos círculos de sociabilidade e de socialização da Igreja neo-evangélica:

P- E esse processo que você contou, desse conflito. Foi concomitante com o Ribeirão em Cena, foi ao mesmo tempo?

R- Foi.

P- Então você foi tomando a decisão enquanto você estava no Ribeirão em Cena, e resolveu sair da igreja?

R- Foi, acho que se eu não estivesse no Ribeirão em Cena acho que eu ainda estaria na Igreja, ainda estaria namorando, ainda estaria... lá. E eu prefiro assim: que eu tenha saído, que eu tenha me descoberto, entre aspas. 
A partir destes elementos da entrevista de Alexander tem-se que o teatro e o curso de fazer teatral do IRC assumiram importância significativa em sua vivência juvenil e em seus processos de construção da identidade, pois por intermédio daquele processo educativo ele fortaleceu seu coming $\mathrm{out}^{41}$, assumindo a orientação homoafetiva - e vem aceitando com menor constrangimento - "vergonha" - e o fato de "negro".

Ah, e tem aquela 'história' de que você é... gay, e tal, sei lá... Isso também (o teatro) ajudou a aceitar. É isso. Aceitação também de... eu não gostava de ser negro, eu achava que ser negro era uma coisa totalmente... ah que ninguém gosta dos negros e tal, hoje eu também me aceito mais, com isso.

Dois outros entrevistados, Igor (18) e Lucas (17), também falaram de experiências que tinham a orientação sexual como tema relevante e o como o curso do IRC os auxiliaram a conviver com ela de modo menos tenso.

Igor disse-nos que a vivência de sua orientação sexual estava em curso e revelou que enfrentava conflitos com os valores morais de integrantes de dois círculos sociais que integrava - a família e uma igreja evangélica. Falou-nos que quando interrogado sobre sua sexualidade assumia a "reserva" ou o "segredo", para afirmar "eu não sei te responder". Sorrindo, o jovem atribuiu a si ter uma "energia feminina", definindo-se como "um cara grande e gordo, com uma voz fina [...] meio soltinho, afeminado", situação que o levava continuamente a satisfazer a curiosidade dos outros sobre sua orientação sexual. Para ele, o tema da orientação sexual dos indivíduos - jovens ou adultos - é encarado com mais naturalidade no círculo daqueles que se envolvem com o teatro, e percebia também que ambiente religioso em que transitava não estava preparado para entender o amor em suas diferentes formas.

Diante de situações por vezes constrangedoras Igor contou-nos que criava códigos específicos de comportamento para transitar pelos círculos sociais que frequentava. Assim, ao ser solicitado pelos colegas da Igreja a realizar atividades teatrais ou conduzir oficinas, ele adaptava os exercícios para que os participantes tocassem o menos possível determinadas regiões do corpo de maneira que não tivessem pudores e relutassem em realizar as atividades. Em suas palavras:

Sim, na igreja você só pode colocar Jesus e o diabinho e Jesus vencendo o diabo. Eu não sentia na igreja espaço pra colocar os questionamentos humanos, a doutrina 'ah eu não posso colocar essa tal coisa... 'mas porque não pode fazer tal coisa?' Então a gente vai investiga essas imposições sabe?

\footnotetext{
${ }^{41}$ Coming out ou Coming out of the closet, categorias nativas do universo LGBT que pode ser traduzida livremente como saindo do armário, trata-se de anúncio público da orientação sexual ou identidade de gênero de alguém ou de si mesmo.
} 
Com o teatro isso é possível, isso é massa!A pessoa vai crescendo como pessoa e amadurecendo a cabeça. Vai abrindo outros horizontes... não que vá contra, nem ferir sua santidade ou fé cristã, mas é algo que vai te fazer refletir e ver o que aquilo não tem nada a ver, que é humano. Além de tudo eu percebo que quando a pessoa começa a fazer teatro na igreja- hoje eu tenho a oportunidade de estar à frente no teatro lá na Igreja- percebo que eles vêm cheios de pudores, que é de certa forma medo: 'mas eu posso fazer isso? Como funciona essa questão de energia?'. E eles pensam que é uma coisa de nova era...(risos). Mas você vê uma evolução neles. Você nota que as pessoas começam a se abrir muito mais. É legal porque sei lá,: tá o grupo do teatro da igreja aqui ,e ali está o ministério de sei lá, de canto... você percebe que os papos são muito diferentes.

Lucas (17), por sua vez, vivenciou o teatro em várias situações em sua infância, pois na maioria das escolas privadas nas quais estudou tiveram atividades teatrais. Também foi levado pelos pais ao teatro com frequência desde a infância. O jovem é enfático ao ressaltar que o teatro o auxilia a compreender a realidade, e foi essencial para incentivá-lo a buscar aprender sobre as coisas e o autoconhecimento, pois o fez desejar saber mais.

Segundo esse jovem, seus pais revelaram ter preocupações sobre a violência que atinge as pessoas que contrariam condutas afetivas heteronormativos, ele inclusive, pois se definiu como "pansexual", na medida em que "fica" com o outro independentemente de seu pertencimento sexual ou de gênero, ou da binária homem-mulher. Ao afirmar não se identificar como "gay", lembrou-nos de um debate que teve com um membro de sua família:

Eu cheguei a debater com a minha vó isso. Ela não sabe que eu também fico com meninos. Mas ela tava falando... meu primo namora faz dois anos, ela só descobriu agora [...] ele namora meninos. Eu não sou gay, eu sou pansexual, é uma coisa minha, eu não prefiro ficar com homens, ou prefiro ficar com mulheres: eu prefiro ficar com pessoas. E uma coisa minha. Daí ela tava falando que isso é absurdo, que ela não aceita, e eu defendendo e vendo que ela, uma pessoa estudada, que foi professora, e que mesmo assim tem preconceito. É a sociedade que impõe, entendeu? Minha irmã também, ela namora uma menina [...]. Minha mãe no começo teve muita dificuldade, mas eu pelo menos acabei percebendo que não era preconceito dela, era tinha medo do que a sociedade ia fazer entendeu? Eu já vi, por exemplo, a irmã, não sendo expulsa, vai, mas o segurança pediu para elas se afastarem, lá no shopping.

Para Lucas, o ambiente teatral é um espaço onde encontrou pessoas mais abertas a compreender a diversidade das experiências humanas, trata-se de lugar de debate e de respeito de todas as "políticas" da sexualidade:

um lugar de respeitar todas as políticas, assim como respeitar todas as religiões, mas acho que um lugar pra pensar, e como lugar pra pensar devese discutir, deve-se debater. Deve debater política, deve debater sexualidade, deve debater feminismo (...). Deve debater tudo. Porque eu acho que o teatro é o melhor jeito de você conseguir pensar um mundo melhor, [ele] dá essa possibilidade. 
As experiências de Lucas, Igor e Alexander permitem apreender a multiplicidade de instâncias socializadoras em que os jovens se envolveram - antes e simultaneamente o envolvimento com o curso de iniciação teatral; elas também auxiliam na compreensão dos caminhos que percorrem de modo a forjarem uma visão de mundo própria, seja ela concordante ou não com as visões de mundo dominantes dos adultos e das instituições em que eles estabelecem relações de pertencimento.

Nas falas dos três foi possível situar os apoios que o fazer teatral e as interações que elas travam no interior do IRC trouxeram aos seus percursos para aceitação de uma orientação sexual diversa daquela considerada como normativa pela modernidade - a heterossexual. No caso específico de Alexander, ele não deixou de fazer referências ao apoio encontrado no curso de teatral para se aceitar como "negro" e sentir menos vulnerável, diante do "olhar externo" (FABBRINI \& MELUCCI, 1992).

Enquanto a narrativa de Igor, não nos permite afirmar que ele tenha explicitado uma autoaceitação quanto a uma orientação sexual diversa da heteronormativa, pois a "reserva" vinha sendo usada como estratégia diante de indagações do outro, do "olhar externo", ao mesmo tempo, ele explicitou que não que teve temor em assumir um trabalho artísticocultural que envolve o corpo, as emoções, os sentimentos, a representação, no cenário da Igreja evangélica que frequentava, transferindo para seus pares um conjunto saberes e uma visão de mundo e cultura que vem formulando a partir de sua imersão no curso do IRC. Ao discorrer sobre tais movimentos ele nos deu fortes indícios de que como vinha encaminhado seus processos identitários, também os de autonomia e individuação.

Já nos casos de Alexander e Lucas, ambos explicitaram o apoio que encontram nas atividades do fazer teatral e do teatro para firmarem posições identitárias e de autonomia, quanto às respectivas de orientação sexual e afetiva, e Alexander também fez referências explicitadas em relação a autoaceitação relativa à sua negritude. $\mathrm{Na}$ fala de ambos foram mencionados os esforços que empreendem para se posicionarem no espaço privado e público com visões de mundo própria, mesmo que muitas, eles enfrentem temores, tensões e conflitos com as visões de mundo partilhadas por membros das gerações adultas de círculos sociais em que estabelecimento pertencimento: a família, a Igreja, a escola, o grupo de amizades, entre outros. 


\subsubsection{O corpo dos jovens, angústias, a busca de identidade e contribuições do fazer teatral}

No capítulo I, tratou-se da importância que tem corpo do indivíduo para o fazer teatral e o teatro, pois sendo "o ator é seu próprio corpo", os indivíduos que se envolvem com o fazer teatral e o teatro devem compreender e aprender a considerar o corpo como uma unidade, uma totalidade, e não como uma "entidade apartada de si, suprimida e castrada em suas emoções e pensamentos (AZEVEDO, 1990, p. 138).

Todavia, a pesquisa desenvolvida dialogou com adolescentes e jovens que se encontravam em processo de formação inicial do fazer teatral, ainda não gozavam do estatuto de atores. Nas entrevistas que realizamos, muitos deles revelaram a importância que aquele processo educativo teve para que entrassem em contato com novos olhares em relação à compreensão do corpo e aos sentidos que eles atribuíam a esse domínio da experiência individual e social.

Antes de nos determos nos aprendizados extraídos por alguns jovens sobre o tema acima, convém recuperar as contribuições de Fabbrini \& Melucci (1992) sobre as possíveis relações e sentidos que os indivíduos que se encontram na fase juvenil estabelecem com corpo. Para os pesquisadores, para muitos jovens

O corpo não é um objeto em relação a um sujeito que olha, o observa analiticamente e integra assim elementos cognoscitivos novos. Os fatos do corpo compõem uma unidade com o olhar de que os observa e as transformações fisiológicas que são orientadas pelo sentido e pela carga afetiva que são a eles atribuídos. Para compreender o adolescente em seu modo de ser-no-mundo é preciso partir de um corpo não como 'coisa' possuída, mas como campo de experiência que coincide com a presença mesma do sujeito (FABBRINI \& MELUCCI, p. 45, tradução livre).

Observam ainda os autores, que

o corpo que o jovem ou jovem veem agir, aquilo que expõe ou escondem do olhar, aquilo que percebe através das sensações agradáveis ou dolorosas da mudança fisiológica não é uma coisa, mais sua própria pessoa. [...] o ser-no-mundo como presença sintetiza assim o ser biológico, a experiência pessoal, a capacidade de relação e de contato, o fluxo vivido de pensamentos, sentimentos e emoções e consciência integrada de tudo isso.

As falas de alguns sujeitos que contribuíram com a pesquisa, e que fizeram referências ao tema do corpo, se aproximam das reflexões de Fabbrini \& Melucci (1992), nos depoimentos que nos deram eles também explicitaram às contribuições oferecidas pelo curso do IRC para que eles percebessem o corpo como "um campo de experiência", uma via para construção de seus processos de identização e um modo de "ser-no-mundo", casos por exemplo de Nádia (27), Ivan (17), Olga (20) e Nicolas (17). 
Nádia falou de forma resumida sobre as contribuições do fazer teatral para sua socialização e educação. Em sua opinião, os exercícios e as práticas desenvolvidas na sala de ensaio do IRC não têm relações diretas com o seu cotidiano, porém ela não deixou de arrolar um conjunto de contribuições que, em sua avaliação, o curso vinha lhe acrescentando, tais como: a oportunidade de conhecer e conviver com pessoas mais abertas do ponto de vista dos valores morais, mais respeito quanto à religião, à liberdade de se expressar, ao trabalho, à sexualidade e, também, e a perda de reservas em relação ao corpo., ainda, que no ambiente da formação teatral pode encontrar e conviver com os diferentes e as diferenças, o que fortaleceu o respeito à alteridade ao outro.

Também em relação.... [...] ao pudor em relação ao corpo. Que isso eu já não tinha muito, agora eu já não tenho nenhum! Corpo é carne, todo mundo tem... é tudo igual! E não tem esse negócio, de... (gesto de recusa do toque) (risos), não tem mais esse negócio de pudor. Que é uma coisa simples! Coisa que a gente vê com muita malícia, que não tem motivo pra ver com malícia.

Para Ivan as apropriações que fazia do fazer teatral tinham vínculos com o que ele chamou de "bem-estar" relacionado à saúde, ao conhecimento, ao "controle físico" e consciência de seu corpo e de seu bem-estar:

Vamos lá: controle físico, eu tenho alguns probleminhas físicos. Então, um que me ajudou bastante foi na questão do controle físico, e no conhecimento corporal. Porque eu tenho uns problemas nos membros, então, de vez em quando, eles geram algumas dores e o Ribeirão em Cena tem muito essa questão do trabalho corporal, investem bastante nisso. E foi uma forma que eu achei também de me conscientizar de algumas coisas que eu fazia errado fisicamente. [...] É mais voltado pro teatro, mas você tira coisas pra sua saúde e pro seu bem-estar.

No balanço que fez sobre os benefícios que o fazer teatral vinha lhe oferecendo, Olga (20) fez questão de frisar que um deles foi o de aprender a prestar mais atenção em si e ao outro, em sua humanidade. Também para ela, o curso a fez valorar positivamente sua autoimagem, pois lembrou que várias vezes foi vítima de "bullying por ser gordinha"; tal ato de violência e preconceito lhe gerava bloqueios no estabelecimento de laços de amizades e nas "relações com garotos". No curso, teve oportunidade de refletir ativamente sobre essas questões, e contou-nos que ao desenvolver exercícios práticos envolvendo a figura do "palhaço" pode rir de si e minimizar a angústia que sentia em relação a seu corpo: "a gente acaba rindo daquilo que não gosta na gente, o bizarro, trabalha isso e vai se aceitando como é”. 
Os exercícios citados a ajudaram a perceber que possui qualidades que não são redutíveis às marcas externas de seu corpo, que o corpo "alimenta nossa busca de identidade" (MELUCCI, 2004, p.93),e tal constatação a tornou mais crítica quanto aos padrões de beleza corporal predominantes na sociedade contemporânea, "a onda do corpo com um fenômeno de mercado" (MELUCCI, 2004, p.93). Ao recordar das novelas da TV, como obras de ficção, Olga argumentou: "as personagens principais são sempre muito bonitas, tem um corpo legal, cabelo lindo". Ao imergir nas atividades teatrais do IRC percebeu que os critérios valorizados na distribuição de papéis tendo em visa a montagem de uma peça não se guiavam, necessariamente, pelas representações de corpo e beleza apreciadas pelo mercado, ela entendeu que no contexto do teatro as escolhas são definidas pelo trabalho do ator e tem como premissa incentivar o crescimento das pessoas:

Ah.... porque o personagem combinou com você? Não! Lá você lê um texto e dali tiram dos seus movimentos, não pela sua beleza, pelo seu trabalho, pelo seu esforço. Pelo jeito que você é. Quando eu fiz a [personagem por ela representado], eu fiz não pela minha beleza, foi [escolhida] porque ia trazer o que me soltou mais, o que é um bloqueio meu.

A experiência de vivenciar uma personagem que entre outras características é agressiva e sensual fez com que a jovem pudesse refletir mais ainda sobre seu corpo, sua forma de lidar com os afetos e valorizar sua autoimagem:

me deu oportunidade de aceitar muita coisa, toda mulher quer sentir-se desejada, quer mostrar suas sensualidade, mas a gente tem vergonha por não se aceitar, eu tive que mostrar minha parte mais mulher, minha parte mais sensual.

Nicolas (17) demonstrou ter um grande apreço pelo IRC e declarou que o seu envolvimento com as práticas formativas do fazer teatral tiveram grande influência na sua vida, em seu processo de socialização, nas esferas afetivas e emocionais. Esse jovem definiuse como alguém fechado ao extremo, recordou que sempre teve muitos problemas para se relacionar com as pessoas, e que isso o teria o afligido muito principalmente durante o período da escolarização. Ele também nos disse que se sentia mal com sua aparência e sua vivência estudantil foi apática, não se aplicava, nunca foi reprovado, porém não via muito sentido na escola, evitava ao máximo se comunicar com os outros e preferia às vezes fingir estar dormindo para evitar o contato com o outro.

A entrevista com esse Nicolas foi uma das mais difíceis, devido ao seu caráter emotivo, foi interrompida por duas vezes quando o jovem se emocionava quando falava de si ou discorria sobre suas experiências juvenis: 
Eu não me aceitava... Eu acho que eu não me encaixava na sociedade, pode ser coisa da minha cabeça, mas. Eu que me fechava sabe? Sei lá, meio perdido em tudo, tudo que eu começava eu não terminava na minha vida. Eu nunca fui um aluno que deu trabalho, mas também nunca fui estudioso. Eu não gostava de estudar, sei lá eu ia pra escola... e como fala... eu não conseguia prestar atenção em nada, eu ficava pensando em mim, eu ficava muito dentro de mim... sabe, até hoje eu fico comigo dentro de mim, não consigo soltar... difícil cara... eu entrei no teatro pra tentar arrumar isso e de uma certa forma ajudou bastante, sabe?

Segundo o educando, o fechamento em si mesmo, a recusa de interagir com os pares da idade e o seu silêncio tinham relações com sua voz e sobretudo com sua aparência física "era muito gordo", o que durante muito tempo o incomodou.

De acordo com Fabbrini \& Melucci (1992)

Os problemas estéticos têm particular importância nesta idade e se estendem a todo corpo: parecem transpor as próprias fronteiras físicas para atacar muitos aspectos da realidade psicológica e social dos jovens. Em alguns casos, quando a imagem de si enche de dados negativos reais ou imaginários, a recusa do corpo chega a exercer fortes condicionamentos e autolimitações de tipo funcional: rapazes que não saem nunca de casa, moças que não comem nunca ou que, inversamente, comem sempre (FABBRINI \& MELUCCI,1992, p. 54)

Ao conhecer os novos pares no IRC, Nicolas se deu conta de que poderia conversar com as pessoas sem ser rejeitado:

não é só a gente que tem problemas, você vai conversando. Assim que é a vida... um ajuda o outro, às vezes rola uma conversa que da um $u p$ !.

Não, tipo.... eu era muito gordo, sabe... muito gordo, era muito gordo.... Não me aceitava por isso também, tipo talvez pela minha aparência, minha voz. Influenciava no meio que eu vivia. (embarga a voz, se emociona pergunto de quer que eu pause ele afirma, ficamos em silêncio. Dois minutos sinaliza pra retomar).

No IRC isso melhorou pelo convívio, se sente bem entre os colegas, fez amizades e percebeu que poderia ser aceito pelas pessoas:

me conheci mais. Eu descobri que consigo chegar no pessoal, falar com o pessoal [...]. O teatro me ajudou a meter a cara, ter mais coragem das coisas.

Os excertos das narrativas desses três jovens educandos, abordando as contribuições oferecidas pelo curso em teatro para que pudessem se aproximar de seus respectivos corpos, a melhor conhecê-los, a compreendê-los, e entender que o corpo é uma mediação para o autoconhecimento e o conhecimento do outro, podem ser interpretados a partir das observações de Melucci (2001) quando sobre o corpo e as relações humanas afirmou que aquele é, simultaneamente, 
símbolo e instrumento de comunicação, (...) é o canal de nossa afetividade. A relação entre os seres humanos não é feita somente de sentimentos e de ideias, mas é um encontro entre corpos. Essa consciência sempre foi muito profunda nas culturas tradicionais, nas quais o corpo desempenha um papel fundamental, não apenas nas relações entre os sexos, mas em todas as circunstâncias da vida social. (MELUCCI, 2001. p. 92)

\subsection{Jovens, o fazer teatral e seus planos futuros de trabalho}

Tal como realizado por Villar e Villar (2007) em sua pesquisa sobre as experiências de educação não escolar teatro e artes circenses de jovens do Grande $\mathrm{ABC}$ paulista e as relações deles com a esfera do trabalho do mundo artístico, também formulei questões aos educandos que participaram de meu estudo sobre os planos de futuro que eles elaboravam, visando uma inserção profissional na área do teatro ou das artes cênicas em geral, tendo em vista o processo de educação de fazer teatral em que estavam engajados.

Além de tomarmos como referência os procedimentos metodológicos e os resultados da investigação de Villar e Villar (2007), outras reflexões acadêmicas sobre os significados da juventude e dos jovens na atualidade nos orientaram nesse encaminhamento, em especial as reflexões elaboradas por Fabbrini \& Melucci (1992) sobre as características marcantes daquela "estação" do curso da vida, pois, segundo os autores, ela não é só transição e a mudança constante, nela também "estão concentradas [....] as articulações mais significativas da experiência humana", aquelas mesmo que encontramos diluídas no tempo da vida: o drama da escolha, a necessidade de mudar e o medo de fazê-lo".

Ainda sobre a juventude, insistem aqueles pesquisadores que os problemas que nela emergem pela primeira vez:

escolhas, dilemas, relação com mudanças contínuas, não são superados na adolescência, mas iniciam a partir dela a fazer parte do panorama existencial de cada um. São tensões atuais para cada adulto às voltas com a vida. Mas que etapa ou fase a superar, a adolescência configura-se como a passagem do limiar, além do qual se entreveem as cores da em toda a ampla gama de tons e de nuances: prazer, dor, aproximação e distância, incerteza e determinação, insegurança e certezas. [...] A manutenção da identidade, a responsabilidade, a capacidade de trabalho produtivo e de relações duradouras, longe de ser metas da maturidade, adquiridas de uma vez por todas com o esgotar-se da adolescência, representam pela duração da vida o resultado de um contínuo movimento de construção e de desconstrução da identidade pessoal. (FABBRINNI \& MELUCCI,1992, p. 10)

Mesmo tendo em conta as orientações mais gerais sobre as principais características da idade da juventude de autoria de Fabbrini \& Melucci (1992), para melhor avaliar e interpretar as respostas que os educandos entrevistados deram a nossa questão sobre seus planos futuros 
para a dimensão profissional, levou-se ainda em consideração que os doze (12) sujeitos pesquisados viviam juventude sob condições, processos e percursos diferenciados ${ }^{42}$.

Assim, no momento das entrevistas, alguns eles encontravam-se na "soleira" da idade juvenil (MELUCCI, 1997), estavam nos anos finais do ensino médio ou tinham acabado de concluí-lo e não contavam com experiências no universo do trabalho ${ }^{43}$; outros jovens, ainda vinculados à educação básica ou já integrados à educação superior, tinham experimentado a combinação dos ritmos da escolarização e do trabalho - formal e informal, desde a adolescência $^{44}$; duas jovens - Nádia (27) e Marina $(29)^{45}$, do ponto de vista etário estavam próximas à idade adulta, tinham concluído o ensino superior e possuíam acúmulo de experiências profissionais na esfera do trabalho formal.

Dessa forma, entre aqueles educandos que encontravam no período inaugural da vida juvenil ou não, mas não tinham construído experiências na esfera do trabalho, dois tipos de planos profissionais se destacaram: um deles foi aquele que associa a ocupação na área do teatro com ocupações em áreas distintas das artes cênicas, tendo em vista as incertezas financeiras que marcam aqueles que trabalham em teatro ou com o teatro; o outro tipo de plano foi aquele contempla tanto a formação superior como a atuação ocupacional exclusivamente na área do teatro, tendo em vista os aprendizados obtidos no curso de teatro do IRC.

Andrei (17), por exemplo, declarou que não deseja atuar de forma profissional só por "dinheiro" e que sua aspiração é a de se tornar ator e associar a tal prática outra ocupação em áreas diversas das artes cênicas:

eu pretendo envolver os dois porque infelizmente tem essa coisa de dinheiro que nos perturba né? Eu não quero ser do tipo de pessoa que vai fazer as coisas por dinheiro. Por isso não quero largar nem um nem outro.

Duas outras jovens educandas, Sofia (21) e Vânia (18), tem projetos de futuro relativamente semelhantes aos de Andrei. A primeira, planeja concluir a formação superior na

\footnotetext{
${ }^{42}$ Weisheimer (2013) contribui para entendermos as diferenças ente as noções de condição juvenil e situação juvenil, explicando que "a condição juvenil corresponde ao modo como a sociedade constitui e atribui significados às juventudes em determinadas estruturas sociais, históricas e culturais, implicado um modo de ser jovem determinado por estruturas sociais mais amplas. Desta maneira, busca-se destacar que,mais do que uma faixa etária, a condição juvenil é uma posição na hierarquia social. No caso dos jovens, corresponde a uma posição subordinada aos adultos. Lembrando que esta é, por definição, uma condição transitória que se perde com a passagem dos anos, os pesquisadores da UNESCO como WAISELFISZ (2004) argumentam que a superação da subordinação e a conquista de autonomia constituem o eixo central da trajetória que os jovens deverão percorrer. [...] Por sua vez, "a situação juvenil" diz respeito aos diversos percursos experimentados pela condição juvenil, ou seja, traduz as suas diversas configurações. Esta [...] categoria é utilizada então para referirse aos variados processos empíricos, condições conjunturais e particularizadas das múltiplas juventudes".

${ }^{43}$ Casos de Andrei (17 anos), Lucas (17), Vânia (18) e Sofia (21 anos).

${ }^{44}$ Casos de Ivan (17 anos), Nicolas, (17), Igor (18), Natália (18) Alexander (19 anos).

${ }^{45}$ Entre os doze (12) educandos, só Marina estava casada.
} 
área da Psicologia e, posteriormente, atuar profissionalmente como psicóloga e atriz, e tomou como referencias alguns de seus pares do IRC para tal previsão, com os seguintes argumentos:

Meu plano de vida é terminar o curso de psicologia, escolher a área que eu tenho que fazer, porque são muitas áreas. [...] Eu penso aquela coisa: de dia sou psicóloga, de noite sou atriz! Tem gente lá no curso que é assim. O próprio X [educando] ele é zootecnista, ganha grana dele lá, do jeito dele com os negócios dele lá, e é ator a noite! [...] São duas profissões, ele tem dois empregos. Totalmente diferentes um do outro.[...] Eu me vejo fazendo isso!

Vânia, ao retomar os aprendizados obtidos no curso de teatro, e realizando uma crítica ao lugar das artes e do teatro no contexto da educação escolar, descreveu um plano de atuação profissional que combinaria atividades no âmbito do magistério da educação infantil e a atuação de atriz. Em suas palavras:

Ao mesmo tempo eu tenho lido muito e [...]eu prefiro [...]fazer agora Pedagogia. [...] $\mathrm{Eu}$ acho interessante essa coisa de trabalhar com criança, mas eu não descarto a possibilidade de trabalhar com teatro e com criança. Eu tenho lido muito Viola [Spolin], e acho que jogos teatrais é uma coisa bem bacana, [...] tanto pra mim quanto pra criança, pra todos; mas pra criança principalmente, porque tá na fase de formação e tem escola que é muito "gaiola" [...] que prende a criança, e criança é pássaro. Tem que conduzir o vôo e não prender. Eu acho que o teatro permite isso, pelo que eu vi e aprendi eu senti muito essa vontade.

Meu plano é esse: fazer pedagogia agora, em questão de uma pesquisa pessoal, pra transferir o que eu sei pra criança ter oportunidade de aprender o que eu aprendi.

Desse conjunto de educandos - que não tiveram experiências no mundo trabalho, somente Lucas explicitou que aspira trabalhar exclusivamente na área do teatro, uma das razões que o levou a ingressar no curso de artes cênicas em universidade pública. Ao se referir ao curso do IRC, comentou os fundamentos de seu plano:

Foi no IRC que eu descobri que é possível fazer teatro. Que essa vida existe. Que não é só hobby, porque eu achava que para fazer teatro você tinha que ir pra TV ou passar no Big Brother. (risos). Quando criança eu pensava isso! [...] O IRC me ajudou, e nisso eu vejo minha vida totalmente diferente. Comecei a fazer agora, lá na [Universidade Pública], arte teatro licenciatura. Mas eu sempre tive vontade de fazer teatro porque eu gosto de poder me expressar de mandar uma mensagem. [...] Eu acho que é uma profissão que vai me levar muita coisa, porque a gente precisa de teatro precisa de cultura, de verdade!

Mesmo entendendo que pode vir a experimentar incertezas financeiras como profissional do teatro, ele as atenuou, afirmando:

Como tudo no começo, $[\ldots]$ num vou ganhar tanto quanto um médico, até porque eu não quero fazer TV, pelo menos agora. [...] Não me interessa agora fazer TV, mas no futuro pode ser. Eu acho que é uma vida mais difícil sim, mas é porque ninguém dá valor.

Entre os participantes da pesquisa que estavam no ensino ou tinham se integrado ao ensino superior, e combinaram escolarização e trabalho desde o período da adolescência, 
alguns jovens também discorreram sobre planos futuros associando a ocupação de ator com outras em áreas diversas, caso de Igor, jovem que assumiu o desejo de vir a trabalhar apenas na área do teatro - Olga, mas, dois educandos não incluíram definitivamente em seus projetos de futuro a ocupação de ator, seja associada ou não a outras possibilidades de ocupação profissional - Ivan e Nicolas.

Igor (18), por exemplo, por se deparar com resistências de seus pais para se dedicar ao fazer teatral e ao teatro, ingressou em curso superior de artes visuais e a partir desse lugar deu a entender que de alguma forma atendia ao projeto dos pais e também aos seus planos de futuro, pois entende que poderá combinar a atividade do magistério com a do ator e, assim, ter alguma independência e estabilidade financeira:

E da instabilidade financeira. 'Vai fazer teatro e o que você vai fazer depois?' (Risos). Essa foi uma questão que eles levantaram.

Eu fui fazer faculdade porque minha mãe queria que eu fizesse alguma faculdade. Aí eu pensei: "o que eu vou fazer?". Eu trabalhava como designer. E abriu pra artes visuais, até então eu trabalhava meus pais achavam que artes visuais era pra trabalhar como designer. Mas não tem nada a ver. Aí, eu comecei fazer a faculdade de artes, abre pra várias áreas. Música, dança, teatro, cultura, fotografia, escultura e licenciatura. Então, pra mim, já é muito importante, porque eu vou poder dar aula, depois. [...] Porque falta professor!

Às vezes, eu acredito que eu não vou conseguir me manter, mas é uma questão mais interna, sabe? Talvez eu não vou chegar a ser um grande ator!

Olga (20), Ivan (17) e Nicolas (17) declinaram planos distintos quanto a futuro profissional: enquanto a jovem demonstrou se sentir privilegiada por realizar o curso de teatro, projetando o desejo de vir atuar como atriz, o seus pares masculinos falaram de outros projetos, Nicolas, inclusive avaliou a possibilidade de mudança de área de quanto ao tema do projeto de ocupação profissional.

De modo enfático, a educanda assim se referiu a seus planos de futuro ocupacional:

Eu pretendo continuar como atriz, quero ganhar com isso. E eu gosto de escrever, eu acho que posso trabalhar os meus textos e viver outros personagens. [...] E eu gosto muito de pôr no currículo que eu fiz teatro. [...] Tem essa visão de quem faz teatro, sabe lidar com o público. Porque ajuda em outras coisas e ajuda a chegar onde eu quero. Porque eu quero fazer novela e também fazer teatro!

Ivan comentou que adotar uma profissão relacionada à arte seria uma possibilidade, todavia, ele também declarou que se encontrava dividido entre prestar o vestibular para o curso de Artes Cênicas ou o de Letras. Ao analisar as possibilidades de ingresso num curso 
superior, o jovem argumentou que ingressar em um curso de Letras lhe traria vantagens, na medida em que poderia vincular o teatro à sua atuação como profissional da docência.

[...] muitas pessoas falam: "Ah, vai virá ator, vai viver do quê? Vai morrer de fome!" Mas não, tem algum incentivo, tem, porém é pouco, é pouco que tem. [...] Mas não é que não role essa possibilidade de eu seguir carreira como ator, eu gosto da profissão em si, porém, eu tenho um sentimento meio humanista, gosto de ajudar as pessoas. Eu sei que com o teatro eu conseguiria ajudar, porém eu enxergo em Letras, indo pras escolas, uma possibilidade ainda maior de talvez mudar um pouquinho a história, de mudar um pouquinho a vida de alguém, o país... Eu tenho essas ideologias doidas assim (risos).

Nicolas, ao mostrar-se inseguro em relação ao término de sua passagem pelo IRC, revelou que muito possivelmente poderia decidir por uma reversão para cursar e vir atuar na área da Nutrição:

Eu acho que em qualquer área que eu for seguir, eu vou utilizar o teatro. Porque o teatro serve pra tudo!

Eu tava pensando, depois que terminasse o teatro... não sei! É que a gente depende muito do IRC. Se eles falarem que a gente vai continuar a peça... Se a gente continuar, eu talvez continue e fique nisso, e talvez leve muito mais a sério. Mas tava pensando em fazer Nutrição. Caso acabasse, caso não for continuar a peça, acabo indo pra outra área, $[. .$.$] nada a ver com o teatro...$

Natália(18) mostra se indecisa entre seguir a música e o teatro. Segundo a jovem ainda precisa "ver se é isso que eu quero pra vida, música, teatro ou os dois". Mesmo assim sentese um pouco mais inclinada à música, pois é algo que "está no seu interior" e da qual dificilmente "se desapegará".

N- É uma questão de oportunidade. Tenho primeiro em música e depois em teatro, ou o contrário... ou primeiro em teatro e depois em música. No que abrir primeiro pra mim eu vou.

P- Então você gosta de fazer as duas coisas?

N- Sim eu gosto de fazer as duas coisas, mesmo que música seja mais.

P- Faculdade você não pensa em nada

N-Não por enquanto, Musicalização talvez, mas não é uma necessidade tipo pra agora.

Em relação às possibilidades de trabalho no campos das artes, a jovem acredita que para seguir carreira será preciso mudar-se para outra cidade, como São Paulo, por exemplo:

N-Acho que dá, mas não aqui em Ribeirão. Talvez em São Paulo. Sei lá... Aqui você oferece um ingresso pra pessoa a pessoa fala que não gosta de teatro, nunca entrei no teatro. Eu acho que meio que é uma cultura daqui as pessoas não serem tão ligadas a arte. Talvez um motivo de estranhamento e 
as pessoas dizerem que sou louca quando eu falo que quero ser artista. Sei lá!Eu acho muito complicado aqui. Não que são Paulo seja mais fácil, sei lá! $\mathrm{P}-\mathrm{E}$ de onde vem essa opinião?

E- Acho que de observação e de tanto as pessoas falarem: se você quer ser artista tem que ir pra são Paulo.

Por fim, Nádia (27) e Marina (29), já mais próximas da idade adulta e tendo conquistado alguma independência financeira (Singly, 2004, 2005), demonstraram ter planos profissionais distintos em relação a todos os demais jovens que participaram do estudo: a primeira projetava trabalhar em ações de marketing e intervenções empresariais em áreas das artes cênicas, tendo em vista a insegurança em relação à profissão de ator.

Marina (29), casada e já tendo conquistado certa independência financeira e em relação aos seus pais, falou-nos do propósito de entrelaçar as práticas do fazer teatral, os valores religiosos - cristãos e as habilidades como docente de educação física de maneira a desenvolver iniciativa missionária

A gente vai fazer uma escola de artes, porque a gente quer, na verdade, trabalhar com missões, ser missionários, que é você levar a palavra de Deus, dentro de algumas coisas que você tenha o chamado, dentro da educação e das artes. Dentro da educação, aquilo que é da educação física, os jogos, as brincadeiras populares que eu já trabalho.

Então, pra isso, a gente vai se filiar a uma agência missionária, [...] uma escola de artes, que vai ser uma escola de arte bilíngue, para pessoas do mundo todo, quem quiser fazer essa escola de artes lá.

A partir de elementos extraídos dos diálogos que mantivemos com os doze jovens educandos, pudemos apreender e analisar as influências dos processos socializadores que vivenciaram em diferentes círculos sociais - família, escola básica, igrejas de diferentes confissões religiosas, grupo de pares, para escolherem e se engajarem naquela específica proposta de educação. Diante do mesmo material, pudemos dar provas das contribuições e apoios que o curso do IRC ofereceu a distintas dimensões da experiência juvenil de cada um dos doze educandos, em diferentes domínios espaço/temporais que transitavam autoconhecimento, aceitação e respeito à alteridade ou "olhar externo", enriquecimento educacional e cultural, fortalecimento da participação no espaço público, adensamento de processos de identização, (re)conhecimento, domínio e aceitação do corpo, do corpo do jovem e do corpo do ator em quanto possibilidade futura (BOAL, 1980; AZEVEDO, 1990; FABBRINI \& MELUCCI, 1992; MELUCCI, 2004), entre outras dimensões existenciais e sociais, revelando a significativa contribuição daquele curso e seu coletivo aos processos de autonomia e individuação dos jovens pesquisados. 
Em relação aos planos de futuro profissional que explicitaram, em possíveis ocupações na área do teatro e do fazer teatral, os sujeitos-educandos da pesquisa apresentaram narrativas que se aproximara, e alguns deles discorreram sobre perspectivas/expectativas futuras que são singulares, tendo em vista a posição que se encontram no curso da vida e suas principais características, mas também em função dos valores que internalizaram em percursos socializadores no meio familiar de origem, no curso de iniciação teatral do IRC e, ainda, a partir de avaliações que tinham sobre o mercado de trabalho para o ator/atriz na realidade social da localidade em que estão inseridos e também em âmbito nacional. Porém, em todos os depoimentos, encontramos referências às contribuições da proposta educativa do Instituto para os propósitos educativos e profissionais de cada um deles.

Os excertos das falas dos jovens educados acima expostos permitem que se faça a consideração que além dos suportes oferecidos pelo curso do IRC para diferentes dimensões e domínios das experiências dos sujeitos juvenis pesquisados, eles também explicitaram os sentidos das contribuições daquele processo educativo e socializador para conceberem planos de futuro profissional que venham a adensar seus projetos de independência, autonomia e individuação (SINGLY, 2004; 2005; MARTUCCELLI, 2012). 


\section{CONSIDERAÇÕES FINAIS}

Ao chegarmos ao item final deste texto, faz-se necessário recuperar, uma vez mais, a questão que deu origem a presente investigação no campo da pesquisa educacional: no ponto de partida, nosso propósito foi o de encontrar respostas a seguinte pergunta: que contribuições uma iniciativa de educação não escolar na área do fazer teatral poderia oferecer aos processos de socialização, independência e autonomia de jovens - homens e mulheres, na atualidade?

Uma das orientações assumidas no estudo foi encontrada em texto de Singly (2004; 2005) quando analisa os desafios que os jovens devem encarar em seus processos de individuação: eles devem conquistar algum nível de "desfiliação" em relação aos pais e necessitam se apoderam tanto da dimensão da independência como da autonomia, nas circunstâncias históricas que marcam suas experiências (SINGLY, 2005, p. 111, tradução livre).

Para encontrar respostas à pergunta do estudo decidiu-se por interagir e dialogar com doze (12) jovens, do sexo feminino e masculino, com entre 17 e 29 anos de idade, participantes de "curso de iniciação em teatral" concebido e oferecido por organização cultural não governamental - o Instituto Ribeirão em Cena - IRC, localizado na cidade de Ribeirão Preto, interior do estado de São Paulo.

A escolha da atividade educativa não escolar ligada ao teatro e ao seu fazer ocorreu em virtude das potenciais contribuições que ela poderia oferecer a diferentes dimensões de indivíduos situados em diferentes "idades" do curso da vida, como por exemplo, autoconhecimento, aprofundamento do processos de subjetivação e autonomia (BOAL, 2002), reconhecimento do corpo como integralidade - físico e pensamento (AZEVEDO,2004), construção de habilidades e capacidades próprias a teatralidade (COURTNEY, 2003; BOAL, 2002).

Nas atividades de campo, contou-se com a contribuição de jovens que discorreram sobre suas experiências infantis, adolescentes e juvenis, indivíduos oriundos de famílias de diferentes estratos da classe média da cidade Ribeirão Preto, representantes das novas gerações de brasileiros que atingiram/concluíram a escolaridade média ou se integraram - ou já tinham finalizado - a educação superior, e para alguns deles a integração à esfera do trabalho constituía-se uma experiência que vinham acumulando desde a adolescência.

E seus depoimentos, os jovens-educandos revelaram que a chegada e a integração ao curso de iniciação teatral do IRC decorreram de processos socializadores que vivenciaram em distintos círculos - a família de origem, escolas particulares de ensino fundamental, espaços religiosos de diferentes confissões, grupos de amigos, entre outros. 
Para parte deles, a escolha e participação no curso do IRC se deram com o incentivo e respaldo de diferentes membros do núcleo familiar, para outros o engajamento naquela experiência educativa ocorreu em meio a tensões e conflitos - e por vezes negociações vividos com membros da família, sobretudo com a figura paterna. Porém, nos dois casos, o que se pode apreender é que a aposta pela proposta do fazer teatral decorreu de uma "vontade intrínseca" ou ação "voluntária" de todos (REYMOND, 2003; SPOSITO, 2008), vontade que, em muitos deles, pode ser lida como um exercício de conquista de autonomia em relação ao mundo da família.

Quando questionados sobre os benefícios que o curso do IRC lhes proporcionara, as respostas obtidas conformaram um rico leque de contribuições e habilidades, admitidas como fundamentais à múltiplas e diferentes dimensões de suas vivências juvenis, em diferentes domínios sociais e culturais, e, segundo eles, as contribuições também ampliaram suas perspectivas futuras de atuação profissional nas áreas do teatro, do fazer teatral, ou ainda em outros setores de atividade laboral.

Contudo, tal como os jovens envolvidos com a formação em artes cênicas e investigados por Villar e Villar (2007), os sujeitos deste estudo também não deixaram de expressar preocupações quanto às dificuldades que podem vir a enfrentar para um engajamento profissional exclusivo na área do teatro ou das artes cênicas, razão pela qual aventaram a possibilidade de associar uma ocupação no mundo do teatro - ou das artes cênicas - com outras atividades ocupacionais em outras áreas, a exemplo da docência em diferentes etapas da educação básica.

Nas narrativas que formularam os jovens-educandos não nos autoriza a afirmar que aquela proposta socializadora e educativa teve igual peso e sentido aos seus processos de "desfiliação" e independência em relação aos seus pais, pois apenas uma jovem demonstrou ter conquistado tal dimensão do processo de individuação, os demais encontravam-se, ainda, sob o estatuto normativo de "filhos/filhas de" (SINGLY, 2004; 2005).Porém, elas também tornaram evidente que, imersos em um contexto social e nacional em que as artes e seu aprendizado da arte - inclusive o fazer teatral - ainda ocupam um lugar marginal ou periférico na educação escolar básica (CHARLOT,2011), o curso do fazer teatral fazia a juventude de todos, contribuindo para o enriquecimento e diversificação de seus processos de interação social, de socialização, de conhecimento de si/subjetivação, de produção identitária (FABBRINI \& MELUCCI, 1992), e conquista da autonomia em relação ao mundo adulto e algumas de suas instituições. 
A leitura e analise de suas narrativas, sobre os apoios oferecidos pelo curso do IRC, nos devolveram a Martuccelli (2007), quando nos explicou que "ser autônomo é ser capaz de produzir sua própria lei, frequentemente a partir de elementos externos, (...) após um exame de consciência, em regras pessoais", pois a autonomia não anula a dependência "em relação ao mundo, mas muda seu significado, posto que a dependência se transforma, de alguma forma, em vínculo aceito e reformulado pelo indivíduo mesmo (MARTUCELLI 2007 p. 39, tradução livre).

Neste texto não foi possível explorar e analisar o conjunto plural de contribuições socializadoras e educativas que o curso iniciação teatral ofereceu aos jovens-educandos que entrevistamos. Porém, acreditamos que o que foi exposto até aqui, sobretudo as contribuições que apresentamos no capítulo anterior, permite a defesa da ideia de que a função social daquela proposta de educação significou para cada um dos jovens muito mais que o aprendizado e apropriação de técnicas, saberes, conhecimentos próprios a linguagem teatral.

Neste sentido, as vozes dos jovens-educandos conferiram plausibilidade a hipótese inicial deste estudo e ofereceram mais que indícios para que compreendamos a importância que pode ter processos de formação artística não escolar, na linguagem teatral, para os jovens mergulharem na experiência da vida, como afirmam Fabbrini \& Melucci(1992) encontrarem uma "verdade sobre o mundo e sobre si mesmas" e inventarem uma "vida que valha a pena ser vivida" . 


\section{REFERÊNCIAS}

ALCÂNTARA JÚNIOR, José O. O conceito de sociabilidade em Georg Simmel : Ciências Humanas em Revista (UFMA), v. 3, p. 31-40. São Luís: 2005.

ALMEIDA, Elmir, Os estudos sobre grupos juvenis: presenças e ausências: SPOSITO, M. (Coord.). Estado da arte sobre juventude na pós-graduação brasileira: educação, ciências sociais e serviço social (1999-2006). Belo Horizonte: Argvmentvm, 2009. v.2.

ALVES-MAZZOTTI, Alda Judith, Relevância e aplicabilidade da pesquisa em Educação : Cadernos de Pesquisa, Fundação Carlos Chagas, n. 113, julho/2001, p.39-50.

AMARAL, Ana Lúcia. Pertencimento. Disponível em: <http://escola.mpu.mp.br/dicionario/ tiki-export_pdf.php>. Acesso em: 20 mar. 2016.

ARIÈS, Philippe. História social da criança e da família. 2 ed. Rio de Janeiro: Guanabara, 1986.

ATTIAS-DONFUT, Claudine. Jeunesse et conjugaison des temps. Sociologie et sociétés. Vol. XXVIII, número 1, 1996

AZEVEDO, S. M. O papel do corpo no corpo do ator. São Paulo: Perspectiva, 2004.

BOAL, Augusto. O arco-íris do desejo. Civilização Brasileira. Rio de Janeiro. 1996. Brasileira, 2008.

. Jogos para atores e não-atores. $11^{\mathrm{a}}$ ed. Rio de Janeiro, Civilização

BOURDIEU, Pierre. La 'jeunesse' n'estqu'un mot: BOURDIEU, Pierre. Questions de sociologie. Paris:LesÉditions de Minuit, 2002.

As contradições da herança: LINS, Daniel S. Cultura e subjetividade: saberes nômades. Campinas: Papirus. 1997

As contradições da herança: NOGUEIRA, M.A.; CATANI, A. Pierre Bourdieu: escritos de educação. $4^{\text {a }}$. ed. Petropólis, RJ : Vozes, p. 231-237.1998

BRANDÃO, Carlos Rodrigues. O que é educação. 5 ed. Rio de Janeiro: Brasiliense, 1982. 7 12p. (Coleção Primeiros Passos).

Perguntas, pesquisas. Para Quem?Para quê: Processos educativos em práticas

sociais: pesquisas em educação: EdUFScar.São Carlos. 2014

BRASIL. LDB: Lei de Diretrizes e Bases da Educação Nacional: lei no 9.394, de20 de dezembro de 1996, que estabelece as diretrizes e bases da educação nacional. 5. ed. Brasília: Câmara dos Deputados, Coordenação Edições Câmara, 2010.

BROUGÈRE, Gilles; BÉZILLE, Hélène. De l'usage de la notion d'informel dans lechamp de l'éducation: Revue Française de Pédagogie, 158, 113-160, janvier-mars, 2007. 
BUCHER \& SOMMER: O Que Causa a Gagueira? PLoS Biology, Fevereiro 2004, Volume 2. <Disponível em http://www.gagueira.org.br/arquivos/causa_da_gagueira.pdf. Acessado em $04 / 2016>$

CÂNDIDO, Antônio. A estrutura da escola: PEREIRA, Luiz, FORACCHI, Marialice M. Educação e sociedade: leituras de sociologia da educação. São Paulo: Nacional, 1964. p. 107-128.

CHARLOT, B. Dança, teatro e educação na sociedade contemporânea. Ribeirão Preto, SP: Ed. Alphabeto, 2011.

COURTNEY, Richard. Jogo, teatro e pensamento: as bases intelectuais do teatro na educação. São Paulo: 1980.

DAYRELL et al. Juventude, pobreza e ações educativas no Brasil: Espaços públicos e tempos juvenis: um estudo de ações do poder público em cidades de regiões metropolitanas brasileiras, 1 ed. São Paulo: Global Editora, 2007.

DE LEÓN, Oscar D. Adolescência e juventude: das noções às abordagens: FREITAS M. V Juventude e adolescência no Brasil: referências conceituais. São Paulo: Ação Educativa, 2005 .

DELORY-MOMBERGER, Christine. Abordagens metodológicas na pesquisa biográfica. In:Revista Brasileira de Educação. v.7, n. 51, setembro-dezembro, 2012. (p. 523-536) < Disponível em: http://www.scielo.br/pdf/rbedu/v17n51/02.pdf Acesso em: 12/09/2014

DESGRANGES, Flávio. Pedagogia do Teatro: Provocações e Dialogismo. São Paulo: 3 ed.Hucitec: edições Mandacaru, 2011.

DICAS MULHER. Conheça o Ribeirão em Cena. 2011. Disponível em $<$ http://dicasmulher.com.br/artigo/conheca-o-ribeirao-em-cena/>. Acesso em: 20 jun. 2015.

DURKHEIM, Émile. Educação e Sociologia. Edições 70 Lda, Lisboa, 2007.

FISCHER, Ernst. A Necessidade da Arte. 5. ed. Rio de Janeiro: Zahar Editores, 1976.

FABBRINI, A; MELUCCI, A. Lètádelloro: adolescenti tra sogno e desperienza. Milano: Goangiacomo Feltrinelli Editores, 1992.

FERREIRA, V. S. Artes e manhas da entrevista compreensiva: Saúde e Sociedade, 23 (3), 979-992. 2014

FREIRE, Paulo. Ação Cultural para a Liberdade. 5 ed.Rio de Janeiro: Editora Paz e Terra. 1981.

GOHN, M.G.M. Educação Não Formal e cultura política: impactos sobre o associativismo sobre o terceiro setor. 4 ed. São Paulo: Cortez, 2008 
GOHN, M. G. Educação não-formal, participação da sociedade civil e estruturas colegiadas nas escolas. in:Ensaio: avaliação das políticaspúblicaseducacionais. Rio de Janeiro, v.14, n.50, p. 27-38, jan./mar. 2006, diponivel em:

http://www.scielo.br/pdf/ensaio/v14n50/30405.pdf . Acessado em 05 mar.2014.

GOMES, Marcelo Bolshaw. Entrevista Biográfica. III Congresso Internacional sobre Pesquisa (Auto)biográfica. Natal: Edfurn, 2008. Disponível em $<$ www.bocc.uff.br/pag/boccgomes-entrevista.pdf $>$ Acesso em 09/10/2014

GOMES, Micael. C. Cortes.Portas Entreabertas: Em busca de uma educação sensível a partir das imagens, espaços e narrativas com teatro-educação. Tese( Doutorado em Educação)Faculdade de Universidade Federal do Estado de São Paulo.São Paulo, 2012

HUIZINGA, Johan. Homo Ludens. 4.ed São Paulo: Perspectiva, 2001.

LOPES, Joana. Pega Teatro. 1.ed. São Paulo: Papirus, 1989.

MARTINS. Heloisa Helena. Metodologia qualitativa de pesquisa: Universidade de São Paulo - Educação e Pesquisa. São Paulo, v. 30, n. 2, p. 289-300, maio/ago. 2004.

MARTUCCELLI, Danilo. Lecciones de sociologia del individuo, Lima, Peru: Pontificia Universidade Catolica del Peru, Departamento de Ciencias Sociales, 2012.

MELUCCI, Alberto. A invenção do presente: movimentos sociais nas sociedades complexas. Petrópolis, RJ, Editora Vozes, 1991.

MUNANGA, K. Negritude e Identidade Negra ou Afrodescendente: um racismo ao avesso? : Revista da Associação dos Pesquisadores(as) Negros(as) - ABPN, v. 4, n. 8, p. 06-14, jul./out. 2012.

PAIS, José Machado. A construção sociológica da juventude- alguns contributos. Análise Social vol. XXV, 1990.

REYMOND, M. Du Bois. Une etude sur lês liens entre l'educacion formelle et l'educacion non formelle. Conseil de l'Europe, 2003.

RIBEIRÃO EM CENA. Inicial. Disponível em:

$<$ http://www.ribeiraoemcena.org.br/index.php>. Acesso em: 20 jun. 2015.

SANTOS, Marla A. de Oliveira, O pertencimento racial de jovens negros na universidade Zumbi dos Palmares. Dissertação( Mestrado em Educação)Faculdade de Educação, Universidade de São Paulo.São Paulo, 2012

SAUL, Alexandre. Prática teatral dialógica de inspiração freireana: uma experiência na escola, com Jovens e Adultos. Dissertação (Mestrado em Educação). Pontifícia Universidade Católica de São Paulo. São Paulo. 2012

SETTON, Maria da Graça Jacintho. Reflexões sobre a dimensão social da música entre os jovens: Comunicação \& Educação, ano XIV, nº 1,jan/abr, 2009. 
Família, escola e mídia: um campo com novas considerações in: Educação e Pesquisa, São Paulo, v 28, n.1, p. 107-116, jan/jun, 2002.

SILVA, H. H. de C.; SOUZA, N. A. de. Juventude e poder local: um balanço de iniciativas públicas voltadas para jovens em municípios de regiões metropolitanasin:Revista. Brasileira de Educação, Rio de Janeiro, v.11 n.32, mai./aug. 2006. Disponível em: $<$ http://www.scielo.br/scielo.php?script=sci_arttext\&pid=S141324782006000200004> Acesso em: 13 julho. 2014.

SLADE, Peter. O jogo dramático infantil. 3. ed. São Paulo: Summus, 1978.

SPOLIN, Viola. Improvisação para o Teatro. 1 ed. São Paulo: Perspectiva, 1982.

SPOSITO, M.P. Uma perspectiva não escolar do estudo sociológico da escola. Revista da USP, São Paulo, n.57, p. 210-226, mar. /maio 2003.

. Indagações sobre as relações entre juventude e a escola no Brasil:

institucionalização tradicional e novos significados: Jovenes: Revista de Estudios sobre Juventud, México, DF, v. 9, n. 22, jan./jun. 2005.

. Juventude e educação: interações entre a educação escolar e a educação não-formal: Educação \& Realidade, 33(2): 83-98, jul/dez 2008.

. (Org.). SPOSITO, M. Estado da arte sobre juventude na pós-graduação brasileira: educação, ciências sociais e serviço social (1999-2006). Belo Horizonte: Argvmentvm, 2009. v.2.

SZYMANSKI, Heloisa. Entrevista reflexiva: um olhar psicológico sobre a entrevista em pesquisa. In: SZYMANSKI, Heloisa (org.). A entrevista na pesquisa em educação: a prática reflexiva. Brasília: Plano Editora, 2002

UNIVERSIDADE SÃO PAULO.FFCLRP.LEPINJE. Situação da Criança e do Adolescente em Ribeirão Preto: Uma Contribuição ao Conselho Municipal dos Direitos da Criança e do Adolescente no Processo de Definição de Diretrizes para a Formulação de Políticas Públicas Destinadas à Infầncia e a Adolescência. Ribeirão Preto: Faculdade de Filosofia, Ciências e Letras de Ribeirão Preto. Laboratório de Estudos e Pesquisas sobre Infância, Juventude e Educação - LEPINJE, 2012.

WESHMEIER, Nilson. Apontamentos para uma Sociologia da Juventude.In: Revista Cabo-Verdiana de Estudos Sociais, ano 1, N.1, p 8- 26. Jan-Jun 2013.p

VYGOTSKY, L. S. A formação social da mente. São Paulo: Martins Fontes, 1998.

VILLAR E VILLAR, Maria Elena. Experiências Juvenis e ações públicas dirigidas à juventude: artes e trabalho na transmissão geracional.Tese (doutorado em Educação) Faculdade de Educação, Universidade de São Paulo.São Paulo, 2007

VILUTIS, Luana. Cultura e Juventude: A formação dos jovens nos pontos de Cultura. Dissertação (mestrado em Educação) Faculdade de Educação da Universidade de São Paulo. São Paulo.2009. 
VINCENT, G.; Lahire, B.; Thin, D. Sobre a história e a teoria da forma escolar. Educação: RevistaUFMG, 33, p. 7-48, 2001.

VINHA, G.C.G. "Nada pra fazer"! Interesses, processos educativos e suportes presentes nas interações dos jovens com o Projovem Adolescente em Ribeirão Preto - SP.

Dissertação (mestrado em Educação)- Faculdade de Filosofia Ciências e Letras,Universidade de São Paulo- Ribeirão Preto. 2014. 


\section{APÊNDICES}

QUADRO 2 - REFERÊNCIAS DE TRABALHOS IDENTIFICADOS E RECUPERADOS DO BANCO DE TESES DO PORTAL CAPES, 2007-2014

\begin{tabular}{|c|c|c|c|c|c|}
\hline $\begin{array}{l}\text { Ano de } \\
\text { Defesa }\end{array}$ & IES $^{46}$ & Autor(a) & Título do trabalho & $\begin{array}{c}\text { Área do } \\
\text { Conhecimento }\end{array}$ & Nível \\
\hline 2011 & $\mathrm{PUC} / \mathrm{SP}$ & Alexandre Saul & $\begin{array}{l}\text { Prática teatral dialógica de inspiração freireana: uma experiência na escola, com jovens e } \\
\text { adultos }\end{array}$ & Educação & Mestrado \\
\hline 2012 & UFG & Aurisberg Leite Matutino & Caminhos para ver, se ver e ser visto: o grupo de Teatro VenvêParangolé & $\begin{array}{l}\text { Arte e Cultura } \\
\text { Visual }\end{array}$ & Mestrado \\
\hline 2012 & UDESC & Cleber Pereira Borges & $\begin{array}{l}\text { As contribuições do grupo teatral Jovens Atores para as políticas culturais de Diadema } \\
\text { nos anos } 1990\end{array}$ & Teatro & Mestrado \\
\hline 2012 & USP & Denise Diba & $\begin{array}{l}\text { De ponto de drogas à ponto de cultura: juventude, teatro e promoção da saúde - o grupo } \\
\text { Pombas Urbanas em Cidade Tiradentes }\end{array}$ & Medicina & Mestrado \\
\hline 2012 & UFF & Leticia Miranda Paula & $\begin{array}{l}\text { Quem somos nós? Surgimento, identidade e legitimidade na trajetória teatral do grupo } \\
\text { Nós do Morro }\end{array}$ & História & Mestrado \\
\hline 2012 & UNESP & $\begin{array}{l}\text { Micael Carmo Cortes } \\
\text { Gomes }\end{array}$ & $\begin{array}{l}\text { Portas entreabertas: em busca de uma educação sensível a partir das imagens, espaços e } \\
\text { narrativas com teatro-educação }\end{array}$ & Educação & Doutorado \\
\hline 2012 & UFBA & $\begin{array}{l}\text { Rosa Adelina Sampaio } \\
\text { Oliveira }\end{array}$ & $\begin{array}{l}\text { Commmediadell’Arte no sertão da Bahia: uma experiência teatral com jovens do } \\
\text { assentamento de reforma agrária Poço Longe }\end{array}$ & Artes Cênicas & Mestrado \\
\hline 2012 & Fiocruz & $\begin{array}{l}\text { Thelma Lopes Carlos } \\
\text { Gardair }\end{array}$ & $\begin{array}{l}\text { Integrando a percepção de estudantes à criação de peça teatral: uma alternativa de } \\
\text { educação científica em diálogo com as artes }\end{array}$ & $\begin{array}{c}\text { Ensino de } \\
\text { Biociências }\end{array}$ & Mestrado \\
\hline 2012 & UFU & Vanessa Bianca Sgalheira & $\begin{array}{l}\text { Vias de expressão em adolescer: análise da oficina de teatro com adolescentes e jovens } \\
\text { do Complexo Morumbi em Uberlândia-MG }\end{array}$ & Artes & Mestrado \\
\hline
\end{tabular}

\footnotetext{
${ }^{46}$ IES - Instituição de Ensino Superior
} 
1. ALEXANDRE SAUL. PRÁTICA TEATRAL DIALÓGICA DE INSPIRAÇÃO FREIREANA:UMAEXPERIÊNCIA NA ESCOLA,COM JOVENS E ADULTOS' 01/12/2011 114 f. MESTRADO ACADÊMICO em EDUCAÇÃO (CURRÍCULO)

Instituição de Ensino: PONTIFÍCIA UNIVERSIDADE CATÓLICA DE SÃO PAULO

Biblioteca Depositária: BIBLIOTECA DA PUC/SP

Palavras-chave: Paulo Freire; Teatro; Currículo

Resumo: No contexto dessa pesquisa, destaca-se a compreensão da arte como forma de conhecimento com implicações éticas e políticas e nessa perspectiva assume-se que o teatro pode ser um valioso instrumento de luta e humanização, com vistas à transformação da realidade. Essa pesquisa propõe-se a responder a seguinte indagação: como o teatro pode ser uma prática artístico-educativa que estimule a reflexão crítica, com a intenção de que, uma comunidade escolar possa compreender cada vez melhor suas situações-limites e se mobilizar para superá-las? Por meio da observação participante, de abordagem qualitativa, foi sendo construído e trilhado o caminho dessa pesquisa, com a intenção de projetar e experienciar um quefazer teatral inspirado na proposta político-pedagógica de Paulo Freire. Trabalhou-se com as ideias centrais do pensamento freireano para codificar, em linguagem teatral, e debater com uma comunidade escolar, da cidade de São Paulo, as situações-limites por ela vivenciadas. Objetivou-se desenvolver um teatro dialógico na qual o Diálogo assumiu um papel central no que se refere à construção de conhecimento e a uma prática emancipatória. O quadro teórico dessa investigação teve como suporte, em especial, as ideias de Freire, Boal e Brecht. A análise dos resultados da pesquisa foi feita com o crivo conceitual que subsidiou a criação do que foi considerado, nessa dissertação, um teatro dialógico. Os resultados demonstraram a viabilidade e a relevância de uma experiência como essa, na escola, destacando-se seu potencial de ampliar as possibilidades de leitura da realidade dos participantes e gerar ações de cidadania ativa. Em acréscimo, os resultados apontaram implicações educacionais para o currículo escolar, acenando com possibilidades de enraizamento da prática teatral realizada.

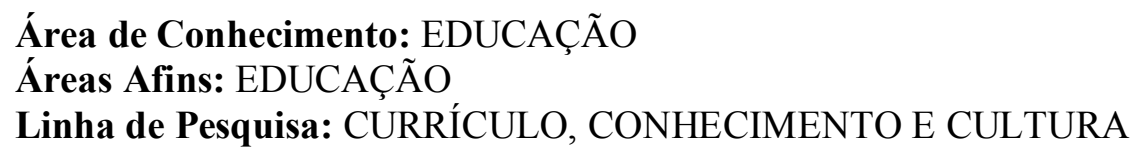




\section{AURISBERG LEITE MATUTINO. CAMINHOS PARA VER, SE VER E SER VISTO: O GRUPO DE TEATRO VENVÊ PARANGOLÉ ' 01/05/2012 145 f. MESTRADO ACADÊMICO em ARTE E CULTURA VISUAL}

Instituição de Ensino: UNIVERSIDADE FEDERAL DE GOIÁS

Biblioteca Depositária: BIBLIOTECA CENTRAL - UFG

Palavras-chave: juventude urbana, visualidades; Grupo de Teatro VenvêParangolé

Resumo: Este trabalho lança luz sobre as práticas socioculturais do Grupo de Teatro VenvêParangolé, localizado no Setor Madre Germana I, em Aparecida de Goiânia, Goiás. As narrativas apresentadas dizem respeito às suas ações e estão articuladas aqui de modo a abordar as formas de ver, se ver e ser visto produzidas pelo grupo em seu trabalho coletivo, entendido nos termos de uma prática artística e educativa sob a motivação principal de constituir vetor de transformação social. Enfoco, portanto, as visualidades produzidas pelo grupo em sua tentativa de reconstruir a imagem socialmente estereotipada, comumente atribuída a jovens de periferia, e como forma de superação de desigualdades e mudança social. As aproximações com o grupo foram muitas e de formas variadas: encontros para discussão, filmagens e gravações; interpretação dos artefatos cedidos pelo grupo (especialmente os que integram uma caixa do grupo); anotações em um diário de campo; relatórios de pesquisa, entre outros. Os desdobramentos da pesquisa me permitiram compreender, afinal, que a prática sociocultural do grupo está direcionada para a busca de alternativas para enfrentar o problema da desigualdade e das injustiças sociais por meio da arte; o que os jovens parangolés procuram, de fato, são formas de representatividade atuantes e que se insiram em uma luta coletiva por um ?mundo melhor?, contornada por um trabalho comunitário, participativo e participante.

Área de Conhecimento: ARTES

Áreas Afins: ARTES

Linha de Pesquisa: Culturas da Imagem e Processos de Mediação 


\title{
3. CLEBER PEREIRA BORGES. AS CONTRIBUIÇÕES DO GRUPO TEATRAL JOVENS ATORES PARA AS POLÍTICAS CULTURAIS DE DIADEMA NOS ANOS 1990 ' 01/08/2012 154 f. MESTRADO ACADÊMICO em TEATRO
}

\author{
Instituição de Ensino: UNIVERSIDADE DO ESTADO DE SANTA CATARINA
}

Biblioteca Depositária: BIBLIOTECA CENTRAL DA UDESC

Palavras-chave: Jovens Atores. Políticas Culturais. Teatro. Diadema.

Resumo: Este trabalho busca compreender as contribuições do grupo teatral Jovens Atores no âmbito das políticas culturais implementadas em Diadema/SP a partir dos anos 1990. De início, apresenta noções e proposições sobre políticas culturais por meio da revisão da bibliografia especializada no tema. Indica autores e discussões pertinentes ao assunto e elege, para efeito de análise deste trabalho, o conceito de políticas culturais como sinônimo de públicas para a cultura. Os conceitos de políticas culturais expostos servem de parâmetro para o caso concreto da cidade de Diadema. Para tanto, o trabalho aborda seu contexto sociopolítico procurando identificar os indícios que motivaram as sucessivas gestões, a partir dos anos 1980, a implantar políticas públicas de forma sistemática para a diminuição de desigualdades sociais e como isso impactou no campo cultural. Ressalta, ainda, a problemática da violência presente na própria constituição da cidade à luz de estudos concernentes ao tema, indicando certa contradição entre o processo de melhorias sociais ao mesmo tempo em que há significativo aumento da violência. Paralelamente a isso, é apontado o contexto cultural de Diadema com a finalidade de refletir de que forma a cidade procurou combater o estigma de cidade violenta por meio da promoção cultural na gestão municipal do período 1993-1996. É nesse momento que as manifestações teatrais em Diadema voltam a florescer, a exemplo do que já que houvera nos anos 1970 com o Teatro-Escola. Os Jovens Atores de Diadema, nascidos de uma oficina teatral promovida pela mediação cultural, torna-se o expoente dessa arte na cidade a partir de 1995. O trabalho trata das montagens teatrais do grupo com a finalidade de extrair daí as contribuições e o legado por ele deixado na cidade. Aponta a importante metodologia de narração de histórias pessoais e da cidade na construção de um dos espetáculos e o quanto seu resultado impactou sobre o público. Ressalta ainda a relação qualidade artística e identidade com um dos fatores de sucesso do grupo. Como considerações finais, o trabalho aponta as contribuições do grupo para as políticas culturais questionando os limites dessas políticas.

\author{
Área de Conhecimento: TEATRO \\ Áreas Afins: TEATRO \\ Linha de Pesquisa: Teatro, Sociedade e Criação Cênica
}


4. DENISE DIBA. DE PONTO DE DROGAS À PONTO DE CULTURA: JUVENTUDE, TEATRO E PROMOÇÃO DA SAÚDE - O GRUPO POMBAS URBANAS EM CIDADE TIRADENTES' 01/08/2012 251 f. MESTRADO ACADÊMICO em MEDICINA (MEDICINA PREVENTIVA)

Instituição de Ensino: UNIVERSIDADE DE SÃO PAULO

Biblioteca Depositária: FACULDADE DE MEDICINA USP

Palavras-chave: Adolescente, empoderamento, juventude

Resumo: A presente dissertação é fruto do interesse da pesquisadora pela linguagem teatral e suas conexões com o campo da saúde. Neste recorte, objetivamos conhecer de que maneira as atividades de teatro têm sido compreendidas e operacionalizadas no trabalho realizado nos últimos anos pelo Instituto Pombas Urbanas no Centro Cultural Arte em Construção, distrito de Cidade Tiradentes, analisando se e como elas podem estar relacionadas com a Promoção da Saúde de jovens participantes do projeto. Trata-se de uma pesquisa qualitativa, do tipo etnográfica, onde acompanhamos durante um ano o trabalho realizado pelo grupo de teatro Pombas Urbanas nesta Organização da Sociedade Civil de Interesse Público (OSCIP) que volta seus trabalhos para a comunidade. Foi realizada observação etnográfica composta por observação participante, dezessete entrevistas semi-estruturadas com os atores do grupo Pombas Urbanas, jovens do Núcleo Teatral Filhos da Dita, da Turma Jovem e da Turma Iniciante, além de análise documental. Analisamos qual a relação existente entre a participação nestas atividades, a redução da vulnerabilidade e o empowerment considerados como componentes importantes da Promoção da Saúde. Como resultados apontamos que, no caso estudado, a vivência teatral tem contribuído para a promoção da saúde dos participantes, especialmente através da metodologia de teatro comunitário utilizada pelo grupo, com ênfase na escuta, estímulo ao diálogo e relações não hierárquicas ou competitivas entre os participantes. Esta vivência tem possibilitado que eles considerem estar aumentando seu autoconhecimento e sintam-se protegidos e apoiados uma vez que consideram que a vivência teatral tem possibilitado uma sólida ampliação de sua rede de apoio social. Também tem permitido a valorização de suas origens, o desenvolvimento de habilidades sociais e que tenham maior consciência crítica em relação a questões como consumismo, trabalho/lazer, uso de álcool e/ou drogas e questões relacionadas à sexualidade, como o uso de preservativos e a escolha de parceiros. Toda essa vivência tem gerado saúde porque, integradamente às questões já expostas, tem permitido que os jovens reflitam e optem por seus projetos de vida de forma que se sintam mais realizados e satisfeitos, além de realizarem importantes intervenções e ações políticas na comunidade em que vivem.

\author{
Área de Conhecimento: MEDICINA PREVENTIVA \\ Áreas Afins: SAÚDE COLETIVA \\ Linha de Pesquisa: ATENÇÃO PRIMÁRIA E CUIDADO EM SAÚDE
}


5. LETICIA MIRANDA PAULA. QUEM SOMOS NÓS? SURGIMENTO, IDENTIDADE E LEGITIMIDADE NA TRAJETÓRIA TEATRAL DO GRUPO NÓS DO MORRO ' 01/05/2012 136 f. MESTRADO ACADÊMICO em HISTÓRIA

Instituição de Ensino: UNIVERSIDADE FEDERAL FLUMINENSE

HTTP://WWW.HISTORIA.UFF.BR/STRICTO/TD/1591.PDF

Palavras-chave: História social; cultura; teatro; Grupo Nós do Morro

Resumo: O Grupo Nós do Morro foi criado em 1986, na favela do Vidigal, a partir do contato entre profissionais de teatro com os jovens moradores, através dos anos, se transformou em uma das mais importantes iniciativas no âmbito de trabalhos artísticos e sociais criados e desenvolvidos no Brasil. A proposta inicial do grupo era um teatro feito da comunidade para a comunidade, sendo assim, as peças deste período abordavam temas que refletiam a realidade dos moradores com o objetivo de formar uma plateia local. Mas que plateia era essa? No final dos anos setenta, a construção de prédios na subida do Vidigal fez surgir uma nova vizinhança composta por pessoas de classe média e artistas, entre eles o fundador e diretor geral do grupo, Guti Fraga. Compartilhando do mesmo universo geográfico, a classe média convivia com os moradores mais humildes, ocupantes da parte média e alta do morro. São para estes atores sociais que o discurso do grupo se volta, buscando atrair um público pouco habituado a frequentar teatro. Com o passar do tempo, o Nós do Morro sente a necessidade de perder sua essência amadora e tentar obter reconhecimento da classe profissional. A construção de uma sede própria, após a ocupação de vários espaços dentro do Vidigal, como uma igreja desativada e os fundos de uma escola municipal, reflete essa necessidade do grupo afirmar sua autonomia artística. E foi aí, que, em 1996, o Nós do Morro inaugurou um teatro com capacidade para oitenta espectadores, o Teatro do Vidigal. Com a peça escolhida para inaugurar o teatro, Machadiando, reunião de textos de Machado de Assis, o grupo conquistava o primeiro prêmio oficial, o Prêmio Shell. O prêmio foi recebido com grande entusiasmo pela companhia, que, a partir deste momento, acreditava estar legitimada no mercado não mais em função de um trabalho social realizado em uma favela carioca. Porém, o Nós do Morro vencia como "categoria especial", ou seja, a crítica especializada valoriza mais um trabalho comunitário do que o espetáculo em si. Somente anos mais tarde, em 2002 é que o grupo ganharia o Prêmio Shell por uma categoria tradicional com a apresentação da peça Noites do Vidigal, primeira montagem do grupo a estrear fora da favela de origem. O espetáculo foi bem recebido pela crítica e foi contemporâneo, também, a participação dos atores no filme Cidade de Deus. O sucesso do longa de Fernando Meirelles impulsionou a carreira de vários integrantes do Nós do Morro para produções no cinema e na televisão. Diante destes acontecimentos pretendemos discutir a legitimidade conquistada pelo Nós do Morro e o significado desta legitimidade para os diversos atores sociais que se apropriam do trabalho do grupo.

Área de Conhecimento: HISTÓRIA

Áreas Afins: HISTÓRIA

Linha de Pesquisa: CULTURA E SOCIEDADE 
6. MICAEL CARMO CORTES GOMES. PORTAS ENTREABERTAS: EM BUSCA DE UMA EDUCAÇÃO SENSÍVEL A PARTIR DAS IMAGENS, ESPAÇOS E NARRATIVAS COM TEATRO-EDUCAÇÃO' ' 01/03/2012 353 f. DOUTORADO em EDUCAÇÃO ESCOLAR

Instituição de Ensino: UNIVERSIDADE EST.PAULISTA JÚLIO DE MESQUITA FILHO/ARARAQUARA

Biblioteca Depositária: UNESP

Palavras-chave: Sócio- Antropologia do Cotidiano. Pedagogia do Teatro:

Resumo: Este estudo teve o objetivo analisar pistas de uma Educação Sensível por meio de uma Pedagogia do Teatro a partir de um "saber e saber-fazer" Teatro-Educação em práticas educativas. O trabalho fundamenta-se na Sócio- Antropologia do Cotidiano, tendo por referência a Sociologia do Cotidiano, os estudos da razão sensível de Michel Maffesoli. Com base nos procedimentos metodológicos, optou-se pela pesquisa Etnográfica, delimitando o terreno ao qual o pesquisador permaneceu como observador-participante, isto é, no interior de um galpão denominado como "Escola do Presídio" do Interior do Estado de São Paulo e os informantes dessa investigação, os "monitores culturais" detentos. Entre os meses de maio de 2008 e novembro de 2009, foram realizadas observações, anotadas em diário de campo, a partir do contato com o grupo local (Centro de Trabalho e Educação e os Monitores - privados de liberdade) bem como um levantamento sobre o cotidiano dessa escola (documentos da instituição, atividades culturais, aulas dos monitores, desenhos, maquetes da escola, fotos e filmagens) e, ao longo dessa investigação, atividades de cunho artístico-pedagógico a partir da inserção da Pedagogia do Teatro: Teatro-Educação, realizadas pelo pesquisador como, por exemplo: Grupo de Estudos; Laboratório do Brincar com Teatro; Pesquisa Cênica (Confecções de Máscaras para a representação de sua dramaturgia autobiográfica de $\mathrm{Si}$ ) e as entrevistas semiestruturadas com os seis monitores envolvidos tanto no trabalho da escola (distribuídos entre as áreas de Alfabetização de Jovens e Adultos, os Ciclos I, II (I - $1^{\mathrm{a}}$ a $4^{\mathrm{a}}$-, II - $5^{\mathrm{a}}$ a $8^{\mathrm{a}}$ - e o Ensino Médio) quanto nessa investigação. Assim, o diário de campo confeccionado permitiu a descrição do universo vivido entre o pesquisador e os seis informantes da pesquisa que estão inseridos. A geração de dados constituiu a partir dos registros audiovisuais (foto etnografia, vido etnografia), observação sistemática, etnobiografia e as entrevistas filmadas. Assim, essa investigação previligiou as imagens, os espaços e as narrativas como possibilidades de evidenciar pistas de uma educação sensível a partir de uma experiênciaartístico-pedagógica e, assim, produzir um conhecimento a partir do nãoracional, dos sentimentos, das emoções, das paixões, das tragédias, dos sentimentos e da ludicidade tendo aí, a razão sensível como sustentação teórica para essa aventura com a Ciência e a Arte, nesse caso, com Teatro-Educação em práticas educativas.

\author{
Área de Conhecimento: EDUCAÇÃO \\ Áreas Afins: EDUCAÇÃO \\ Linha de Pesquisa: Sexualidade, cultura e educação sexual
}


7. ROSA ADELINA SAMPAIO OLIVEIRA. COMMMEDIA DELL ARTE NO SERTÃO DA BAHIA: UMA EXPERIÊNCIA TEATRAL COM JOVENS DO ASSENTAMENTO DE REFORMA AGRÁRIA POÇO LONGE ' 01/03/2012 140 f. MESTRADO ACADÊMICO em ARTES CÊNICAS

Instituição de Ensino: UNIVERSIDADE FEDERAL DA BAHIA

Biblioteca Depositária BIBLIOTECA NELSON ARAÚJO-ESCOLA DE TEATRO

Palavras-chave: Commediadell'Arte. Máscaras. Jovens. Assentamento

Resumo: O presente trabalho se configura como uma pesquisa-ação realizada com os jovens do Assentamento de Reforma Agrária Poço Longe. Na referida pesquisa, são investigados aspectos da experimentação com elementos da Commediadell'Arte com os jovens do assentamento, sendo os seguintes elementos escolhidos para orientar a investigação: a construção corporal dos tipos do gênero, a confecção de máscaras e a elaboração de roteiro. Após a aplicação da pesquisa-ação, foi verificado que tais elementos articulam-se e compõem, cada um com sua respectiva especificidade, o trabalho geral em torno das máscaras dell'Arte. A experimentação objetivou explicitar a apropriação e transformações realizadas pelos sujeitos participantes a partir de suas identificações culturais às máscaras trabalhadas. Para a aplicação da experimentação, foi realizada pesquisa teórica em torno de temas relacionados à Commediadell'Arte, como o contexto histórico social e artístico de seu período, a cultura popular na Idade Média e no Renascimento, a perspectiva do grotesco nesses períodos e a função social do riso e de alguns de seus mecanismos de produção. Os resultados foram analisados pela perspectiva do pesquisador a partir das improvisações, do processo de trabalho, dos depoimentos e avaliações dos jovens e apontaram principalmente para a potencialidade de trabalho com a atualização de alguns elementos da Commediadell' Arte a partir da imaginação e do contexto específico dos sujeitos participantes.

Área de Conhecimento: ARTES

Áreas Afins: TEATRO

Linha de Pesquisa: DRAMATURGIA, HISTÓRIA E RECEPÇÃO 
8. THELMA LOPES CARLOS GARDAIR. INTEGRANDO A PERCEPÇÃO DE ESTUDANTES À CRIAÇÃO DE PEÇA TEATRAL: UMA ALTERNATIVA DE EDUCAÇÃO CIENTÍFICA EM DIÁLOGO COM AS ARTES, 2012, MESTRADO ACADÊMICO EmENSINO EM BIOCIÊNCIAS E SAÚDE

\author{
Instituição: FUNDAÇÃO OSWALDO CRUZ, RIO DE JANEIRO.
}

Palavras-chave: Ciência \& teatro; Estudantes de ensino básico; Percepção de ciência \& arte; Ensino de ciências; Shakespeare \& Galileu

\title{
Resumo:
}

O presente estudo aborda aproximações entre ciências e teatros, suas possíveis relações com a educação em ciências, e o papel potencializador da linguagem teatral na construção de imagens menos estereotipadas do cientista e artista. A pesquisa também explora o estímulo ao debate sobre temas científicos, articulado a outros saberes, voltado a estudantes do ensino fundamental e médio. Dentre os principais objetivos desta tese destacam-se: a) Análise das percepções dos sujeitos pesquisados acerca da imagem do cientista, artista e sobre noções de artes e ciências; b) Desenvolvimento de peça teatral, baseada em dados obtidos por meio de questionários e pesquisa histórica, que consista em estratégia educativa voltada para discussão sobre ciências articulada às artes; c) Análise dos efeitos da peça junto aos participantes da pesquisa. Para tanto, 226 estudantes responderam questionário, categorizados em três grupos, a saber: jovens artistas, jovens cientistas e alunos de escolas públicas. O grupo por nós chamado de "jovens cientistas" é composto por estudantes da "Escola Politécnica de Saúde Joaquim Venâncio" (EPSJV) e alunos que integram o "Programa de Vocação Científica" (PROVOC). Na presente pesquisa o grupo de "jovens artistas" é composto por estudantes que participam de atividades relacionadas à linguagem teatral em duas instituições, a saber: "Casa das Arte de Laranjeiras" (CAL) e "Colégio Salesiano Santa Rosa". Um terceiro grupo integrou nosso estudo e compôs-se de estudantes que não estavam vinculados a instituições educativas, programas ou atividades voltadas para o desenvolvimento de aptidões artísticas ou científicas. Este grupo foi formado por alunos da "Escola Estadual Amaro Cavalcanti" e do "Collège Jean Jaures". Ambas as instituições são públicas. A primeira localiza-se no bairro do Largo do Machado, no Rio de Janeiro, e a segunda na cidade de Montreuil, na França. As respostas foram interpretadas à luz do método de "análise de conteúdo", sistematizado por Laurence Bardin (1978). Os fundamentos para a escrita da peça foram, principalmente, pesquisa histórica e dados obtidos a partir dos 226 questionários. A trama da peça "Toda menina é uma rainha" consiste na aventura de dois adolescentes ávidos por conhecer o mundo e a si mesmos, que ao remexerem em antigos livros, transportam-se para o século XVI, em 1582, na Inglaterra, onde vivenciam o cotidiano da época, tornam-se amigos da rainha e presenciam um inusitado encontro entre Galileu Galilei e William Shakespeare. Como estudo piloto dos efeitos da peça junto ao público alvo da pesquisa, foram realizados dois encontros nos quais desenvolveu-se jogos teatrais, exercícios de aproximação aos temas explorados na peça e preenchimento de questionários. Culminando com a leitura dramatizada da peça, os referidos encontros possibilitaram a identificação de qualidades e limites do texto como ponto de partida para a discussão sobre ciências.

Área do conhecimento: ENSINO EM BIOCIÊNCIAS E SAÚDE 
9. VANESSA BIANCASGALHEIRA. VIAS DE EXPRESSÃO EM ADOLESCER: ANÁLISE DA OFICINA DE TEATRO COM ADOLESCENTES E JOVENS DO COMPLEXO MORUMBI EM UBERLÂNDIA-MG' 01/03/2012 179 f. MESTRADO ACADÊMICO em ARTES

Instituição de Ensino: UNIVERSIDADE FEDERAL DE UBERLÂNDIA

Biblioteca Depositária: SISBI - SISTEMAS DE BIBLIOTECAS DA UNI. FED. DE UBERLÂNDIA

Palavras-chave: Teatro; Jovens; Improvisação, Periferia; Narrativas

Resumo: A pesquisa reflete sobre os cinco anos de atividades da oficina de teatro com jovens em comunidades periféricas na cidade de Uberlândia. Trataremos de assuntos como exclusão e violência, fenômenos revelados pelos sujeitos nas improvisações e que se tornaram narrativas. Realizamos ações de fazer,apreciar, criar e contextualizar, fundamentada nos aspectos populares da educação. O trabalho caracterizase como ação cultural entremeada as pessoalidades para criação dramatúrgica e cênica no trânsito entre periferia e centro, possibilitando a conquista da autonomia dos fazeres.

\footnotetext{
Área de Conhecimento: ARTES

Áreas Afins: ARTES

Linha de Pesquisa: Práticas e processos em Artes:
} 
QUADRO 3 - Número total de dissertações e teses defendidas na USP e número total de Dissertações e teses defendidas na USP abordando temas ou questões sobre o(s) jovem(ns) ou juventude, entre 2007-2014

Ano de
defesa

defesa Número de
dissertações e
teses defendidas na USP entre 2007-2014

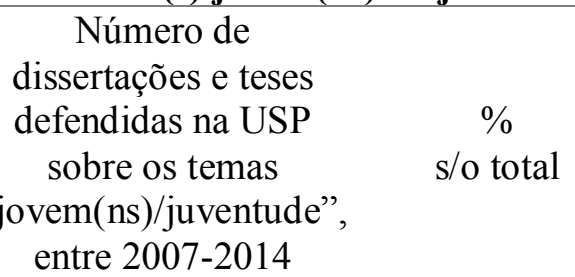

Número de

dissertações e

teses abordando

os temas

$\operatorname{jovem}(\mathrm{ns}) /$

juventude,

produzidas na

área de Educação

\begin{tabular}{ccccc}
\hline 2007 & 4.382 & 17 & 0,38 & 5 \\
\hline 2008 & 4.740 & 23 & 0,48 & 8 \\
\hline 2009 & 5.150 & 18 & 0,34 & 8 \\
\hline 2010 & 5.149 & 24 & 0,46 & 6 \\
\hline 2011 & 5.108 & 15 & 0,26 & 5 \\
\hline 2012 & 5.561 & 16 & 0,28 & 5 \\
\hline 2013 & 5.369 & 18 & 0,33 & $6(*)$ \\
\hline 2014 & 2.974 & 15 & 0,50 & 4 \\
\hline Total & $\mathbf{3 8 . 4 3 3}$ & $\mathbf{1 4 6}$ & $\mathbf{0 , 3 7}$ & $\mathbf{4 7}$ \\
\hline
\end{tabular}

\section{Data-base: setembro, 2014}

(*) A partir de 2013, trabalhos desenvolvidos na Faculdade de Educação - FEUSP e na

Faculdade de Filosofia, Ciências e Letras de Ribeirão Preto - FFCLRP 
QUADRO 4: Caracterização dos jovens que contribuíram com o estudo, segundo características sócio demográficas, socioculturais e ocupacionais, 2015.

\begin{tabular}{|c|c|c|c|c|c|c|c|c|}
\hline Nome & Idade & $\begin{array}{l}\text { Perten. } \\
\text { Etnico-racial }\end{array}$ & $\begin{array}{l}\text { Estado } \\
\text { civil }\end{array}$ & $\begin{array}{l}\text { Cidade de } \\
\text { moradia }\end{array}$ & Escolaridade atingida & $\begin{array}{l}\text { Experiência(s)de formação } \\
\text { artístico culturais antes do ingresso no } \\
\text { IRC }\end{array}$ & Trabalhava? & $\begin{array}{l}\text { Ocupação da mãe e do } \\
\text { pai }\end{array}$ \\
\hline Andrei & 17 & Branco & Solteiro & Cravinhos & Ensino médio completo & $\begin{array}{l}\text { Sim.Teatro-Iniciativa do Executivo } \\
\text { Municipal }\end{array}$ & não & $\begin{array}{l}\text { Mãe - Empregada } \\
\text { doméstica } \\
\text { Pai - Mecânico }\end{array}$ \\
\hline Vânia & 18 & Branca & Solteira & Ribeirão Preto & Ensino médio completo & $\begin{array}{l}\text { Sim - escola de teatro } \\
\text { Escola básica }\end{array}$ & não & $\begin{array}{l}\text { Mãe - Auxiliar de } \\
\text { laboratório } \\
\text { Pai - não soube informar }\end{array}$ \\
\hline Igor & 18 & Branco & Solteiro & Ribeirão Preto & $\begin{array}{l}\text { Ensino Superior } \\
\text { (Cursando) }\end{array}$ & $\begin{array}{l}\text { Sim - grupo teatral amador e na Igreja } \\
\text { Evangélica }\end{array}$ & $\begin{array}{l}\text { Sim.Eventual } \\
\text { Designer }\end{array}$ & $\begin{array}{l}\text { Mãe - Pedagoga } \\
\text { Pai - Policial Militar }\end{array}$ \\
\hline Natália & 18 & Branca & Solteira & Ribeirão Preto & $\begin{array}{l}\text { Ensino médio } \\
\text { completo }\end{array}$ & $\begin{array}{l}\text { Sim - Escola de Violão e } \\
\text { Canto Coral em Igreja Católica }\end{array}$ & Sim. Eventual & $\begin{array}{l}\text { Mãe - trabalhadora } \\
\text { autônoma } \\
\text { Pai - Pedreiro }\end{array}$ \\
\hline Nádia & 27 & Branca & Solteira & Ribeirão Preto & $\begin{array}{l}\text { Ensino Superior } \\
\text { completo }\end{array}$ & $\begin{array}{l}\text { Sim - escola de teatro, Escola de ensino } \\
\text { fundamental }\end{array}$ & $\begin{array}{l}\text { Empresa de } \\
\text { Seguros }\end{array}$ & $\begin{array}{l}\text { Mãe - não informado } \\
\text { Pai -não informado }\end{array}$ \\
\hline Nicolas & 17 & Parda & Solteiro & Ribeirão Preto & Ensino médio completo & $\begin{array}{l}\text { Sim - Igreja Católica e } \\
\text { Escola de teatro }\end{array}$ & $\begin{array}{l}\text { Sim, eventual.Feira } \\
\text { livre. }\end{array}$ & $\begin{array}{l}\text { Mãe - Faxineira } \\
\text { Pai - Feirante e pedreiro }\end{array}$ \\
\hline Marina & 29 & Branca & Casada & Ribeirão Preto & $\begin{array}{l}\text { Ensino Superior } \\
\text { completo }\end{array}$ & $\begin{array}{l}\text { Sim. Escola de balé, Igreja Evangélica: } \\
\text { dança e canto }\end{array}$ & $\begin{array}{l}\text { Sim-Professora } \\
\text { concursada }\end{array}$ & $\begin{array}{l}\text { Mãe - não informado } \\
\text { Pai -não informado }\end{array}$ \\
\hline Ivan & 17 & Negro & Solteiro & Serra Azul & $\begin{array}{l}\text { Cursando o } 2^{\circ} \text { do ens. } \\
\text { médio }\end{array}$ & Sim.Iniciativa do Executivo Municipal & $\begin{array}{l}\text { Sim-Educador } \\
\text { Informática }\end{array}$ & $\begin{array}{l}\text { Mãe - não informado } \\
\text { Pai - não informado }\end{array}$ \\
\hline Alexander & 19 & Negro & Solteiro & Ribeirão Preto & Ensino médio completo & $\begin{array}{l}\text { Sim.Igreja Evangélica - dança, teatro } \\
\text { Balé }\end{array}$ & $\begin{array}{l}\text { Sim.Atendente em } \\
\text { Pastelaria }\end{array}$ & $\begin{array}{l}\text { Mãe - Falecida } \\
\text { Pai - não informado }\end{array}$ \\
\hline Sofia & 21 & Branca & Solteira & Ribeirão Preto & $\begin{array}{l}\text { Ensino Superior } \\
\text { (Cursando) }\end{array}$ & $\begin{array}{l}\text { Sim.Antes da Escola básica: música e } \\
\text { dança. Em paralelo à escola básica: teatro }\end{array}$ & Não & $\begin{array}{l}\text { Mãe - Professora } \\
\text { Pai - Farmacêutico }\end{array}$ \\
\hline Olga & 20 & Branca & Solteira & $\begin{array}{l}\text { Ribeirão Preto } \\
\text { (migrante) }\end{array}$ & Ensino médio completo & $\begin{array}{l}\text { Sim.Muito efêmera, em Igreja Católica, } \\
\text { encenação }\end{array}$ & $\begin{array}{l}\text { Sim. Atendente } \\
\text { Em Imobiliária }\end{array}$ & $\begin{array}{l}\text { Mãe - Funcionária } \\
\text { empresa pública } \\
\text { Pai - ocupação no setor } \\
\text { da Aviação }\end{array}$ \\
\hline Lucas & 17 & Branco & Solteiro & Ribeirão Preto & $\begin{array}{l}\text { Ingressando no } \\
\text { Ensino Superior }\end{array}$ & $\begin{array}{l}\text { Sim - Teatro no Ensino Fundamental e } \\
\text { SESI-RP }\end{array}$ & Não & $\begin{array}{l}\text { Mãe - Professora } \\
\text { universitária } \\
\text { Pai - Professor } \\
\text { universitário }\end{array}$ \\
\hline
\end{tabular}

Fonte: Entrevistas realizadas nas atividades de campo do Projeto de Pesquisa. 


\section{ENTREVISTA}

Vânia ${ }^{47}-18$ anos

Pesquisador- Quais os motivos da escolha da oficina de teatro do IRC nesse momento de sua vida?

Vânia- É que eu já fazia teatro há alguns anos, então o IRC serviu mais pra me... levar um pouco mais, artisticamente falando, um pouco mais de maturidade artística. Eu vi isso lá... Eu vi um lugar um pouco mais... bem diferente do que eu to habituada hoje. Então acho que agora é isso.

P- Você falou que fez antes, como foi?

V- Eu fiz desde 2011.

P- Você tinha quantos anos?

V- Eu tinha 14.

P- Você fez onde, como era essa experiência anterior?

$\mathrm{V}$ - Eu fiz no [escola de teatro ${ }^{48}$ ], mas é muito diferente, assim até porque questão de diretor que te orienta né. E meu primeiro ano lá foi bem... bem - que palavra que eu uso- foi bem simples. Não foi nada, bem iniciação teatral.

P- E como é que é lá, é pago?

V-Lá é pago, mensalmente, bonitinho (risos).

P- E você fez quanto tempo de [escola de teatro]?

V- Fiz 3 anos.

P- E quando eu pergunto pra você a escolha do IRC, é porque você já fazia teatro. Mas como você começou a fazer teatro?

$\mathrm{V}$ - Parece que foi uma coisa que eu buscava, eu buscava alguma coisa assim em mim, fosse... acho que me tirasse dessa coisa, dessa rotina. Que exercesse alguma coisa que pudesse ampliar meus horizontes (risos).

P- Você fez alguma coisa na área cultural antes. Alguma outra atividade?

$\mathrm{V}$ - Eu tentei musica e artesanato, mas nada deu certo (risos), mas desde pequena eu tive mais voltada pra essa coisa artística.

$\mathrm{P}$ - Mas você sabe de onde vem isso?

V- Não.

\footnotetext{
${ }^{47}$ Todos os nomes dos jovens e educadores são fictícios.

${ }^{48}$ Escola de teatro na cidade, nome preservado.
} 
P- Na sua família tem alguém envolvido em alguma questão artística?

V- Ninguém, Ninguém. A única pessoa que na verdade me dava esse apoio era o meu avô né, mas depois que ele faleceu, eu tive essa coisa. Acho que talvez é por isso que eu procurei o teatro, antes eu ainda tava sendo incentivada, depois parou eu pensei "Opa! Vamo por minha conta né?"

P- Mas o teu avô ele mexia com alguma coisa, algum instrumento, alguma outra...

V- Ele só me incentivava, na minha família não tem artistas. (risos)

P- Outra pergunta... Quais a contribuições dessa formação em teatro pra sua educação hoje?

V- Como pessoa ou...

P- Como que você acha que o teatro contribui para sua educação?

$\mathrm{V}$ - Eu sinto diferença, quando eu falo quando eu era do [escola de teatro] e no IRC. No IRC parece eles te abrem pra um caminhos diferentes, coisa que eu não fazia antes eu acabei tendo essa coisa de querer fazer... por exemplo, eu não lia muito, eu não buscava conhecimento, assim. Eu lembro que quando fui assistir "Antiperipléia" eu não tinha noção do Guimarães Rosa, eu não tinha noção do Guimarães Rosa e eu amo Guimarães Rosa hoje. Então nessa questão, assim me mudou nessa parte conhecimento, hoje eu busco mais saber, mais conhecer as coisas do que antes, eu ignorava muito isso.

P- Quando você fala conhecimento, na escola, fora...o que você que dizer?

V- Acho no geral, eu acho que a escola... eu falo que eu comecei a aprender de verdade quando eu entrei no teatro. Porque na escola é muito aquela coisa que... o professor dita... vai jogando né? Não é nada que te instiga a aprender, eu acho que a arte tem esse poder né de te fazer querer aprender, acho que o teatro tem essa coisa da educação da pré-escola, que a criança fica vidrada, porque a criança tá muito mais interessada, por exemplo, naquela aula que leva uma borboleta, um casulo. (risos). A criança fica muito mais vidrada em conhecer isso do que saber, contar, do que saber matemática, qual a hipotenusa do... (risos). É muito mais interessante eu comecei a sentir isso, quando comecei a ser instigada pelo pessoal do teatro e comecei a levar isso pra vida: "Nossa, putz! Guimarães Rosa que legal”, aí fiquei encantada e isso me mudou muito como pessoa, o hábito da leitura. É uma coisa que antes eu não tinha.

P- Você tá estudando agora?

V- Não.

P- Você estudou em que escola?

V- Eu estudei... Todas? (risos)

P- Vamo lá! (risos) 
V- No pré eu estudei no Sebastião de Aguiar é uma escola perto da minha casa, bem do lado. Era muito boa até certa época... e quando eu tava na 5 série eu fui pro Gasparini, que era uma escola que eu também achava muito boa, mas parece que as escolas que eu fui entrando foi piorando (risos) não sei porque, não é minha culpa! (risos). E eu fui no Gasparini na época na intenção de ter uma educação melhor, na época tinha essa coisa de “o Gasparini” era difícil conseguir vaga lá. Logo depois parece que foi piorando, eu fiquei lá até terminar, lá não tem colegial e no colegial eu fui pro Tomas Alberto e terminei lá

P- E essas escolas são públicas?

V- São publicas, desde o começo, desde que eu me entendo por gente eu sou de escola pública. Sempre.

P- Sim, e dentro da escola você achou algo relacionado com arte? Fez peça na escola?

V- Quando eu comecei a fazer teatro, alguns professores, são poucos os que não têm essa didática de ficar jogando coisa pro aluno aprender, aprender e não absorver nada. Dos poucos professores que eu tive quando eles souberam que eu fazia teatro eles começaram a querer que... teve um professor que no Gasparini que montou com a gente uma pecinha, dos Deuses (riso) bem podrinha, mas foi (risos). No colegial também eu tive uma professora que pediu ajuda minha pra montar uma semana cultural então já tinha no Tomas Alberto eu sentia um pouco mais isso da arte envolvida, ele levavam um pouco mais a serio. Alguns, não. Tem sempre os professores que não ligam.

P- Por que os professores pediam ajuda para você?

V- Talvez porque eu era a única da sala que ligava pra isso e a única que falava. Eu ficava “ah!”(suspiro). E meus amigos sabiam que eu fazia teatro, então tinha aquela comunicação era muito interessada.

P- Isso começou a acontecer quando você começou a fazer teatro?

V-Sim.

P- Tanto no [escola de teatro] quanto no Ribeirão em Cena?

$\mathrm{V}$ - No IRC mais.

P- Então você fazia o IRC, e as pessoas olhavam pra você como uma pessoa que fazia teatro e eles te pediam ajuda?

V- Tipo isso, também porque eu tinha bastante interesse nessa área, eu nunca me interessei por matemática por exemplo. Então quando tinha algum assunto relacionado com literatura, com artes em si eu era mais, eu era a única, não a única porque tem um amigo que desenha e que tinha essa coisa.

P- Você desenha? 
V- Não (risos). Quem sabe um dia...

P- Você falou uma coisa que eu achei interessante, você comparou a escola com o IRC. Quais as diferenças?

$\mathrm{V}$ - As diferenças... O IRC me lembrava a pré-escola quando eu comecei a fazer, é muito mais interessante eu aprender coisas que realmente importam, do que tá numa escola que eu tô aprendendo coisas assim jogadas, que não vai me levar... daqui há alguns anos eu não vou lembrar de nada que eu aprendi, uma coisa ou outra...

P- Mas isso tá nos professores, na sala...

V- É que perdi, a pergunta tô meio..

P- Eu perguntei sobre as contribuições para sua educação, aí você fez um comparativo com a escola... com a pré-escola, então tinha algo na pré-escola que depois se perdeu o que esse algo?

V- Essa, coisa...

P- Sem medo de errar... diz aí...

$\mathrm{V}$ - Eu tenho lido Rubens Alves, ele fala que as coisas mais simples, menos importantes da vida são as que causam mais curiosidade, numa criança. E ele fala que nossa mente é como um escorredor de macarrão: quando você joga o macarrão que fica, a água vai embora. O que a gente aprende é o que fica. Então tudo que a gente aprende pro vestibular é tudo jogado. $\mathrm{O}$ que a gente gosta tudo o que é incentivado, o que causa e desperta um interesse maior é o que fica. Não adianta ficar aprendendo, aprendendo, aprendendo sendo que daqui há alguns anos a gente esquece tudo. Acho que é só memorizar... Você só memoriza, o vestibular mesmo: você vai estudar, estudar, estudar e vai memorizar pra fazer a prova e depois você vai esquecer tudo. O que você aprende mesmo você leva pro resto da vida.

P- Você acha que a escola poderia ser mais assim?

V- Acredito. Sim.

P- Então, vendo assim as contribuições: você começou ler mais, isso? E tem uma outra coisa que você falou que eu não entendi muito bem, você disse algo sobre busca...

V- Talvez por se encontrar no... assim o que você quer da sua vida, tinha muito isso no começo quando eu comecei no IRC, era isso sabe? Será que eu devo continuar no caminho artístico, será que isso é uma opção válida, ou eu devo fazer uma coisa que me de dinheiro pra me manter. Lembro que eu queria fazer artes cênicas e tinha essa coisa do será que sim, será que não (ri). Hoje mudou muito minha opinião em relação a isso, acho muita coisa que você faz ajuda, tudo agrega né, no seu ser... então, hoje eu penso diferente em relação a isso (risos). Eu perdi um pouco a pergunta. 
P- Não, tá no caminho, continua! Então há contribuições para o âmbito artístico?

V-Sim.

P- Elas vão pra outro caminho, se a gente pensar a educação num modo mais amplo, acho que quando eu perguntei da escola eu... acho que você delimitou a conversa em relação a escola. Pra educação... pra como você se educa por exemplo...O teatro colabora com mais alguma coisa?

V-Sim, muita coisa!

P- O que você pode me dizer sobre isso, dar exemplos?

V- O teatro parece que... na questão da gente pensar, para e pensa no que você tá fazendo... no cotidiano, isso pra mim foi importante. $\mathrm{Na}$ arte tem essa coisa de você ouvir melhor, prestar atenção, isso que contribui, ter mais atenção. É difícil porque eu sou muito acelerada, então é difícil pra mim dar uma pausa e dizer "Calma Vânia, fala devagar!”. A gente tá aprendendo até com o [educador] nessa peça, " respira, tudo tem seu tempo" (riso). Tem que ter um certo equilíbrio das coisas. Acho que enquanto ser humano me ajudou muito questão do ser. A disciplina que eles, eles tem uma disciplina, como [educador] falou esses dias, não é só a intenção de fazer peças é pra formar atores e seres humanos também. Tem muita gente que me fala, que tem um ponto de vista diferente de quando entrou no IRC, que voltou a estudar, que voltou.

P- Tem gente que voltou a estudar?

V- Tem sim, tem gente que me falou que se sentiu incentivada a voltar a estudar, essa vontade de querer aprender, diferente da escola que tinha muitos professores bons até que não incentivavam essa curiosidade “ah!”. Curiosidade! é a palavra que eu tava procurando! (risos) Achei!

P- Era essa palavra, você acha que falta curiosidade na escola.

V-Sim, falta.

P- E quando você fala, essa questão do ser humano, o que você quer dizer com isso? O que o teatro ajuda em ser humano?

V- Eu acho que ao mesmo tempo, que eu não... eu tenho que esta me importando com o outro. Muitas pessoas da minha turma mesmo... (hesita).

P- Pode falar o que quiser se quiser falar algum nome eu vou trocar, fica tranquila...

V- (rindo) Então muitas pessoas da minha turma mesmo chegaram lá com outra... com postura assim em relação ao outro... pessoas assim bem, arrogantes, falei ! (risos). Arrogantes, falar palavra exata, e hoje convivem bem com todas as pessoas. Eu lembro da primeira quebra, a gente fez uma cena com as pessoas que a gente menos conhecia, e é engraçado que 
tinha esse preconceito, muitas pessoas tinha preconceito um com o outro então foi difícil quebrar isso, tem uma pessoa que mudou muito, era o que mais olhava. Tinha essa questão de "aonde quer chegar", ali dentro. Eu sinto que isso foi muito quebrado. Coisa que eu não via no [escola de teatro] antes, que lá tem uma coisa um pouco diferente que é isso, de um ser mais que o outro. No IRC foi mais quebrado isso, ainda tem, e tem incentivo por alguns professores, normal, mas hoje eu sinto que do que a gente era e onde agente tá tudo no mesmo nível, ninguém é mais e ninguém é menos

P- Então você acha que isso afeta as relações humanas?

V-Sim.

P- E quando você fala em relação ao outro, você diz no sentido de conviver? De estar com o outro...

V- Tanto em convivência quanto em cena eu preciso do outro. Em cena eu preciso que... sabe aquela coisa do "eu preciso de você", não adianta eu quebrar a perna do outro, jogando uma coisa que ele não sabe, que... jogar uma bola sabendo que ele não tá vendo que eu vou jogar... Ele não viu. Eu tenho que estabelecer esse contato como outro, pra que ele possa pegar do outro lado, não deixar cair. Na peça é isso também.

P- Então as pessoas eram muito...

V-Sim extremamente

P- Extremamente o que?

V- Tentar achar a palavra certa, tinha essa diferença (imitando outra voz), "eu sou mais, eu sou menos, eu venho de uma companhia, eu venho de uma escola de teatro". Tinha aquela, acho que acho que até eu mesma, não tem como não... tinha aquela pessoa que nunca fez teatro na vida então era diferente, a gente teve que lidar com várias personalidades, pessoas que vieram de lugares diferentes, pessoas com ideias diferentes. É difícil, porque você convive com isso na escola, por exemplo, numa sala de aula é normal, tudo ali na multidão. Mas quando você é colocado dentro de uma sala, ali todo mundo, tem um conflito. Isso ajuda, é uma coisa assim, mas depois acalma, depois consegue com muito trabalho acho, dá trabalho, mas fica todo mundo na mesma energia.

P- E o que mudou em você?

$\mathrm{V}$ - Eu acho que isso, eu era também, eu vim eu já faço teatro, eu sei de tudo eu sei mais que todo mundo ali...

P- Você entrou assim? 
V- Entrei, e muita gente que entrou de fora tinha esse pensamento também. Quem já era de uma companhia era mais que eu, então já era uma coisa bem "sociedade"(rindo). Aquela coisa, que a gente não percebe. (risos)

P- Você baixou a bola...

$\mathrm{V}$ - Sim, fiquei mais humilde. (risos) Eu acho que isso me tornou mais humana.

P- Você acha que isso te ajudou nos outros ambientes onde você convive, alguém sentiu diferença, dizem que te mudou em algum sentido, as pessoas que vivem com você em outro lugar?

V- Muitas pessoas falaram que me mudou né, no primeiro mês, nossa Vânia você tá diferente, o convívio melhorou, eu deixei de dar importância a algumas coisas que não tinha importância. A ter um foco, não dispersar com picuinhas, que não vão me levar a nada. Então eu me tornei uma pessoa mais calma, eu era muito estressada!

P- É?

V- É. (risos) Então isso me ajudou, a levar menos a sério, mas ao mesmo tempo mais sério por causa da disciplina. A focar, isso... ter um foco.

P- Em que ambiente isso?

V- Tanto escolar quanto familiar, mas o familiar ainda tenho o que mudar. E o convívio diário.

P- E no escolar, alguém falou isso, quem?

V- Perceberam e falaram, nossa Vânia, amigos, professores, chegaram a falar.

P- Algum professor te falou o que por exemplo?

V-Sim eu tinha uma professora de português que dava parte de literatura, e por coincidência é mãe de uma aluna do IRC à noite, que eu fiquei sabendo bem depois. Ela viu que eu comecei a ter mais interesse por saber de livros, por saber de... pela informação sabe? Pelo saber eu tive mais curiosidade até em biologia, (risos). Então, isso, melhorou em mim, parece vendo até aqui, aqui outra Vânia (risos). Mudou muito, então eles perceberam, meu interesse. Meus amigos perceberam também isso.

P- Amigos da escola?

V- Amigos da escola.

P- Você trabalha?

V- Não.

P- Você já trabalhou?

V- Não. 
P- Nunca trabalhou, senão eu ia perguntar como seria (risos). E durante o IRC você faz ou fazia alguma outra atividade, algum curso?

V- Tô tentando lembrar... nada.

P- E antes, você fez alguma coisa, de arte?

V- Nada, eu tentei música, mas foi por pouco tempo, particular assim.

P- Mas você tentou o que, tocar algum instrumento?

V- Violão, parei. Talvez é uma postura que hoje eu não teria, da desistência.

P- Vou te fazer outra pergunta: Você vê alguma relação entre os conteúdos e os exercícios que você vivencia no IRC, com o seu cotidiano?

V-Sim.

P- E você consegue exemplificar?

V- Então... sim por exemplo, eu acho que o exercício da corda, que a gente tem que pular ajuda no dia a dia, e meio tosco o que vou falar. Você tá na rua, você vai desviando, porque ninguém te olha, eu sinto essa falta de contato. Eu comecei a ter esse contato maior, eu tô na rua mas eu sei que se alguém for me trombar eu vou desviar, é uma atenção maior. Sei lá pessoa cheia de sacola correndo, e mesmo que ela não veja você, parece que eu vou notar e vou desviar, porque eu percebo a pessoa. Eu fiz uma oficina de... viewpoints, e eu me vi na rua, assim.

P- Você consegue explicar mais ou menos?

V- Viewpoints, pontos de vista... é difícil explicar, mas.. É uma oficina de jogos, tinha muito isso de "estar com o outro". Você faz uns exercícios de escuta, você escolhe um ponto e você vai andando, tem um trajeto, tem que saber quando o outro termina, tem que ter a escuta, perceber a pessoa quanto termina o trajeto, vira uma máquina... É uma escuta, percepção.

P- Escuta é percepção?

$\mathrm{V}$ - É isso.

P- Então isso reverbera no seu cotidiano, no seu olhar. Como?

V- Não entendi.

P- Você percebe você sai de casa e olha diferente, é isso?

V-Sim, Eu consigo olhar pra fora hoje, antes era muito interno. Uma coisa, eu tô andando e não tô percebendo onde que eu tô (risos). Já aconteceu um caso que eu comprei um negócio e eu não sabia onde tava, de tão avoada que eu estava. Eu não estava presente. Até hoje eu quero saber onde foi parar! (risos). Sem brincadeira, eu me pergunto onde que está. Nossa como que eu era desatenta.

P- E o exercício da corda, que você falou? 
V- Parece que me da atenção, é dinâmica assim sabe.

P- Explica como é...

V- Aquele joguinho clássico de pular corda, mas tem uma atenção a mais, porque você tem que prestar atenção no outro, porque é em fila e você tem que entrar no último pulo do outro. Você tem que manter a atenção no outro e na hora que você tem que entrar pra manter essa energia né, pra você entrar na hora certa. Ai depois vai voltando, depois "dois", ai pula dois, "um", ai pula um, e depois chega no mais "hard" que você tem que passar sem pular, prestar atenção em você, no outro e na corda pra não bater em você, e tomar cuidado pra não machucar . Então ajuda pra manter atento e dinâmico.

P- E essa questão de cuidar do corpo. E tem algum outro?

V- Eu não vou lembrar... agora. Depois eu lembro e vou dizer ai! Que raiva (risos)

P- Tudo bem... outra pergunta: Que importância que essa formação traz pro seus projeto do futuro?

$\mathrm{V}$ - Eu conheço gente que resolveu fazer faculdade de artes cênicas e tá mais preparado, talvez não tivesse se não tivesse feito. Então o IRC prepara, então, o Lucas, tá indo pra UNESP, Artes Dramáticas e ele tá preparado, talvez se ele não fizesse... ele não tivesse entrado. Conheço gente que fez faculdade e diz... o IRC da formação. Tanto é que o [educador] falou do pessoal de Bogotá, que veio aqui e disse que quando veio pra cá, achava que era uma escolinha de teatro mas não, tem uma disciplina rígida né? Em formação de atores, e isso eu vou levar pra minha vida. Mesmo que eu resolva fazer outra coisa, me ajudou, mesmo que às vezes eu tenha algumas reclamaçõezinhas pessoais de lá, mas vendo por esse lado eu não tenho como reclamar da forma que me ensinaram, do que foi passado pra mim. Que bom que eu tenho professores tão bons, como o [educador]

P- Pra ficar claro essa coisa que você falou de Bogotá. Como foi isso?

V- Eu não participei, mas é um pessoal que tem uma pesquisa sobre os orixás e o corpo, pesquisa corporal e vieram pra cá. E quando viram, disseram que pensaram numa escolinha de teatro, pra amador, e é mas tem tanta disciplina tão rígida e um trabalho tão preparado.

P- Mas você pretende estudar artes cênicas, você disse que o IRC pode te ajudar.

V- No momento não. Eu pretendo um dia, mas no momento não.

P- Como assim?

V- Ao mesmo tempo eu tenho lido muito e talvez eu... eu prefiro, talvez seja bom, mas eu prefiro fazer agora pedagogia. Então eu acho interessante essa coisa de trabalhar com criança, mas eu não descarto a possibilidade de trabalhar com teatro e com criança. Eu tenho lido muito Viola (Spolin) é bem bacana e acho que jogos teatrais é uma coisa que tanto pra mim, 
quanto pra criança, pra todos, mas pra criança principalmente por que tá na fase de formação e tem escola que é muito "gaiola" na mente da criança, que prende a criança e criança é pássaro. Tem que conduzir o vôo e não prender. Eu acho que o teatro permite isso, pelo que eu vi e aprendi eu senti muito essa vontade.

P- E quando você fala que você quer fazer pedagogia e o mesmo tempo quer ser atriz... me explica melhor isso, qual é teu plano?

V- Meu plano era esse: fazer pedagogia agora, em questão de uma pesquisa pessoal, pra transferir o que eu sei pra criança ter oportunidade de aprender o que eu aprendi.

P- Mas você fazendo pedagogia você vai ensinar pra criança o teatro? E isso que estou tentando entender... Você disse que o IRC seria importante pra que você fosse fazer artes cênicas, no caso você não quer fazer artes cênicas?

V- Tenho vontade, mas no momento a pedagogia seria um ponto de partida.

P- Por que hoje você não faria hoje?

V- Agora não, não me sinto preparada, eu ainda sinto que tenho que aprender muito mais, pra eu falar, assim pessoal mesmo, pra eu dizer agora eu não tenho mais tantas dúvidas, dúvida a gente sempre vai ter, eu tô mais tranquila, sem questões que "eu tenho que fazer alguma coisa pra me manter”, infelizmente tem isso também, então a pedagogia vai dar uma...

P- Então você pensa em fazer pedagogia pra...

V- Pra primeiro me estabilizar.

P- É uma estratégia sua fazer pedagogia pra depois fazer teatro.

V-Sim.

P- E você acredita que pra você trabalhar como atriz precisa ter essa formação superior em artes cênicas?

V- Não.

P- E você descarta trabalhar com teatro agora?

V- Não, peraí...

P- Você tem vontade de terminar o IRC, e começar uma a trabalhar numa peça por exemplo?

V-Sim, entendi, sim agora.

P- Tentando resumir, a importância da formação no IRC é que você pode vir a fazer artes cênicas depois, e você pode terminar o IRC trabalhar com teatro em algum momento?

V-Sim, mas não deixar pra trás o que aprende, acho que o ator tem que tá sempre, continuar aprendendo. Não adianta parar, daqui a pouco eu esqueço muita coisa que aprendi. Eu tenho esse medo, exemplo acaba o IRC esse mês, o que vai acontecerem breve, mas eu quero continuar aprendendo. Eu quero continuar no meio teatral, pra cada vez mais absorver isso. 
P- E como você vai fazer isso, você tem alguns planos?

V- Talvez investir em oficinas né. Talvez continuar aqui, eu não sei tá meio obscuro ainda porque, tá acabando em meses. (rindo) Tá triste pra mim! Oficinas eu sempre faço, nas férias. Talvez investir nisso mais.

P- Então teatro é uma coisa que você pretende investir pra sua vida, mas se você tiver uma outra profissão também?

V- Sim, é isso, não descarto a possibilidade unificando, juntando.

P- Levando as duas coisas?

V-Sim levando as duas.

P- E qual foi o primeiro contato com o teatro?

V- Primeiro que estive ou que eu vi?

P- A primeira coisa que você lembra de teatro, vendo ou fazendo.

V- Primeiro contato que eu tive foi um monologo, foi bem, bem... Era uma aula experimental

no [escola de teatro] e eu nunca tinha feito nada disso. Eu nunca tinha pegado um texto pra interpretar, sair da leitura.

P- Você tá falando fazer, mas antes, mais jovem você viu alguma coisa?

V- Antes, você não tinha visto nada.

P-Sério? Você já chegou direito fazendo.

V- Me deu uma coisa de testar teatro, eu tive essa ideia de testar teatro, dança... acho que apareceu essa ideia, uma lâmpada na minha cabeça. A não ser aquelas pecinhas de escola, tipo de Jesus Cristo, de final de ano.

P- Ah você fez dessas?

V- Fazer eu nunca fez, mas eu assisti.

P- Qual é a primeira coisa que você lembra que você viu

$\mathrm{V}$ - Eu lembro que eu pensei que era algo que eu nunca ia querer fazer na minha vida (risos). Olha eu já vi "Pé de Pilão", que uma professorinha montou.

P- Você ficou assistindo, e não participou. Isso foi a primeira coisa que você viu?

V- Não! Agora que eu tô lembrando, olha de muita coisa! Que interessante. Eu vi também... a primeira peça que eu vi... foi "Gato Malhado e a Andorinha Sinhá”. Nossa! Agora que, nossa como é que eu tinha esquecido! Isso marcou muito, foi no Municipal e minha professora tinha ido pra São Paulo e assistido. E parece que era o Grupo Silvio Santos que trouxe pra Ribeirão na época e ela queria mostrar isso pra gente no teatro. Eu tava na 3 série e ela levou a escola toda. E foi que... eu lembro que eu fiquei muito encantada. Que interessante, agora que eu 
vasculhei a minha mente que eu lembrei, eu fiquei muito encantada, era uma superprodução também. E tinha aquela magia, né um olho de criança. Eu também pensei como é difícil.

P- Você lembra de alguma imagem?

V- (rindo) Lembro de muitas, lembro que tinha muitos efeitos. Tinha uma parte que tinha uma cachoeira, que dava um blecaute, tinha um tanque que abria e era um espelho, e ele via o reflexo. Ah! E tinha no final bolinhas de sabão que saia do teto!

P- Música, você lembra?

V- Música não, mais imagem. (risos). Tá vendo como a gente tem que exercitar a mente (risos)

P- E fazendo foi o monólogo, te deram um texto...

V-Sim, no [escola de teatro] mesmo.

P- Outra pergunta: Como é que o teatro é compartilhado com amigos e família?

V- Eu tento, levar eles pra assistir peça, às vezes não dá certo, eu aprendi uma coisa que a gente tenta e às vezes não faz parte da realidade da pessoa e ela não quer, então não vamos forçar. Mas às vezes eu tento... uma pessoa que não vejo faz tempo, amiga minha, "vamo no teatro?" Quando tem "vamo assistir uma peça comigo". Ela topa e no final, como troca a gente vai pra algum outro lugar e conversa (risos). Teatro ajuda nisso também

P- Já consegui trazer amigos, pra ver peças suas?

V-Pro IRC eu já trouxe e fora, eu vou muito no SESC também. É interessante que depois que você termina a escola, você não tem contato mais com os amigos, e aí você fala " vamo no SESC!”. E é interessante, porque querendo ou não mesmo quando a pessoa não tem esse hábito de assistir, ela sempre me pergunta depois, “ah! E tal coisa?”. Eu trouxe uma amiga pra assistir uma peça, e eu nunca esperei que ela fosse ter essa reação depois da peça porque ela... ela não liga muito pra isso. E no final da peça ela foi me perguntando né, eu achei interessante o entendimento dela da peça. Ah entendi aquela parte, das câmaras de gás, do nazismo e tal. $\mathrm{Eu}$ tenho minha interpretação, às vezes a pessoa fala ah você faz o IRC e sabe, mas... eu não sei... (risos) Mas é interessante essa discussão depois. É uma coisa que talvez aproxima mas né?

P- Com a família como é que é?

V- Família?

P- Como é que é sua família...

V- Ih! é complicado (risos).

P- Você mora com quem?

V- Eu moro com a minha mãe, meus pais são separados faz tempo. 
P- Mas vocês se vêem, tem convívio? Seu pai?

V- Tenho convívio, mas não e direto assim... não tenho nada com ...

P- E mora você, sua mãe...

V-Só eu e minha mãe.

P- Seu pai mora em outra casa, tem outros filhos?

V-- Espero que não... (risos)

P- Ele lá e você aqui...

P- E com a sua mãe você comenta as coisas que você faz...

V- Então comentar é uma coisa que eu já desisti (risos). É que nem eu falei, às vezes a gente tenta mas não faz parte da realidade da pessoa, então não adianta eu ficar insistindo. Fazer o que, né. Já trouxe minha mãe pra assistir "Babel” ela gostou, mas não foi nada que mudasse a vida. Paciência.

P- Então, mas você acha que ela apoia assim você fazer teatro?

V- Eu acho que não faz diferença... Então, toda minha mudança eu percebo mais em mim, e não sei porque mas ela não veja, "nossa minha filha mudou o jeito de ser por causa do teatro", talvez ela não perceba, porque ela foi sempre um pouco distante em relação ao trabalho....

P- Ela trabalha muito... qual a profissão dela?

V- Auxiliar de laboratório. Ela sempre foi muito, só trabalho, só trabalho, só trabalho... Então nunca teve essa.

P- Vocês não conversam sobre isso?

V- Não, sobre nada relacionado a isso. Eu tenho mais isso quando eu tô aqui, mas não são todos que, que tão envolvidos mais, que vão assistir peça além... Eu não vou falar com minha vó, ela não vai entender.

P- Porque você acha que sua mãe não se interessa?

V- Não sei, talvez porque, simplesmente não é uma coisa que... a toca. Que nem quando eu senti quando eu pisei no palco a primeira vez... A gente tem uma coisa dentro da gente que... cada um tem uma... Eu acho que eu sou completamente "Humanas" ela não... é uma coisa mais lógica, uma coisa mais razão, uma coisa mais cética. No teatro tem uma coisa diferente, por isso eu relaciono um pouco com pré-escola, mais liberdade de ser... Ela é mais rígida.

P- Você acha que se você fizesse uma faculdade de teatro sua mãe te apoiaria?

V- Ela não ficaria empolgada...

P- Você já comentou com ela sobre isso?

V- Já e não faz diferença sabe? Mas parece que se eu falasse que hoje vou fazer algo que talvez ela goste ela ia ficar muito entusiasmada. Assim como ela fica, por exemplo, eu sou 
filha única, com meus primos que estão fazendo coisas completamente... um enfermeiro, outro... Às vezes eu sinto parte dela assim jogando na cara sabe? Tipo "e você não faz..." Mas eu já botei na minha cabeça que se pai e mãe não quer que filho faz isso então o azar é deles. Eles que fizesse o que eles querem que você faça. Não tem como você transferir seus sonhos seus filhos. Cada um é cada um. A Ana falou uma vez uma coisa muito interessante, que a gente não cria filho pra gente, cria filho pro mundo. Eu acho que é isso. Apesar de ser filho a gente é individuo, é individual.

P- Então se você fizer artes cênicas você...

V- Vou fazer independente de opinião...

P- Então acho que é isso, a gente terminou.

V- (rindo) Ah, tá, eu falei tudo enrolado fiquei nervosa...

P- Que isso, eu agradeço!

V- Eu que agradeço. 